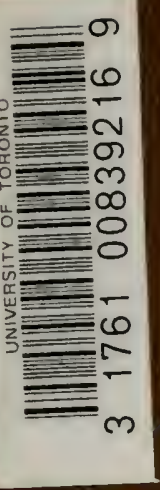

Univ. of TORONTO LIBRARY 

ZWTOTR TIST SEF : 142. 
Digitized by the Internet Archive in 2008 with funding from Microsoft Corporation 


\section{GENETIC STUDIES OF RABBITS AND RATS}

W. ${ }^{\text {E. CASTLE }}$

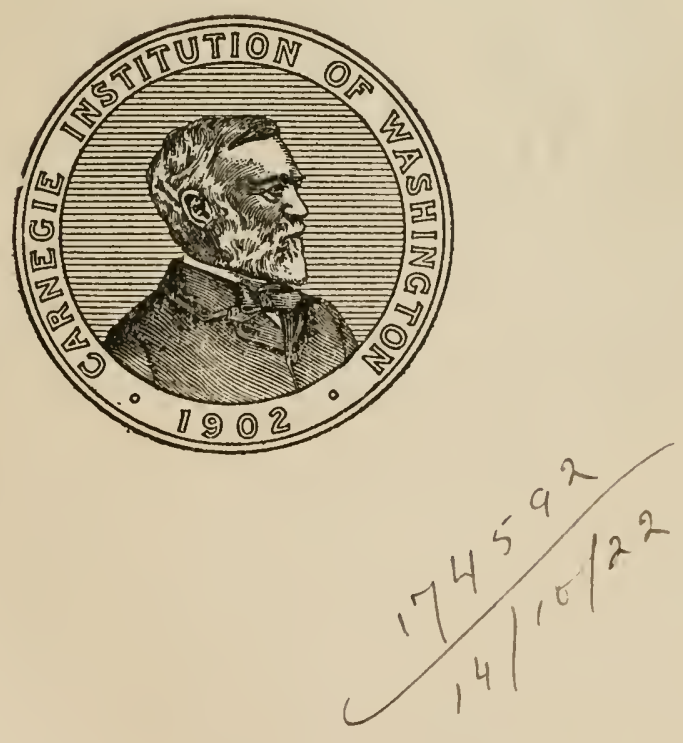

Published by the Carnegie Institution of Washington WASHINGTON, MAY, 1922 


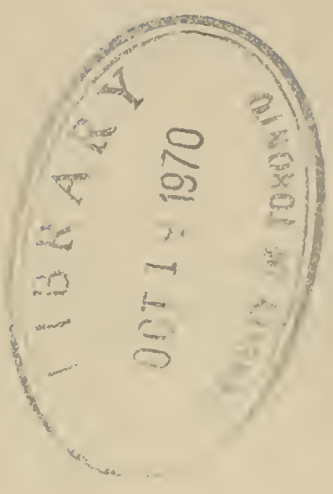

CARNEGIE INSTITUTION OF WASHINGTON

Publication No. 320

Copies of this bouk
first issyed
MAY $22192 ?$

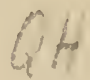

431

C 374

TECHN ICALPRESS

WASHINGTON, D, C. 


\section{GENETIC STUDIES OF RABBITS AND RA'TS.}

\section{PART I. \\ SIZE-INHERITANCE IN RABBIT CROSSES.}

In the last fifteen years numerous studies have been made of the inheritance of characters which are quantitatively variable or fluctuating. As a result of these studies it has become clear that in many cases fluctuation is due to non-genetic causes, to the environment rather than to the constitution of the germ-cells. In such cases selection is without effect in modifying the racial character. This is the accepted explanation of the negative results obtained by Johannsen in selecting beans for increased or decreased size, and of the similar results of Ewing in selecting plant-lice for altered body dimensions, and those of Jennings and others with paramecium.

But in a majority of cases variation due to genetic causes occur's in association with that due to non-genetic or environmental causes; in fact, it is possible to distinguish between the two only by the results of systematic selection. When the environment is kept constant and a race does not change in response to selection, we assume that no genetic variation is present. But if the race does change in response to selection, we have no alternative but to assume that the variation is genetic in character. Body-size in birds and mammals shows well the simultaneous yet distinct action of genetic and non-genetic agencies. The amount and quality of the food supplied to an animal limits its size, yet if food is supplied in abundance and of proper quality, some races of animals attain greater size than others. This is the result of genetic differences.

The analysis of such genetic differences is difficult. A pioneer attempt was made by Galton (1889) in his study of human stature, the inheritance of which he characterized as blending. This term was adopted by Castle et al. (1909) in describing the inheritance of ear-length and body-size in rabbits. A Mendelian interpretation of size-inheritance was later advocated by Lang (1910), based on the multiple-factor hypothesis of Nilsson-Ehle and this has now received general acceptance. Davenport (1917) has recently applied it to human stature, but has gone a step farther in assuming that the genetic factors which govern size in one part of the body are often not the same as those which govern the size of other parts.

Punnett and Bailey $(1914,1918)$ in their studies of size-inheritance in poultry and in rabbits bring forward a different hypothesis. 
They attempt to explain the results of size-crosses with the aid of genetic factors affecting the size of all parts, but relatively few in number, a different potential effect on size being assigned to each of the assumed factors.

With a view to throwing further light, if possible, on this confused situation, a renewed investigation of size-inheritance in rabbits was undertaken by me in January, 1917. To clarify the matter, it seemed desirable to obtain races as pure as possible and as unlike as possible in size, to breed each separately and study its variability and at the same time and under similar conditions to cross the same races and study the variability of the $F_{1}$ and $F_{2}$ generations of offspring. For this purpose two small races of rabbits were selected, Polish and Himalayan, and one large race, that of the Flemish Giant. Stock was obtained from exhibitors at the last previous Boston show who had been awarded prizes for the excellence of their animals in these several breeds.

In carrying out the original plan to study size-variation in the uncrossed races, I have been only partiallysuccessful, but a good series of cross-breds has been secured and studied. In the pure races (plate 1 ) the number of adult individuals studied was, Polish 23, Himalayan 8, Flemish 5. Adult cross-breds have been produced as follows: Polish $\times$ Flemish, $F_{1} 27, F_{2}$ 137; Polish $\times$ Himalayan, $\mathrm{F}_{1} 25, \mathrm{~F}_{2} 55$; Himalayan $\times$ Flemish, $\mathrm{F}_{1} 17, \mathrm{~F}_{2} 70$. The total number of adult individuals studied for size-characters in this investigation is 367. The characters studied are weight, ear-length, and the following bone measurements: (1) skull length, (2) skull width anterior to orbit, (3) skull width posterior to orbit, (4) length of femur, (5) length of tibia, (6) length of humerus.

Weights were taken at intervals of about two weeks, from the time of weaning to the attainment of full growth. As animals are apt to increase in weight through the accumulation of fat after the cessation of general growth, the adult weight of an animal is taken as the maximum weight attained under one year of age. Small races of rabbits attain maturity earlier than large ones. For example, Polish rabbits are usually full-grown at ten months of age, whereas Flemish may grow slowly after they are one year old. The skeletal measurements studied are based for the most part on animals which had attained the age of fourteen months, but some measurements have been used of younger animals, when it has been found by comparison of different measurements that full growth had probably been attained. Adult ear-length is attained much earlier than full body-size. Growth of ears is practically completed at twenty weeks of age. Accordingly, it has been possible to use the ear-measurements of animals which died before they attained full body-size, and so the totals for ear-length studies are greater than those for weight 
(which is supposed to be complete at one year) or for bonedimensions, which as a rule are based on specimens fourteen months old.

\section{GROWTH-CURVES BASED ON WEIGHT.}

Most of the rabbits were born in the spring and summer months, May to August inclusive, but some were born as late in the year as November and a few in the early part of December. None was born in the months January to March inclusive. The young were usually weaned when one month old, at which time periodical weighing of the animals was begun. It was considered very desirable to raise all the individuals born, for fear that if small-sized individuals should succumb in competition with their larger brothers and sisters, the statistical conclusions might be vitiated thereby. To this end, free use was made of foster-mothers. Young under a week old may readily be transferred from the nest of one mother to that of another. In only one case have I known a mother to refuse to care for fosterchildren substituted for her own of like age. Of course, notwithstanding all our precautions, many young rabbits died before reaching maturity, either from intestinal troubles in hot weather or from nasal troubles ("snuffles") in cold weather. But a careful study of our records indicates that there was no differential selection in favor either of large or of small rabbits in these deaths. The young rabbits were supplied with an abundance of suitable food, in summer grass and oats, in winter hay, oats, and cabbage or carrots. Occasionally a rabbit was not weaned promptly at one month of age. If, for example, an individual seemed feebler than its fellows at weaningtime, it might be left with the mother a week or two longer. Again, differences in size were often observed at weaning-time between litters of like ancestry, but of unlike number in individuals. If a doe nurses six young, they will average smaller at weaning than will young of similar ancestry nursed by two mothers, each of which divides her milk among three young. Fanciers believe that this affects the ultimate size of the offspring. They think that the largest rabbits are obtained by rearing only two or three young to a litter and by allowing these to nurse the mother for six weeks or two months. Our observations do not support this view, but indicate that the ultimate size attained is influenced very little, if at all, by the size of the young at weaning, provided they are in good health and growing condition and are thereafter fed abundantly.

Figure 1 illustrates the matter well. Rabbits 2650 and 2834 were half-brothers. They had the same pure Flemish father and their mothers were of the same pure Polish stock. Rabbit 2650 was weaned at 29 days of age and grew slowly until he was 71 days old, when he weighed 600 grams. Rabbit 2834 was raised by a foster- 
mother alone, receiving all her milk until he was weaned at 71 days old, when he weighed 1,530 grams, more than 2.5 times as much as his half-brother at the same age. Notwithstanding this handicap in his favor, he was overtaken in size by his early-weaned halfbrother at age 194 days, and was surpassed by him in adult weight by about 150 grams. The bone dimensions of the two rabbits were very similar, with a slight but probably not significant superiority in favor of the late-weaned individual. In the case of neither rabbit does the growth-curve show any interruption of healthy growth. The form of the growth-curve is affected by the superior nutrition of 2834 during his first 2 months, but the ultimate size attained is not influenced thereby.

Figure 1 also shows the growth-curve of a third rabbit (2578), half-brother to each of the others (2650 and 2834). He was born

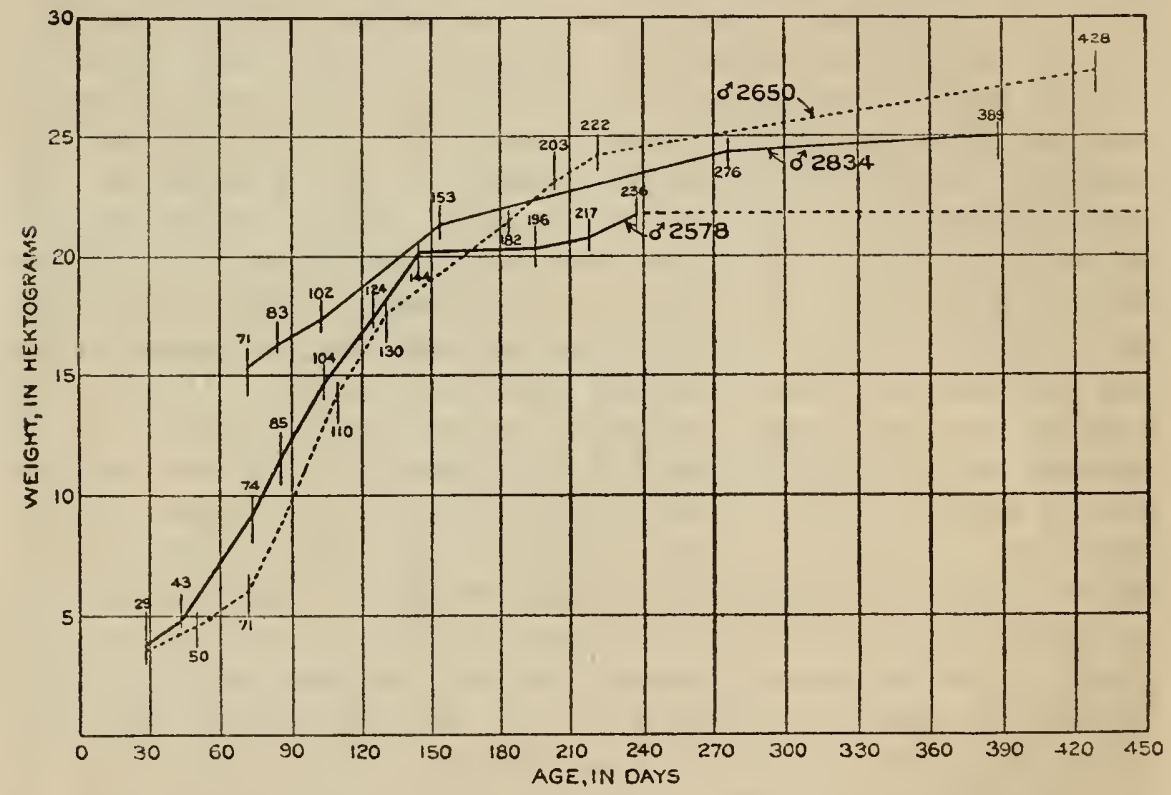

FIG. 1.-Growth-curves in weight of three $F_{1}$ rabbits which were half-brothers, all having the same pure Flemish sire but each having a different pure Polish mother. Male 2578 was born July 26, 1917 ; male 2650 was born August 9, 1917 ; male 2834 was born December 7,1917 . Note that the rabbit which was largest as an adult (2650) was smallest up to $\mathbf{1 5 0}$ days of age, whereas the rabbit (2834) which was much the heaviest as a young rabbit because he received all the milk of a foster-mother up to weaning at 71 days of age, nevertheless fell below 2650 in adult weight.

just two weeks earlier than 2650 , was weaned at the same age (29 days), but was slightly heavier at weaning and held the lead up to age 144 days, when he was practically full-grown. His ears were then of maximum length, 10.4 centimeters. On the same day (December 17) the younger rabbit (2650), although lighter in 
weight, had longer ears (10.9 centimeters), a fact which foreshadows his greater adult size. He kept on growing after passing age 144 days and ultimately became much heavier. His bone-measurements were also greater, except in one instance, femur-length, which was practically the same. In the case of this pair of half-brothers, the environmental conditions were substantially identical. They were born within a fortnight of each other, weaned at the same age. and grew up under the same seasonal conditions on similar food, yet they diverged in adult weight, bone-measurements, and ear-length more than the pair (2650 and 2834) which had such different environmental conditions.

From facts such as these, it is believed that accidental differences in environment (though we have striven to avoid them) have little to do with the size-differences observed among our rabbits. On the other hand, it is clear that our purest races of rabbits are not perfectly homogeneous genetically as regards size, since with the most carefully controlled environment size-differences occur.

Figure 2 shows the growth-curves of two female rabbits, 3099 and 3100 , litter mates borne by the same pure Himalayan mother to the

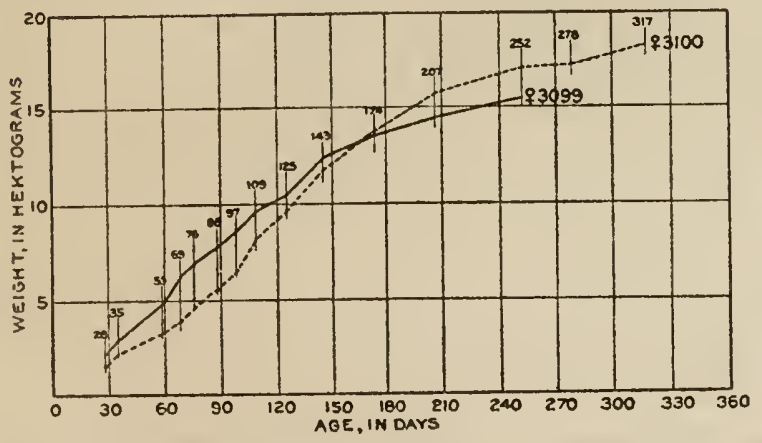

Fig. 2.-Growth-curves of two $F_{1}$ rabbits, litter-mates borne by the same pure Himalayan mother to the same pure Polish sire, and kept together in the same pen throughout their growing-period. Note difference in character of the growth-curves. The rabbit which was larger at weaning. matures earlier and remains smaller as an adult.

same pure Polish sire. Both were weaned on the same day at the age 28 days. They were kept together in the same pen during subsequent growth. At birth, 3099 was the larger of the two sisters and maintained her superiority for about four months, when her growth-rate began to slow up, while that of her sister, 3100, kept on steadily. At about the age 170 days the originally smaller rabbit surpassed her sister in size and held this relative position thereafter. In every bone measurement she was a little larger than her sister, but in ear-length they differed little, the smaller rabbit being credited with having slightly longer ears.

From the weight-records made for each rabbit it is possible to construct a growth-curve, as in the cases just discussed. Such curves have been plotted for each pure-bred and each $\mathrm{F}_{1}$ cross-bred 
rabbit raised. From these curves, readings have been taken giving the approximate weight of the individual at the ages of $30,40,60$ days, and so on, at 30 -day intervals, to the age 360 days. Combining the weight records for each group of individuals, an average growthcurve is obtained for the group, as shown in figure 3.

In this figure it is indicated that Polish rabbits are small at 30 days of age, but grow with fair rapidity until about 180 days old. Then the growth-rate declines and growth is practically ended at the age 210 days. In many cases the weight actually decreases again after attaining a maximum at sexual maturity, or shortly thereafter, as Punnett (1918) has observed. But such decline is not invariable, and it may result from a variety of causes, such as less nutritious

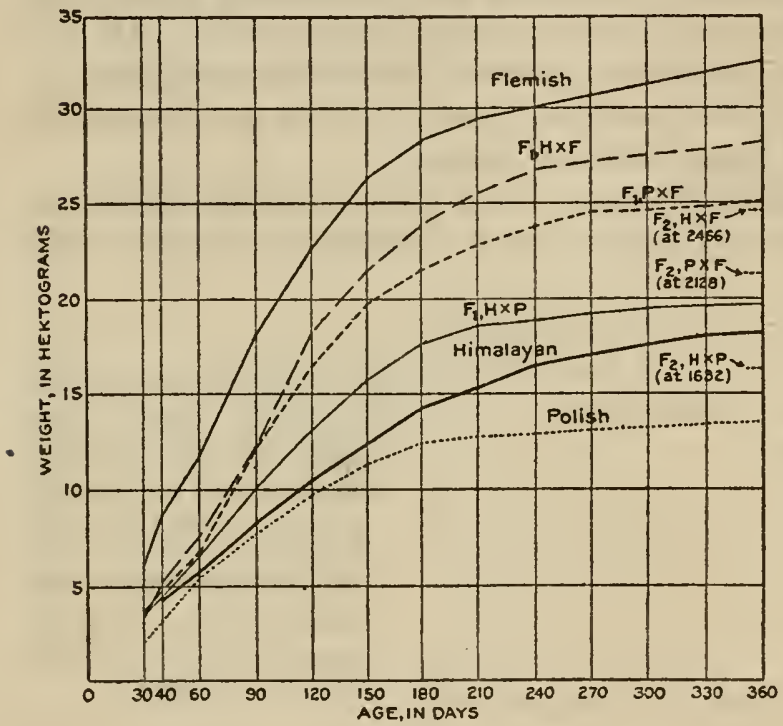

FIG. 3.-Growth-curves of the three races of rabbits, Polish, Himalayan, and Flemish, and of the groups of $F_{1}$ hybrids obtained by crossing the three pure races. The average adult weight of each group of $\mathrm{F}_{2}$ hybrids is shown for comparison with $\mathrm{F}_{1}$, below which it falls in every case.

food, a cold, or lactation (in females). When normal conditions are restored, the weight usually rises again and subsequent accumulations of fat usually carry the final weight above the puberty maximum. In plotting the growth-curves the maximum weight attained in the first year is considered as persisting thereafter. This will account for the fact that the plotted average curves do not show any decline, even though the weight-curves of individuals would in many cases do so. The rabbits that show increases in weight, due largely to fattening subsequent to puberty (180 to 210 days), will explain the fact that the weight-curve continues to rise until the end of the period plotted, 360 days.

In the case of Himalayan and Flemish rabbits, the weight at the age 30 days is greater than that of Polish rabbits. The growth-rate is also greater, so that the growth-curves continue to diverge more and more, one from another. The slowing up of growth at puberty 
(180 to 210 days) is also less abrupt and the increase in weight subsequent to puberty is greater. The average weight at 360 days of Polish rabbits of both sexes is less than 1,400 grams, for Himalayan rabbits it is 1,800 grams, and for Flemish it is over 3,200 grams.

In Polish rabbits, as compared with other and larger breeds, the initial weight is less, the growth-rate less, and the completion of growth comes earlier. All these phases of growth combine to make the ultimate weight smaller. Comparison of the growth-curves of Polish and Flemish brings this point out very clearly. The Flemish curve is far above the Polish curve at the outset and diverges from it increasingly up to the age 360 days. The Himalayan growth curve lies everywhere between the Polish and Flemish curves, but is much nearer to the Polish. In form, however, it is more like the Flemish curve, in that growth continues longer after puberty.

$F_{1}$ rabbits produced by crossing Polish with Himalayan have a greater initial weight than either pure parent race and grow faster. At puberty (180 to 210 days) the $F_{1}$ rabbits surpass Polish by over 500 grams. They are more than 40 per cent heavier. As compared with Himalayans of like age, they are more than 20 per cent heavier. At age 360 days, the $F_{1}$ rabbits are 45 per cent heavier than Polish, but only 9 per cent heavier than Himalayan, since the slower-growing Himalayans have lessened the superiority which the $F_{1}$ rabbits showed at puberty, but have not extinguished it.

$F_{2}$ rabbits from this cross, obtained by mating the $F_{1}$ rabbits, brother with sister or half-sister, show an average adult weight of 1,632 grams, which is intermediate between the adult weight of Polish and Himalayan rabbits, the races originally crossed, being 20 per cent heavier than Polish and 10 per cent lighter than Himalayan. The superiority in size of the $F_{1}$ animals is a purely $F_{1}$ phenomenon, as we shall see. It never persists into the $\mathrm{F}_{2}$ generation. Its existence is nevertheless an important practical consideration, which makes grading and the crossing of breeds highly advantageous under certain circumstances.

In the cross of Polish with Flemish rabbits, $F_{1}$ is in size well above the intermediate between the parent races, another illustration of $F_{1}$ vigor, although in this case $F_{1}$ does not surpass the larger race in size. The form of the growth-curve is also intermediate. Maturity is attained early, as in the Polish race, but the practical cessation of growth comes later than in the Polish race, at 240 days rather than at 200. The adult weight of the $F_{1}$ rabbits, at the age 360 days, averaged 2,539 grams, as compared with 3,240 for Flemish and 1,359 for Polish. The intermediate would be 2,300 grams, which the $\mathrm{F}_{1}$ group surpasses by more than 10 per cent. In the HimalayanPolish cross, $F_{1}$ surpassed the intermediate by over 20 per cent, and $F_{2}$ surpassed it by 3 per cent. 
In the Flemish-Polish cross, as in the Himalayan-Polish cross, $F_{2}$ falls below $F_{1}$ in size. It is found to be 2,128 grams as compared with 2,539 for $F_{1}$. It is even less than the intermediate, 2,300 grams, by about 8 per cent.

In the Flemish-Himalayan cross, the growth-curve for $F_{1}$ is very similar in form to the curve for pure Flemish. There is a gradual falling in the growth-rate at about 210 days, which indicates the usual slowing-up influence of puberty, coming about a month later than in Polish rabbits. But growth continues even after this retarding influence sets in, just as it does in Flemish rabbits. The weight at 360 days is 2,781 grams as compared with a strict intermediate between the parent races of 2,523 grams, which it surpasses by 10 per cent, about the same relation found in the Polish-Flemish cross. Again $F_{2}$ shows a falling off as compared with $F_{1}$ to 2,466 grams, which is 2 per cent less than the intermediate.

To summarize the foregoing observations:

(1) In races of small-sized rabbits the initial weight is small, the growth-rate is low, and growth terminates early. Conversely, rabbits of large-sized races have a large initial weight and growth energy, which not only makes them grow faster, but also makes them grow a longer time than do rabbits of small-sized races.

(2) When races of small rabbits are crossed with a race of large rabbits, the initial weight, growth energy, and duration of growth are all intermediate in character, but are greater than the strict intermediate in the $F_{1}$ generation and approximate it or fall slightly below it in $\mathrm{F}_{2}$.

(3) When two races of rabbits (such as Polish and Himalayan) are crossed, which do not differ greatly in size, $F_{1}$ may surpass either parental race in vigor of growth, though not in duration of growth. Consequently the maximum advantage in size of $F_{1}$ over the parent races will be attained at puberty. $\quad F_{2}$ will approximate the intermediate in size between the parent races originally crossed.

\section{WEIGHT AND SEX.}

In the foregoing pages the average weight of groups of individuals has been under discussion without reference to individual variation within each group or the effect of crossing on such variation, or the relation of weight to sex. In any discussion of the inheritance of weight, these questions must be taken into consideration. First let us consider the relation of weight to sex. The "standards" of the various breeds of rabbits formulated by breeders in England and the United States make no specification as to the relative sizes of the two sexes in the small breeds of rabbits, but in the large breeds they regularly specify a larger size for females than for males. Thus, the English standard for the variety Steel Gray Flemish Giant 
(plate 1, F) specifies "Bucks shall be not less than 11 pounds and does not less than 13 pounds." An American publication gives the standard weight for Japanese rabbits as "bucks 7 pounds, does 8 pounds," that of French Silvers as "bucks, 9 pounds; does, 10 pounds or over."

The existence of such specifications in breed standards implies that, at least in large races of rabbits, the female either is naturally larger than the male of like genetic constitution, except as to sex, or else that the breeders have some expectation of making it so.

The relative weight of the two sexes in the groups of rabbits which I have studied is shown in table 2. In the Polish breed, males were found to be slightly heavier than females. The single male Himalayan studied differed very little from the average of the 5 females; but in the cross-bred rabbits of all three combinations, viz, Polish-Himalayan, Polish-Flemish, and Himalayan-Flemish, females were heavier by from 50 to 200 grams ( 2.5 to 7.5 per cent) than were males derived from the same cross. It seems clear, therefore, that the breed standards are correct in recognizing the greater weight of females than of males, at least in the heavier breeds of rabbits. The difference is a natural one, not arbitrary, but the amount of the difference has probably been exaggerated in the standards, which call for a difference of about 15 per cent. This is double the greatest difference observed by me.

\section{INHERITANCE OF WEIGHT.}

Individual variation in weight can best be studied by statistical methods. Maximal first-year weight will be dealt with, except in the few cases of rabbits received as adults. For the present, the slight difference in size of the two sexes will be disregarded. The general character of the variation in weight is presented graphically in figures 4 to 6 . The data on which these graphs are based will be found in table 3 .

Figure 4 shows that the modal weight of Polish rabbits is about 1,400 grams, while Himalayan rabbits are about 400 or 500 grams heavier. The $F_{1}$ cross-breds are heavier than either pure race, as shown also in the growth-curves (fig. 3 ). They vary symmetrically around the class whose center is 1,949 grams, designated class 19 in figure 4 . The

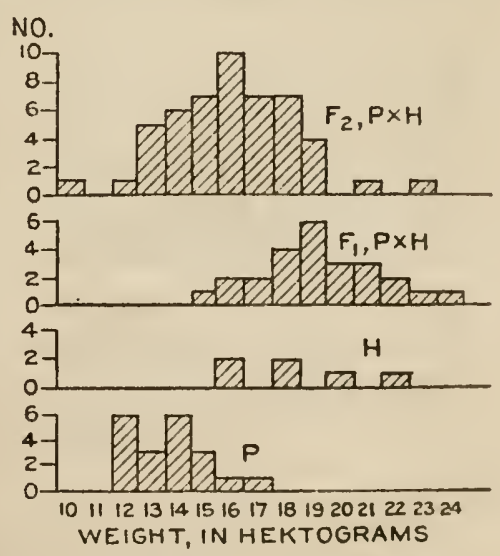

FIg. 4.-Polygons showing variation in weight of pure Polish $(P)$ and pure Himalayan $(H)$ rabbits, and of their $F_{1}$ and $F_{2}$ hybrid ofispring. $\mathrm{F}_{2}$ generation, which contained just twice as many individuals as 
$F_{1}$, varies about class 16 as a mode, being about 300 grams lighter in average weight than the $F_{1}$ groups. The variability of this group as measured by the standard deviation is only slightly greater than that of $F_{1}$, being 233 grams as compared with 218 grams for $F_{1}$.

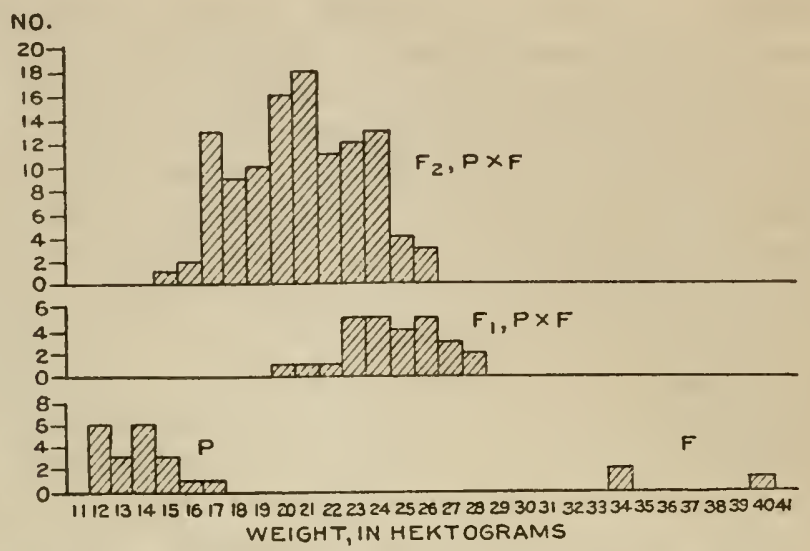

Fro. 5.-Polygons showing variation in weight of pure Polish $(P)$ and pure Flemish $(F)$ rabbits, and of their $F_{1}$ and $F_{2}$ hybrid offspring.

Figure 5 shows the effect upon weight of the widest of the three crosses, that between Polish and Flemish. The parental groups are separated by over twenty classes. $F_{1}$ lies midway between them, its mean falling in class 25 . The variation polygon is rather flat and wide, which would seem to indicate lack of complete genetic uniformity in one or both parent races.

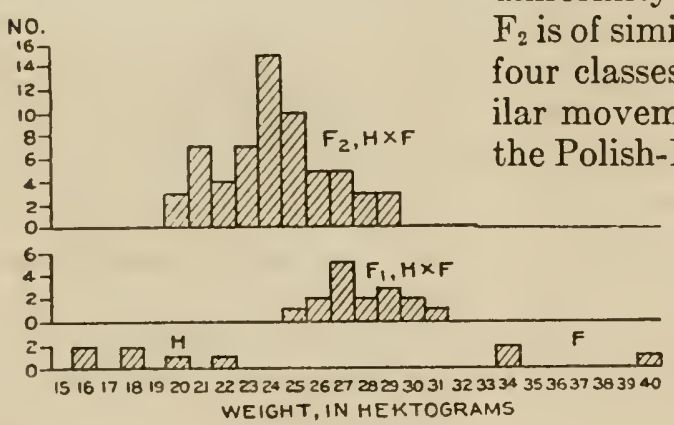

Fra. 6.-Polygons showing variation in weight of pure Himalayan $(H)$ and pure Flemish $(F)$ rabbits, and of their $F_{1}$ and $F_{2}$ hybrid offspring.
$\mathrm{F}_{1}$ and the $\mathrm{F}_{2}$ generations. The variability, as measured by the standard deviation, has increased by about 25 per cent, from 198 grams in $\mathrm{F}_{1}$ to 257 grams in $\mathrm{F}_{2}$.

Figure 6 shows for the Himalayan-Flemish cross the variability in

weight of $F_{1}$ and $F_{2} . \quad F_{1}$ is strictly intermediate between the parental races. Its mode lies in class 27 , but the average is somewhat higher, being 2,827 grams (table 3 ). The mode of $F_{2}$ lies three classes 
lower in class 24 , the mean being 2,472 or about three and a half classes lower than $F_{1}$. The variability of $F_{2}$ is about 40 per cent greater than that of $F_{1}$, being 230 grams instead of 162 .

In neither of the Flemish crosses does the $F_{2}$ variation extend upward into the range of pure Flemish, but is separated from it by from four to seven vacant classes. In other words, the larger parental type is not recovered in $\mathrm{F}_{2}$, doubtless because the number of independent genetic factors involved is too great. If the larger parental type is not recovered, it is not to be expected that the smaller type would be recovered, since this would involve a chance recombination of factors equally improbable of realization in a limited number of offspring; but in reality the $\mathrm{F}_{2}$ range does in every case extend downward into the range of the smaller parent type; therefore either the smaller type is more readily recovered, or what appears to be the smaller type recovered in $\mathrm{F}_{2}$ is really not such, but is a new genetic combination or combinations which resemble in gross weight the original parental type. The latter alternative seems more probable. This view is supported by the observations on ear-length, which character is closely correlated with weight, and yet in regard to which neither the small.nor the large parental type is recovered in $\mathrm{F}_{2}$, all $\mathrm{F}_{2}$ variates occurring in the intermediate region.

\section{EAR-LENGTH.}

Ear-length is a character easier to study than body-weight, because the adult condition is attained earlier and the races studied are more sharply distinguished as to ear-length than as to weight. The ears, as a rule, have attained their full growth at the age 150 days, or even earlier in the case of the Polish race, whereas the weight continues to increase slowly after that age.

The ear-length was recorded at the same time that the rabbits were weighed, though less frequently, as little change was noted in the ear-length after the age 150 days. After a rabbit had attained that age his ears were measured merely often enough to make sure that no further change had occurred and that the earlier measurements had been accurate. A variation of 1 or 2 millimeters was frequently noted in the measurements, and the final rating of each rabbit was accordingly based on the approximate mean of the recorded measurements. The measurement taken was read from a ruler placed between the base of the right ear and the head, the ear being then held vertically against the ruler and slightly stretched and the reading made at the ear-tip. Small races of rabbits have short ears; large races have both longer ears and longer skulls, as we shall see.

The variation in ear-length of the groups of rabbits studied is shown graphically in figure 7 . The Polish rabbits studied range 
in ear-length from 81 to 88 millimeters, Himalayan from 92 to 97 millimeters or about 1 centimeter longer-eared than Polish, while the three Flemish individuals used as parents, notwithstanding their diversities in weight, are remarkably uniform in ear-length, ranging from 143 to 147 millimeters, or about 6 centimeters greater than Polish and 5 centimeters greater than Himalayan. The three races are very distinct and each by itself very uniform.

The data on the ear-length of the cross-bred rabbits is summarized in table 4 and is shown graphically in figure 7 .

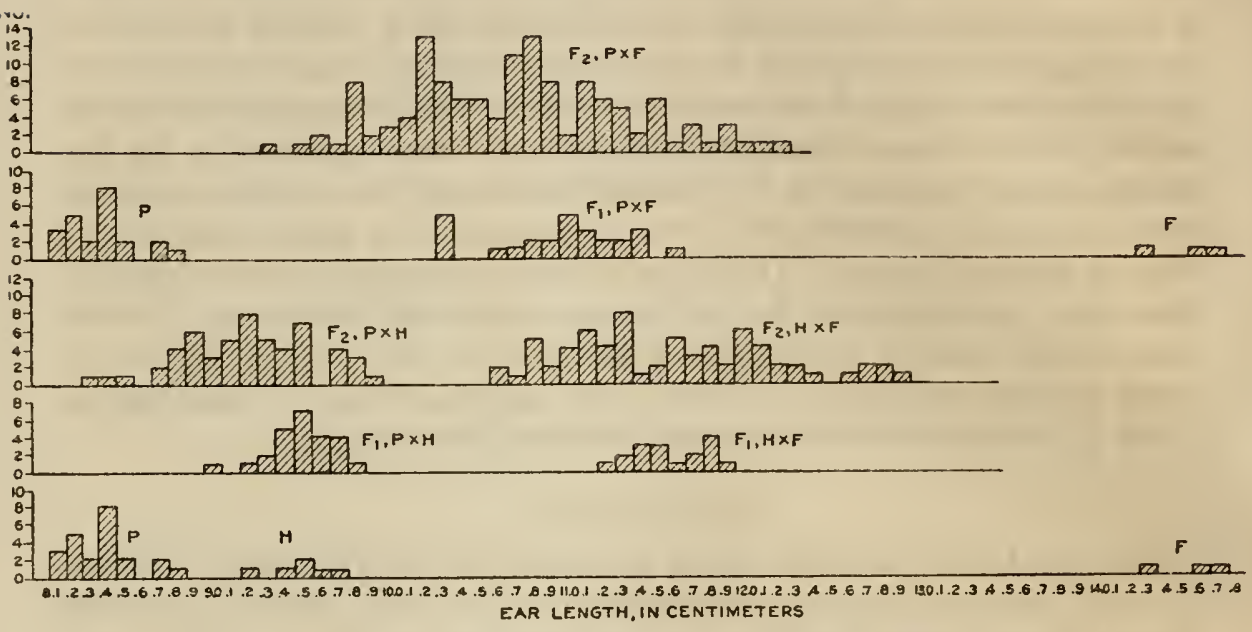

FIG. 7.-Polygons showing variation in ear-length of the three pure races of rabbits and of their $F_{1}$ and $F_{2}$ hybrid off spring.

In the cross between the Polish and Himalayan breeds, which differ in ear-length by about 10 millimeters, long ear appears to be completely dominant. Variation is about the mode of the Himalayan race and the average is practically the same (94.8 in the Himalayan, 94.9 in the $\mathrm{F}_{1}$ group). But in $\mathrm{F}_{2}$ the variation is much greater and the range extends downward so as to include the mode of the Polish race as well as upward to cover the entire range of the Himalayan race and of $\mathrm{F}_{1}$.

The cross of Himalayan with Flemish gives results which are easier to interpret. These two races considered singly are very uniform in ear-length. Each varies closely about a mode widely separated from that of the other race (see fig. 7). $\quad F_{1}$ is about 4 or 5 millimeters below the intermediate and varies little. $F_{2}$ has the same relation to the intermediate, with practically the same mean, but is much more variable, the standard deviation (table 4 ) having risen from 2.08 millimeters in $F_{1}$ to 5.85 millimeters in $F_{2}$, and the range from 8 millimeters to 24 millimeters. Nevertheless, the range of $F_{2}$ does not 
extend into the range of either parental race. A gap of 8 millimeters separates the shortest-eared $\mathrm{F}_{2}$ from the longest-eared Himalayan rabbit, and a gap of 13 millimeters separates the longest-eared $\mathrm{F}_{2}$ from the shortest-eared Flemish. Hence it is clear that neither parental combination is recovered in the total of $70 \mathrm{~F}_{2}$ individuals studied. Clearly, many independent factors must differentiate the parent races as regards ear-length.

The cross of Polish with Flemish is a still wider one than that just described and $F_{1}$ is somewhat less uniform. It is, indeed, about as variable as the $\mathrm{F}_{2}$ obtained from the Himalayan-Flemish cross, which fact indicates a greater genetic variability in the Polish than in the Himalayan race as regards ear-length. Again, in this cross $\mathrm{F}_{1}$ falls below the intermediate between the means of the parent races by about 5 millimeters. $F_{2}$ shows greatly increased variability as compared with $F_{1}$. The range has risen from 14 to 30 millimeters, and the standard deviation from 3.76 to 6.05 millimeters (see table 4). Nevertheless, the range of $\mathrm{F}_{2}$ does not extend into that of either parental race. Four vacant classes separate it from the range of pure Polish and 20 vacant classes separate it from the range of pure Flemish. It accordingly approaches the smaller race more nearly than the large one (as in weight), but neither parental condition reappears in $\mathrm{F}_{2}$, although this consists of 131 individuals. Again we are forced to conclude that. numerous independent genetic factors affecting ear-length differentiate the parent races.

The question may be raised whether there is a difference between the sexes as regards ear-length, as there appears to be in regard to weight. Table 5 answers this question in the negative. The sexes differ very little in ear-length and neither is consistently greater than the other throughout the groups.

\section{BONE MEASUREMENTS.}

The length of the skull has been measured, in these studies, from the notch in the ventral margin of the occipital foramen to the anterior surface of the incisor teeth in a straight line, measurement being made with a caliper rule and readings taken in tenths of millimeters. Differences in skull-length between the races of rabbits studied are less in amount than those which distinguish these same races as regards ear-length. But it is desirable to ascertain whether skull-length differences are inherited in a similar way and whether they are correlated with differences in ear-length and body-weight. Hence the study of skull-length will have value, even though its results are not as clear-cut as those derived from other studies.

Polish rabbits have a skull-length of from 63 to 69 millimeters. Himalayan rabbits have somewhat longer skulls, ranging from 66 
to 72.5 millimeters. The skull-lengths of 5 Flemish rabbits studied range from 82.5 to 88 millimeters (see table 6).

The cross between Polish and Himalayan rabbits produced offspring surpassing both parent races in skull-length, as in body-weight, a manifestation, no doubt, of heterosis or cross-bred vigor. The $\mathrm{F}_{1}$ averaged 70.2 millimeters in skull-length, the larger parent race averaging 68.9 millimeters, the intermediate between the parents being 67.3 millimeters. The average skull-length of $F_{2}$ in this cross was exactly equal to that of the larger parent. It would seem that the pure Polish and Himalayan races may have been below their genetic possibilities in skull-length, owing perhaps to inbreeding.

The Himalayan-Flemish cross (table $6, F_{1}, H . \times F$.) produced $F_{1}$ animals averaging a little larger than the intermediate between the parent races, and $F_{2}$ animals averaging a little less. But the $F_{2}$ animals were more variable than the $F_{1}$ animals, their standard deviation in skull-length being 2.85 millimeters as compared with 1.79 millimeters for $F_{1}$. The Polish-Flemish cross produced an $F_{1}$ generation close to the intermediate between the parent races as regards skull-length, but $F_{2}$ fell more than 2 millimeters below the intermediate. Again $\mathrm{F}_{2}$ was more variable than $\mathrm{F}_{1}$, the standard deviations being 3.15 and 1.18 respectively.

Tables 7 and 8 show the variation of the several groups of rabbits in skull-width measurements taken anteriorly and posteriorly respectively to the orbit. It appears that Polish rabbits, though weighing less than Himalayan rabbits and having shorter skulls, nevertheless have skulls slightly broader. The $F_{1}$ rabbits from the Polish-Himalayan cross have skulls broader than those of either parent (as well as longer, see table 6), and this superiority is retained in part in the $\mathrm{F}_{2}$ generation. These statements apply both to the anterior and to the posterior skull-width measurements. Although the Polish rabbits have slightly broader skulls than the Himalayans, nevertheless they do not transmit as much skull-width in crosses with Flemish as do the Himalayans, for in every case the skull-width of the Himalayan-Flemish cross-breds is slightly greater than that of the Polish-Flemish cross-breds. The explanation probably is that the Himalayans transmit greater general body-size (weight) in crosses with Flemish than the Polish do. Skull-width is sufficiently involved in the general increase of all bodily dimensions to more than offset the specific tendency of Polish to transmit a broad skull; for in skull-length (table 6), the Himalayan-Flemish cross-breds exceed the Polish-Flemish cross-breds even more than in skull-width.

The amount of variability in skull-width, as indicated by the standard deviation (tables 7 and 8), is too erratic to have any particular significance. $\quad F_{2}$ is not uniformly more variable than $F_{1}$ in these cases. 
In studying bone-measurements, the length of 3 leg-bones has been investigated, that of the tibia, the femur, and the humerus (tables 9 to 11). The bones measured are from the right side of the body. The results are very similar in all three cases. The Polish-Himalayan cross is followed by such increase in vigor that the cross-breds of both the $F_{1}$ and the $F_{2}$ generations surpass in bone-dimensions the intermediate between the parent breeds, but the Flemish crosses produce offspring which even in $F_{1}$ fall slightly below the intermediate between the parent breeds, and in $F_{2}$ fall below it still more. In every case $F_{2}$ is more variable than $F_{1}$.

\section{CORRELATION.}

The question may properly be raised whether the same genetic factors affecting size operate in all parts of the body, or whether there are special factors affecting the size of each part. The latter view is favored by Davenport in his studies of human stature; the former seemed to me to be indicated in the statistics of rabbit measurements published by MacDowell (1914). Wright (1918), from a statistical analysis of the same data, concludes that both general and special factors are indicated. The present investigation should be able to throw further light on the subject. If two parts or dimensions of the body are influenced by the same genetic agencies, they should vary in unison, as the genetic agencies are made to vary by means of cross-breeding. If they are influenced by different genetic agencies, they should vary independently of each other. For this reason it is desirable to study the correlation existing between each pair of size-characters studied.

The results of such a study are contained in the correlation tables (tables 12 to 29). These show strong correlation in every case between size of the body as a whole and size of each of its parts, as well as between different parts of the body. Most of the correlation coefficients (table 30 ) lie between 0.80 and 0.90 , where 1.00 would indicate complete identity of all agencies affecting size, whether genetic or non-genetic. The highest correlations are found in comparing the lengths of the long bones of the legs, humerus with femur (0.906) and with tibia (0.904), and femur with tibia (0.927). Next in closeness of correlation comes the relation between skull-length and the length of the leg-bones $(0.806$ to 0.871$)$, but the correlations of weight with bone-measurements are almost as close $(0.820$ to 0.852 ), except in the case of the tibia, where the coefficient falls to 0.758 . There is a very similar range in the correlation coefficients between ear-lengths and weight $(0.836)$ and ear-length and the various bone-measurements $(0.823$ to 0.836$)$, except again in relation to the femur, where occurs the lowest correlation of the entire 15 studied, viz, 0.741 . 
In the case of MacDowell's observations (Castle, 1914), correlation coefficients were obtained somewhat lower than those here recorded, but still notably high. The leg-bone correlation coefficients (the highest of any in both sets of observations) were in MacDowell's rabbits $0.858,0.857$, and 0.791 , where the present observations give $0.927,0.906$, and 0.904 . The skull-length correlation with tibia was, in the former case, 0.701 , in the latter 0.806 . In general, the correlations run about 10 per cent higher in the present set of observations, which is probably due to the greater range of variation in size in the lot of rabbits on which these observations have been made. The number of rabbits studied in the two cases is comparable, a maximum of 376 in the case of MacDowell's rabbits, of 348 in the present case. But the range of size-differences is greater in the present case. For example, the tibia classes in MacDowell's rabbits range from 88 to 110 millimeters; the range in the present lot is from 80 to 112 millimeters. The correlation is strongest where the range is most extended, for at the ends of the range, where only individuals of pure race occur, genetic differences are greatest and non-genetic agencies sink into insignificance, whereas at the middle of the range non-genetic agencies exert a relatively greater influence.

That this is so can be shown by a fuller analysis of one of the correlation tables. Let us take, for example, the correlation between femur and humerus (table 24). The correlation coefficient $(r)$ for all the rabbits (343) taken collectively is 0.906 . For the pure races only (table 25) it is 0.980 , almost perfect correlation, indicating nothing but genetic agencies at work. For the $F_{1}$ cross-breds (table 26), which should be no more variable than the more variable of the parent races, $r$ is 0.888 , much lower than for the pure races, because now only intermediate forms are present, the extremes represented by the pure parent races not being present. For $\mathrm{F}_{2}$ by itself (table $27), r$ is 0.878 , very nearly the same as for $F_{1}$, it will be observed, although the genetic diversity is greater. For $\mathrm{F}_{2}$ is more variable than $\mathrm{F}_{1}$ as regards both femur and humerus, yet the correlation indicated is practically the same, the difference being no greater than the probable error. If there were independent inheritance of factors affecting the size of femur and of humerus respectively, the correlation should be less close in $F_{2}$ than in $F_{1}$ because of recombination of independent genetic factors, but such is not the case. Hence we are forced to conclude that exactly the same gonetic agencies affect the size of femur and humerus. Similar reasoning would lead to the conclusion that the same is true of all size features studied, including not only bone-dimensions, but also weight and ear-length. 


\section{GENERAL OR LOCAL SIZE FACTORS.}

In the light of these facts, what should be our attitude toward the view (expressed by some students of human heredity) that mixed races are likely to contain individuals with physical maladjustments and disharmonies? On this view it is assumed that there are independent genetic determiners affecting the size of the different parts of the body. If so, when races of different size are crossed, recombination of genetic factors will in later generations produce some parts larger, others smaller, than the general average of the races crossed. This will result in disharmonic combinations, as, for example, hearts too large or alimentary tracts too short for the bodies in which they are found. Is there any real ground for such apprehension? I think not. There is in health a perfect correlation in size of each part with every other part of the same body and with the size of the body as a whole. The modern sciences of embryology and physiology tell us why this is so. It is (1) because development of the individual from the fertilized egg is so largely epigenetic, each stage growing out of its immediate predecessor; and (2) because it is so largely controlled by internal secretions.

The view of the genetic independence in size of the various parts of the body is a sporadic relapse into preformationism, such as was perhaps excusable to the Grecian mind when, without the control of observational or experimental science, it fancied animals to arise by chance coming together of arms, legs, and other parts which originally floated free and unconnected in primordial slime. The day for such preposterous ideas is past. There may be valid reasons why mixing of the more distinct human races should not be advocated, reasons perhaps sociological, but there need be no fear that an animal organism will result whose parts are not properly coördinated. We are only beginning to understand the mechanism of such coördination, through studies of the ductless glands, but it is already clear that such coördination and control are very complete and are adequate for the production of harmonic organisms in the widest racial crossing possible in the animal kingdom.

I think that a strong probability has been established that the genetic factors which affect size in mammals are general in their action, exclusively so. In this last particular I dissent from the view expressed by Wright (1918) who, from a statistical examination of MacDowell's data, concluded that the genetic factors indicated were in minor part special and local in action. Davenport has advocated a similar view concerning the inheritance of human stature, but on grounds which appear to me to be inadequate for two reasons: first, because of the imperfect character of his data, and secondly because of unwarranted deductions from them. Measurements of the several elements of human stature made on the living subject 
are far from being precise and consequently correlations between these measurements are unreliable. Yet such is Davenport's entire material. He resolves the total stature (standing height) into four elements, only two of which are capable of direct measurement, viz, the "fibula" and the "torso." The first element of the total stature is the "fibula," which is the "height of fibula head (attachment of external lateral ligament) from the floor." The second element, the "femur," is obtained by subtracting from the standing height, first the "fibula," and then the "sitting height." The third element, the "torso," is obtained by a measurement from chair-bottom to upper end of sternum, and is likely to be vitiated (as is the sittingheight) by amount of flesh or fat or clothing on buttocks. The fourth element, the "head and neck," is arrived at by subtracting "torso" from "sitting height." There are altogether too many chances of error or inaccuracy in these measurements to make them comparable in reliability with measurements made on the actual skeletal elements of individuals.

Davenport argues for the independent inheritance of the four elements of stature on the ground that races and families have characteristically different proportions of the total stature formed by each of its elements. In support of this view he figures (from "Martin, 1914") side by side photographs of a "Dinka negro" and a "Chiriguan Indian." The enlargement of these pictures is arranged so as to make the individuals of seemingly the same total height, whereby their difference in proportions is obvious. The limbs of the negro are seen to be relatively long, those of the Indian relatively short. If, now, each is a fair representative of his race, we must conclude that Dinka negroes inherit as a racial character limbs relatively long, while Chiriguan Indians inherit as a racial character limbs relatively short. But a comparison of the pictures shows also that the Indian stands much nearer the observer than the negro, as the size of his head, eyes, hands, and feet and the diameter of leg and arm are much greater. It is his nearness to the observer that makes him appear as tall as the negro in the picture. He is accordingly of absolutely short stature, whereas the negro is of absolutely tall stature. The absolutely tall individual (and race) accordingly has relatively long limbs, the absolutely short individual (and race) has relatively short limbs. Is this association accidental? If not, we may be dealing here with one racial difference, not two.

Tall stature and relatively long limbs may be due to one and the same genetic cause, and not be independently inheritable. Davenport's own paper indicates that this is probably true. He reproduces another figure (fig. 8) from "Martin, 1914," in which it is shown by diagrams that the proportions of the human body change in the lifetime of the individual, the limbs becoming relatively longer 
as the absolute stature increases. There is the same difference in proportions between boy and man as between Chiriguan Indian and Dinka negro. The inheritance of boy and man is the same; one is a further development of the other.

May it not be that tall and short human races are the result of interruptions at different stages of the general growth process? If so, races or families with "relatively long fibula" will be such simply because they are tall races or families, and both the tallness and the long fibula will be due to one and the same ontogenetic cause, longcontinued growth. It is no accident, probably, but the result of a common genetic and ontogenetic agency, that South Italians are (1) short of stature, (2) short-limbed, and (3) mature (cease to grow) early, whereas Swedes and Scotch are (1) tall, (2) long-limbed, and (3) mature late. There is a similar difference between the Polish and Flemish breeds of rabbits. We have evidence of the most positive sort that a single genetic agency is responsible in one case for (1) small size, (2) short ears, and (3) early maturity, and in the other for (1) large size, (2) long ears, and (3) late maturity. In one case we have initial energy of growth small (as evidenced by the form of growth-curve) and soon spent; in the other case, growth energy is strong and persistent. This single difference will account for all the closely correlated size-differences, respectively, of the small and of the large races of rabbits.

What is the nature of this genetic agency? Is it a gene, or an assemblage of linked genes, or what is it? I do not think that we can give a full and final answer to these questions at present, but we can at least outline certain possibilities and exclude others.

First, inheritance of large or small size in rabbits is influenced equally by the father and by the mother. No difference can be detected between the results of reciprocal matings between largesized and small-sized races. This indicates that sperm no less than egg is the vehicle of transmission and makes it probable that the chromosomes are concerned in the transmission. If so, the agency may properly be a gene or genes.

\section{THE NUMBER OF SIZE GENES.}

It is clear from the results of crosses between large-sized and smallsized races of rabbits that more than one gene must be involved, since there is no reappearance in $\mathrm{F}_{2}$ of the grand-parental size-classes. The question may be raised how many genes, supposing all to be of like influence on size, will account for the observed $F_{2}$ distribution. There are two ways in which one might attempt a statistical solution of this question. He might consider how frequently the grandparental conditions (extremely large or extremely small) reappear in $\mathrm{F}_{2}$ and make this a basis for estimating the number of independent 
genetic factors involved. Thus, reappearance of the extremely large type in 1 individual in 4 would indicate one genetic factor; its reappearance once in 16 individuals would indicate two factors, and so on; but in the present case the extremely large type has not reappeared at all in $\mathrm{F}_{2}$, so that this method is scarcely applicable. On the multiple-factor theory, it may be that too small a number of $F_{2}$ individuals has been produced to make the reappearance of an extreme type probable; but the form of the variation curve for $F_{2}$ would still be available as an index of the number of factors involved, even if this curve was not sufficiently extended to include the grand-parental classes. With this idea in mind, I have suggested (Castle, 1921) a comparison of the standard deviation of $\mathrm{F}_{2}$ with the standard deviation of $F_{1}$ as a basis for estimating the number of independent factors involved in cases of so-called blending inheritance. Dr. Sewall Wright, who has kindly assisted in this matter, gives the following formula for computing the number $(n)$ of independent factors involved:

$$
n=\frac{D^{2}}{8\left(\sigma_{2}{ }^{2}-\sigma_{1}{ }^{2}\right)}
$$

In this formula $D$ is the difference between the means of the parental (pure) races, $\sigma_{1}$ is the standard deviation of $F_{1}$, and $\sigma_{2}$ is the standard deviation of $\mathrm{F}_{2}$.

In table 31 are shown the results obtained by applying this formula to the six most important measurements studied in the case of each of the three different racial crosses. For the Polish-Himalayan cross, in which the parent races do not differ greatly in size, a difference of from one to three genetic factors is indicated by the different measurements studied, the average being two factors. For the Himalayan-Flemish cross the indicated number of factorial differences ranges from 5 to 10 , average 8.2. In both these crosses the results are fairly consistent throughout the different measurements. But this is not the case in the Polish-Flemish cross. Here the bonemeasurements give low values (between 5 and 6), evidently too low, since they are less than those of the Himalayan-Flemish cross, in which the parent races differ less. But the weight and ear-length values are high, about double the values given by the HimalayanFlemish cross. The average for the series is 10.5 , which is a value of the proper magnitude in relation to the values given by the other two series, since the number of factorial differences between Polish and Flemish, one would suppose, should about equal the sum of the differences (1) between Polish and Himalayan and (2) between Himalayan and Flemish, because Himalayan stands in size between the other two races. It is noteworthy that the results given by weight and by ear-length respectively are in each cross very similar. 
The fact is appreciated that these are at best rough estimates, since (1) it is improbable that all genetic factors affecting size have individually the same amount of influence, and (2) it is improbable that the $F_{1}$ generation is in each case devoid of genetic variability, both of which assumptions are made in the formula employed. Nevertheless, the results may have some value as indicating whether many or few chromosomes are concerned in the inheritance of size in these crosses, if we adopt the chromosome hypothesis. Any additional test which we can apply to that hypothesis will have cumulative value.

The number of chromosomes in the rabbit, according to the summary of Miss Harvey (1920), is estimated by the most recent observers at 10 to 12 , an earlier estimate being 14 to 18 . It would accordingly seem probable, on the chromosome hypothesis, that all the chromosomes are concerned in size inheritance in such a wide cross as that between Polish and Flemish Giant rabbits, while in the other crosses part only of the chromosomes are concerned.

We should by this method not expect to find a number of factors indicated greater than the total number of chromosomes, since even if several or many genes in a single chromosome influenced size, these would not appear in the general result as independent agencies, but as a single agency consisting of a linked system. The result given by this formula must accordingly be interpreted, not as indicating the total number of genes affecting size, but as the probable number of chromosomes (or linkage systems) containing such genes.

\section{SIZE AND SEX.}

The relation of size to sex in rabbits has already been discussed briefly in connection with weight; we may now discuss this question further, and in relation to bone-dimensions and ear-length as well as weight. For this purpose, the groups of cross-bred rabbits afford the best material, because their numbers are largest and they are free from possible effects on size of different degrees of inbreeding. The pertinent facts are brought together in table 32 . It will be observed that males are consistently larger in all bone measurements, but females surpass in weight. Yet none of the differences is very great. It is evident that the male is a bigger-framed animal than the female (as in mammals generally), though the female puts on more flesh. But the size-differences of the sexes are less than in most mammals. In length of leg-bones the male exceeds the female by percentages ranging from 0.5 to 1.5 . In skull-length the difference is very slight, 0.1 or 0.2 per cent. But in males the skull-width, between the outer edges of the zygomatic arches, is greater by 2 or 2.5 per cent. Wright (1918), on the basis of MacDowell's observations, assumed that sex is a specific differential factor affecting the 
length of the hind-leg in rabbits, but it is evident from table 32 that the action of this factor is general, not local, and that it affects the general framework of the rabbit, not its leg-length alone or its hind-leg rather than its front-leg.

In the size of the soft parts of the body-as, for example, earlength and body-weight-females in general surpass males. But it is possible that this difference would not hold for certain small races of rabbits. We have already noted that in our pure Polish rabbits the average weight of the males was actually greater than that of females, although in all the large races and in all our cross-breds, females are heavier than males, the difference amounting to about 5 per cent. In ear-length there is very little if any difference between the sexes. Males have slightly longer ears among the Polish-Himalayan crossbreds, but females among the Flemish cross-breds. The differences are of doubtful statistical significance.

The differences in size due to sex are too small to affect materially the correlation coefficients obtained by comparing bone-measurements, ear-length, and weight, as in tables 12 to 30 . Of this I convinced myself by making separate correlation tables for the two sexes in the case of weight correlated with length of tibia, in which the disturbance due to sex would be at a maximum, since males and females would in these two characters diverge most and in opposite directions, males having a longer tibia, but females being heavier. The correlation between weight and tibia based on both sexes is $0.758 \pm 0.015$ (table 20). For the males alone it is $0.745 \pm 0.023$; for the females alone it is $0.775 \pm 0.021$. The correlation is not increased by tabulating the sexes separately. For the sexes combined the correlation is practically the mean of the values obtained for the sexes separately. Neither sex departs more than the probable error from the combined value.

\section{TESTS FOR LINKAGE WITH COLOR OR OTHER COAT CHARACTERS.}

Hoshino (1915) demonstrated the existence in garden peas of a strong linkage in heredity between a quantitatively varying character, time of flowering, and red color of the flowers. It would be of interest to know whether in animals a similar linkage exists between large or small size and any particular color gene. I can not discover that such is the case in rabbits, probably for the reason that size in rabbits is determined by genes located in many or all chromosomes, whereas each color gene is located in a single chromosome. In each of the two crosses with Flemish, a different albino allelomorph was introduced by the small-sized parent. Albinism was completely recessive in $F_{1}$, but reappeared in $F_{2}$ in approximately one-fourth of the individuals. If any linkage existed between albinism and small 
size, a majority of the $\mathrm{F}_{2}$ albinos should have been of small size, averaging less in weight than their colored brothers and sisters. Such was not the case. In the Polish-Flemish cross, 29 out of 113 $\mathrm{F}_{2}$ individuals reared to maturity were albinos. The average adult weight of the albinos was 2,155 grams, that of the entire $F_{2}$ population was 2,128 grams. The albinos were actually a little larger than the average, although they inherited their albinism from the small-sized grandparent. Hence no linkage is indicated. In the HimalayanFlemish cross a similar result was obtained; 11 out of 62 adult $\mathrm{F}_{2}$ individuals were Himalayan albinos. They averaged in weight 2,535 grams, the average for the entire population (62) being 2,468 grams, or slightly less. The small size of the Himalayan grandparent did not make the Himalayan individuals any smaller (or even quite as small) as their colored brothers and sisters. Hence no linkage is indicated.

Yellow color and dilute pigmentation are two recessive unitcharacters which were transmitted by the Polish male used in the Polish-Flemish crosses, but were not transmitted by the Flemish animals used in those crosses. This fact affords an opportunity to test the occurrence of linkage between small size and either yellow or dilute pigmentation.

Three yellow $F_{2}$ males averaged in adult weight 2,133 grams. The entire group of $28 \mathrm{~F}_{2}$ males, of which the 3 yellows formed a part, ${ }^{1}$ all having descended from the same pair of grandparents, averaged 2,156 grams, substantially the same amount. Hence there is no indication of linkage between yellow and small size.

Fourteen $\mathrm{F}_{2}$ dilute individuals derived from the mating just mentioned or from other reciprocal Polish-Flemish matings averaged in weight 2,086 grams, while the average weight of the entire $F_{2}$ generation in this cross was 2,126 grams, which is only 40 grams heavier. This difference again is too small to give any probable indication of linkage between dilution and small size.

Another recessive coat-character, angora (long woolly hair), appeared unexpectedly in the $\mathrm{F}_{2}$ generation of a cross between a Flemish female (7) and the Polish male (3). A further study of the case showed that the angora character was transmitted by the Flemish parent but not by the Polish. In this case, then, linkage, if found at all, should be found between large size and angora coat; 10 adult angoras occurred among the $42 \mathrm{~F}_{2}$ young reared from this mating. The angoras averaged in weight 2,174 grams; the entire $F_{2}$ group averaged 2,194 grams, or 20 grams heavier. Clearly, therefore, angora was not linked with large size.

\footnotetext{
1 The reader may wonder why the number of yellow grandchildren was so small. In reality a fourth yellow individual was produced, a female, but she died before attaining adult size. Further, the Polish grandparent transmitted yellow in only half his gametes, so that only part of the $F_{1}$ individuals inherited the character from him.
} 
It can therefore be stated with confidence that no linkage is found between large or small size and the four coat-characters, albinism, dilution, yellow, and angora. A reason for this has already been suggested, that each of the coat-characters is determined by a single recessive gene borne probably in a single chromosome, and in the case of each of the four characters in a different chromosome, whereas size depends on many genes borne probably in many different chromosomes or in all the chromosomes.

In table 33 is recorded the color of each rabbit studied, but an examination of these records reveals nothing essentially new as regards color inheritance. It does, however, serve to confirm the discovery made by Punnett (1912) of a peculiar form of the extension factor $(E)$ which he observed in the offspring of a certain Himalayan rabbit. To be sure, Punnett did not call it a peculiar form of the extension factor, but rather a darkener $(D)$ inseparably coupled with the extension factor $(E)$, so that the supposed couplet, darkened extension ( $D E$ of Punnett), behaved as the allelomorph of ordinary extension $(E)$ and of yellow $(e)$. A series of 3 allelomorphs was thus established by Punnett's observations, and it would seem desirable for simplicity so to designate them. I have elsewhere employed the symbol $E^{\prime}$ for Punnett's darkened extension $(D E)$. The order of dominance of the 3 allelomorphs is $E^{\prime}$ (dark extension), $E$ (ordinary extension), $e$ (restriction or yellow).

Our observations on the Flemish crosses reveal the probable source of Punnett's peculiar darkened extension found in his Himalayan doe 7. No Himalayans of pure race, that we have had, possessed the darkened extension, but it is regularly present in Flemish Giant rabbits of the varieties steel gray and black. Doubtless Punnett's Himalayan doe 7 was derived from a Flemish cross made with the idea of intensifying or darkening the pigmented markings of the Himalayan (nose, ears, tail, feet).

All our pure Flemish rabbits have possessed darkened extension. The black doe, B, was apparently homozygous for this factor. She transmitted it to two young, $\sigma^{7} 2473$ and $\$ 2474$, which she had by the Polish male 3, whose formula was Ee. These two young are recorded as black, but as full-grown adults it was noted that each of them at times showed slight indications of ticking on the neck or front legs, and among their offspring were typical steel grays (e. g.,

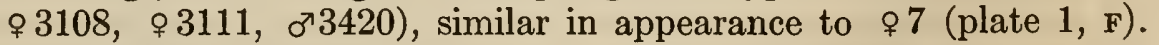
That animal was heterozygous for dark extension, her formula being $E^{\prime} E$. Mated with the Polish buck 3 , she had a litter of 9 young, of which 5 were gray, 2 steel-gray, and 2 black. The 5 gray never produced any steel-grays when mated inter se, which shows that they did not inherit darkened extension, but only ordinary extension, $E$. But the steel-gray and the black young produced 
steel-gray offspring in various matings, and this shows that they did inherit darkened extension, $E^{\prime}$, from their mother. Their sire, as we have stated, did not transmit $E^{\prime}$, but was of the formula $E e$. The steel-gray Flemish buck 2, used in crosses with both Polish and Himalayan does, was also heterozygous for dark extension, his formula being $E^{\prime} E$. By Himalayan does $(E E)$ he had 8 steel-gray and 9 gray offspring (see table $33, \mathrm{VI})$. By Polish does $(E E$ or $E e$ ) he had 10 steel-gray and 6 gray young (table $33, V$ ). Unlike $\$ 7$, he had no black young. He was homozygous for the gray or agouti factor $(A)$ whereas $\$ 7$ was probably heterozygous for this factor. Hence the two black young of $\$ 7$, her formula being $E^{\prime} E A a$, but that of $\sigma^{\prime} 2$ being $E^{\prime} E A A$.

These results confirm the conclusions of Punnett and show that-

(1) Any individual which is homozygous for darkened extension is devoid of agouti ticking, whether or not the agouti factor is present. Examples are found in black Flemish and black Siberian rabbits. (2) Any individual which is heterozygous for dark extension $\left(E^{\prime} E\right.$ or $E^{\prime} e$ ) will ordinarily be steel gray in color ("agouti-black," Punnett) if the agouti factor is present, either heterozygous or homozygous, but such individuals are often black (showing no trace of agouti ticking) in their first coat, although they develop the ticking in later pelages.

However, some individuals of formula $E^{\prime} E A a$ may show little or no ticking in their adult pelages, as, for example, the $F_{1}$ 9474 and her brother $0^{7} 2473$, which produced steel-gray young as well as black ones when mated with each other. If the allelomorph of $E$ present in a heterozygous individual is $e$ rather than $E$, the steel-gray is usually (perhaps always) clearly visible in the adult coat. Punnett speaks of individuals of this sort as invariably "black," but his. classifications were apparently based exclusively on the juvenile coat.

In the $\mathrm{F}_{2}$ generation of the Flemish-Polish cross, but not of the Flemish-Himalayan cross, appeared dilute pigmented individuals having dark extension. These I have called "steel-blue" and "blue." They correspond with the classes steel gray and black of the intensepigmented series. From the fact that no dilutes appeared in $\mathrm{F}_{2}$ from the Flemish-Himalayan cross, it is clear that dilution was introduced in the Polish race, but not in either of the other races. Similar reasoning shows that the color yellow (e) also was not present in either the Flemish or the Himalayan individuals employed in the crosses, but only in the Polish individuals; for yellow $\mathrm{F}_{2}$ individuals appear in the Polish-Flemish cross, but not in the Himalayan-Flemish cross. Finally, angora coat appears in $F_{2}$ of the Polish-Flemish cross, but not in either of the other crosses. Even in the Polish-Flemish cross angora appears only in the $F_{2}$ of a single mating, that between Flemish o 7 and Polish or3. But $\sigma^{7} 3$ was employed also in the Himalayan-Polish crosses, yet no angora 
individuals appeared in those crosses. Therefore $\sigma^{\text {Tr}} 3$ can not have transmitted angora coat. Accordingly, Flemish $\$ 7$ must have done so. She was not employed in the Flemish-Himalayan cross, otherwise we should have expected to see angora individuals in the $\mathrm{F}_{2}$ of that cross also.

\section{SUMMARY.}

1. Studies have been made of the weight, ear-length, and several bone-dimensions of three races of rabbits, and of the first and second generation hybrids between these races.

2. Two of the races (Polish and Himalayan) are of small size, like the wild rabbit of Europe, the ancestral species. The third race (Flemish Giant) is very large, a racially new condition.

3 . Crosses between the pure races produce in general individuals of intermediate size both in $F_{1}$ and $F_{2}$, so that the inheritance is correctly described as blending. But when the parent races do not differ greatly in size (as, for example, the Polish and Himalayan races), the size of $F_{1}$ individuals may be increased by heterosis beyond what it would be through inheritance alone, so that the size of the larger pure race is approximated or even surpassed. Nevertheless, with the disappearance of the heterosis effect in $\mathrm{F}_{2}$ the average size of the cross-breds sinks to a strictly intermediate position.

4. The heterosis effect is seen in the $F_{1}$ generation produced by crossing a large with a small race, no less than in the cross between two small races, but when the difference in size between the races crossed is large, the heterosis effect is not sufficient to obscure the essentially blending or intermediate character of the inheritance in $\mathrm{F}_{1}$. It merely produces a rise in the $\mathrm{F}_{1}$ average size above the strictly intermediate position, which $\mathrm{F}_{2}$ in every cross closely approaches.

5. The variability in size of $\mathrm{F}_{2}$ is regularly greater than that of $\mathrm{F}_{1}$, which in accordance with the multiple-factor hypothesis is regarded as indicating the occurrence of genetic factors affecting size in several different chromosomes or linkage systems.

6. An attempt has been made by statistical methods to estimate how many different chromosomes (or linkage systems) are concerned in the inheritance of the size-differences found in the three race crosses, with the following average results: for the Polish-Himalayan cross, at least two chromosomes; for the Himalayan-Flemish cross, about eight chromosomes; for the Polish-Flemish cross, ten or more chromosomes. As the total number of chromosomes in the rabbit is estimated at 10 to 12 pairs, it seems probable that all chromosomes are concerned in size-inheritance.

7. A study has been made of the correlation between weight, earlength, and the several bone-dimensions studied, with a view to discovering whether the same genetic agencies influence size in different 
parts of the body, or whether factors, independent one of another, govern size in different parts of the body. The conclusion is reached that the genetic agencies affecting size in rabbits are general in their action, influencing in the same general direction all parts of the body. The same would probably be found true for man and other mammals, perhaps for vertebrates in general, but not for plants in which hormone action is less in evidence.

8. No linkage relation has been found to exist between size and any simple (unifactorial) Mendelian character, such as albinism, yellow coat-color, dilution, or angora coat. This result is in harmony with the view that unifactorial characters have their genes located each in a single chromosome, while size is influenced by genes located in many or all chromosomes.

9. In rabbits, size differences correlated with sex are very slight. In skeletal dimensions the adult male averages larger by 1 or 2 per cent, but in weight females surpass males, particularly in the larger breeds of rabbits; yet the differences are so small as not to disturb appreciably the correlation coefficients based on data in which both sexes are included. In ear-length no significant difference between the sexes can be detected.

\section{TABLES.}

TABLE 1.-Average weight in grams of rabbits of the several groups studied, at various ages. Data used in the construction of figure 3.

\begin{tabular}{|c|c|c|c|c|c|c|c|c|c|c|c|c|c|c|}
\hline \multirow{2}{*}{ Group. } & \multirow{2}{*}{ No. } & \multicolumn{13}{|c|}{ Age in days. } \\
\hline & & 30 & 40 & 60 & 90 & 120 & 150 & 180 & 210 & 240 & 270 & 300 & 330 & 360 \\
\hline Polish. & 20 & 308 & 414 & 549 & 779 & 973 & 1133 & 1244 & 1284 & 1297 & 1311 & 1328 & 1344 & 1359 \\
\hline Himalaya & 5 & & 422 & 574 & 824 & 1049 & 1240 & 1423 & 1536 & 1659 & 1705 & 1753 & 1800 & 1806 \\
\hline Flemish. & 2 & 605 & 870 & 1172 & 1800 & 2260 & 2630 & 2820 & 2940 & & & & & 3240 \\
\hline$F_{1}, P \times H$. & 25 & 363 & 459 & 661 & 1002 & 1307 & 1580 & 1752 & 1854 & 1898 & 1927 & 1952 & 1962 & 1971 \\
\hline$F_{1}, P \times F$. & 27 & 377 & 478 & 683 & 1210 & 1641 & 1988 & 2166 & 2283 & 2388 & 2443 & 2466 & 2485 & 2507 \\
\hline $\mathrm{F}_{1}, \mathrm{P} \times \mathrm{H}$ & 16 & 350 & 521 & 769 & 1227 & 1802 & 2154 & 2386 & 2553 & 2680 & 2719 & 2752 & 2789 & 2826 \\
\hline
\end{tabular}

TABLE 2.-Comparative weights in grams of the two sexes in the groups of rabbits studied.

\begin{tabular}{|c|c|c|c|c|c|}
\hline Group. & No. of males. & Av. wt. males. & No. of females. & Av. wt. females. & Difference. \\
\hline Polish. & 10 & 1424 & 10 & 1403 & -21 \\
\hline Himalayan. & 1. & 1880 & 5 & 1870 & -10 \\
\hline$F_{1}, \mathbf{P} \times \mathbf{H} .$. & 15 & 1957 & 10 & 2005 & +48 \\
\hline$F_{3}, P \times H .$. & 23 & 1560 & 27 & 1704 & +144 \\
\hline$F_{1}, P \times F$. & 14 & 2469 & 13 & 2545 & +76 \\
\hline$F_{2}, P \times F$. & 61 & 2080 & 52 & $217 \theta$ & +98 \\
\hline$F_{1}, \underline{B} \times F$ & 8 & 2694 & 8 & 2886 & +192 \\
\hline$F_{2}, H \times F .$. & 30 & 2401 & 32 & 2531 & +130 \\
\hline
\end{tabular}


TABLE 3.-Classification as to weight of the several groups of rabbits studied.

[Class 10 includes weights 1,000 to 1,099 grams; class 11 includes weights 1,100 to 1,199 , etc. There are no data for columns $11,32,33,35$ to 39 , and they are therefore omitted.]

\begin{tabular}{|c|c|c|c|c|c|c|c|c|c|c|c|c|c|c|c|c|c|c|c|c|c|c|}
\hline Group. & 10 & & 13 & & & & & 19 & & 212 & & & $4 \mid 25$ & 26 & $27 \mid 2$ & & $9|30|:$ & 31 & $34 \mid 40$ & 同 & 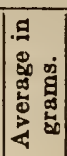 & 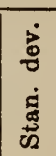 \\
\hline $\begin{array}{l}\text { Polish...... } \\
\text { Himalayan. } \\
\text { Flemish... } \\
\mathrm{F}_{1}, \mathrm{P} \times \mathrm{H} . . \\
\mathrm{F}_{2}, \mathrm{P} \times \mathrm{H} . . \\
\mathrm{F}_{1}, \mathrm{P} \times \mathrm{F} \ldots \\
\mathrm{F}_{2}, \mathrm{P} \times \mathrm{F} \ldots \\
\mathrm{F}_{1}, \mathrm{H} \times \mathrm{F} . . \\
\mathrm{F}_{2} . \mathrm{H} \times \mathrm{F} \ldots\end{array}$ & $\begin{array}{c}1 \\
\cdots \\
\cdots\end{array}$ & 6 & $\begin{array}{c}3 \\
. \\
. \\
\therefore \\
5 \\
\therefore \\
\cdots \\
.\end{array}$ & $\begin{array}{c}6 \\
\cdots \\
\cdots \\
.\end{array}$. & \begin{tabular}{c|c}
3 & \\
$\cdots$ & \\
$\cdots$ &. \\
1 & \\
7 & 1 \\
. & 1 \\
1 &. \\
$\cdots$ &.
\end{tabular} & \begin{tabular}{r|r}
1 & \\
2 &. \\
2 &. \\
10 & \\
2 &. \\
2 & 1 \\
$\cdots$ &.
\end{tabular} & \begin{tabular}{c|c}
$\cdot$ & 2 \\
2 & 4 \\
7 & 7 \\
3 & $\vdots$ \\
\hdashline & 9
\end{tabular} & $\begin{array}{c}6 \\
4 \\
10 \\
10 \\
\ldots\end{array}$ & $\begin{array}{r}1 \\
3 \\
3 \\
\because \\
1 \\
16 \\
- \\
3\end{array}$ & $\left|\begin{array}{r}3 \\
1 \\
1 \\
18 \\
- \\
7\end{array}\right|$ & \begin{tabular}{r|r}
1 & \\
11 & 1 \\
\hdashline &. \\
4 &.
\end{tabular} & \begin{tabular}{c|c}
1 & \\
1 &. \\
5 &. \\
12 & 1 \\
7 & 1 \\
7 & 1
\end{tabular} & \begin{tabular}{c|c}
1 & $\cdots$ \\
5 & $\ddots$ \\
3 & 4 \\
5 \\
5 & 1 \\
\end{tabular} & $\mid \begin{array}{r}-5 \\
3 \\
2 \\
5\end{array}$ & $\begin{array}{c}3 \\
\therefore \\
5 \\
5\end{array}$ & \begin{tabular}{r|r}
2 & $\cdots$ \\
2 & $\cdots$ \\
2 & 3 \\
3 & 3
\end{tabular} & \begin{tabular}{c|c|}
3 & 2 \\
3 &..
\end{tabular} & $\because$ & 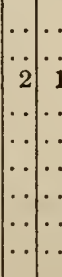 & $\begin{array}{r}20 \\
6 \\
3 \\
25 \\
50 \\
27 \\
112 \\
16 \\
62\end{array}$ & $\begin{array}{l}1404 \\
1866 \\
3646 \\
1973 \\
1652 \\
2512 \\
2126 \\
2827 \\
2472\end{array}$ & $\begin{array}{l}\dddot{218} \\
233 \\
198 \\
257 \\
162 \\
230\end{array}$ \\
\hline
\end{tabular}

TABLE 4.-Statistics of variation in millimeters of ear-length in the several groups of $P_{1}, F_{1}$, and $F_{2}$ rabbits studied.

\begin{tabular}{|c|c|c|c|c|c|}
\hline Race. & No. & Range. & Average. & $\begin{array}{l}\text { Standard } \\
\text { deviation. }\end{array}$ & $\begin{array}{c}\text { Intermediate } \\
\text { between } \\
\text { parent races. }\end{array}$ \\
\hline Polish. & 23 & 81 to 88 & 83.6 & & \\
\hline Himalayan. & 6 & 92 to 97 & 94.8 & & \\
\hline Flemish... & 3 & 143 to 147 & 145.3 & & \\
\hline$F_{1}, P \times H$. & 25 & 90 to 98 & 94.9 & 1.74 & 89.2 \\
\hline $\mathrm{F}_{2}, \mathrm{P} \times \mathrm{H}$. & 55 & 85 to 99 & 92.0 & 3.62 & 89.2 \\
\hline$F_{1}, \mathrm{H} \times \mathrm{F}$. & 17 & 112 to 119 & 115.6 & 2.08 & 120.0 \\
\hline$F_{2}, \mathrm{H} \times \mathrm{F}$. & 70 & 106 to 129 & 115.7 & 5.85 & 120.0 \\
\hline$F_{1}, P \times F$. & 27 & 103 to 116 & 109.3 & 3.76 & 114.4 \\
\hline$F_{2}, P \times F$. & 131 & 93 to 122 & 107.0 & 6.05 & 114.4 \\
\hline
\end{tabular}

TABLE 5.-Comparative average ear-length in millimeters of males and females in the groups of rabbits studied.

\begin{tabular}{|c|c|c|}
\hline Cross. & Males. & Females. \\
\cline { 1 - 2 } & & \\
\cline { 1 - 1 } $\mathrm{F}_{1}, \mathrm{P} \times \mathrm{H} \ldots .$. & 95.4 & 94.2 \\
$\mathrm{~F}_{2}, \mathrm{P} \times \mathrm{H} \ldots$ & 92.5 & 91.6 \\
$\mathrm{~F}_{1}, \mathrm{H} \times \mathrm{F} \ldots$ & 114.5 & 116.6 \\
$\mathrm{~F}_{2}, \mathrm{H} \times \mathrm{F} \ldots$ & 115.7 & 116.5 \\
$\mathrm{~F}_{1}, \mathrm{P} \times \mathrm{F} \ldots$ & 109.1 & 107.7 \\
$\mathrm{~F}_{2}, \mathrm{P} \times \mathrm{F} \ldots$ & 106.9 & 107.1 \\
\hline
\end{tabular}


TABLE 6.-Variation of skull-length in the several groups of rabbits studied.

[All measurements in millimeters.]

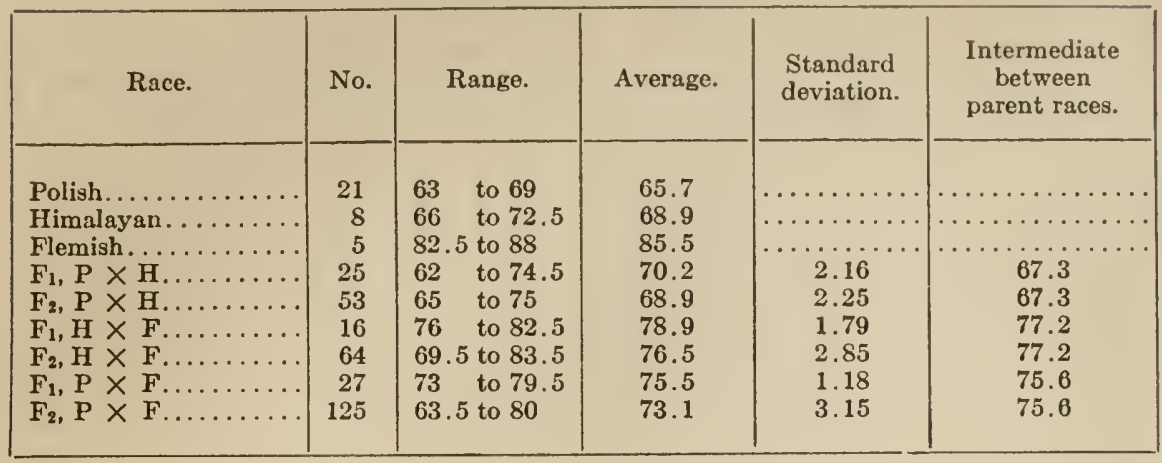

TABLE 7.-Variation in millimeters of anterior skull-width in the several groups of rabbits studied.

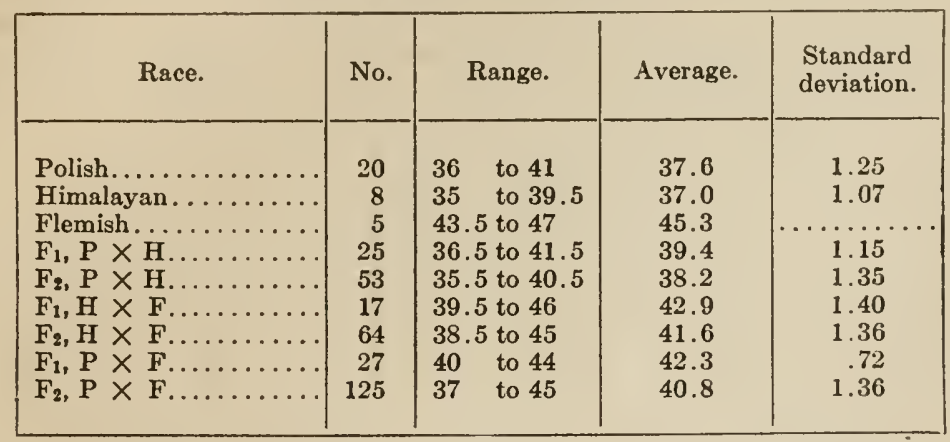

TABLE 8.-Variation in millimeters of posterior skull-width in the several groups of rabbits studied.

\begin{tabular}{|c|c|c|c|c|}
\hline Race. & No. & Range. & Average. & $\begin{array}{l}\text { Standard } \\
\text { deviation }\end{array}$ \\
\hline Polish.. & 20 & 36 to 40.5 & 38.0 & 0.96 \\
\hline Himalayan & 8 & 37 to 40 & 37.9 & 1.09 \\
\hline Flemish & 5 & 44 to 47 & 45.4 & 1.12 \\
\hline$F_{1}, P \times H$. & 25 & 36.5 to 42.5 & 39.5 & 1.33 \\
\hline$F_{2}, P \times H$. & 52 & 35.5 to 40 & 38.1 & 1.17 \\
\hline$F_{1}, H \times F$. & 17 & 40.5 to 44.5 & 43.2 & 0.95 \\
\hline$F_{2}, \mathrm{H} \times \mathrm{F}$. & 64 & 38 to 45 & 42.0 & 1.36 \\
\hline$F_{1}, P \times F$. & 27 & 39.5 to 44 & 42.2 & 1.32 \\
\hline$F_{2}, P \times F$. & 125 & 37 to 44.5 & 40.8 & 1.20 \\
\hline
\end{tabular}


TABLE 9.-Variation in millimeters of length of tibia in the several groups of rabbits studied.

\begin{tabular}{|c|c|c|c|c|c|}
\hline Race. & No. & Range. & Average. & $\begin{array}{l}\text { Standard } \\
\text { deviation. }\end{array}$ & $\begin{array}{c}\text { Intermediate } \\
\text { between } \\
\text { parent races. }\end{array}$ \\
\hline$\ldots \ldots \ldots \ldots$ & 21 & 79 to 89 & 83.9 & 2.26 & \\
\hline Himalayan. . . . . . . . & 8 & 92 to 96 & 93.9 & 1.41 & \\
\hline Flemish ........... & 5 & 105 to 116 & 111.0 & $\ldots \ldots$ & $\ldots \ldots$ \\
\hline $\mathrm{F}_{1}, \mathrm{P} \times \mathrm{H} \ldots \ldots \ldots$ & 25 & 86 to 96 & 92.8 & 2.38 & 88.9 \\
\hline $\mathrm{F}_{2}, \mathrm{P} \times \mathrm{H} \ldots \ldots \ldots$ & 54 & 80 to 96 & 89.8 & 3.39 & 88.9 \\
\hline $\mathrm{F}_{1}, \mathrm{H} \times \mathrm{F} \ldots$ & 17 & 95 to 105 & 99.0 & 2.44 & 102.4 \\
\hline $\mathrm{F}_{2}, \mathrm{H} \times \mathrm{F} \ldots$ & 66 & 90 to 105 & 97.3 & 3.10 & 102.4 \\
\hline$F_{1}, P \times F \ldots$ & 27 & 92 to 100 & 96.2 & 2.27 & 97.4 \\
\hline$F_{2}, P \times F \ldots \ldots$ & 127 & 82 to 104 & 93.4 & 4.75 & 97.4 \\
\hline
\end{tabular}

TABLE 10.-Variation in millimeters of length of femur in the several groups of rabbits studied.

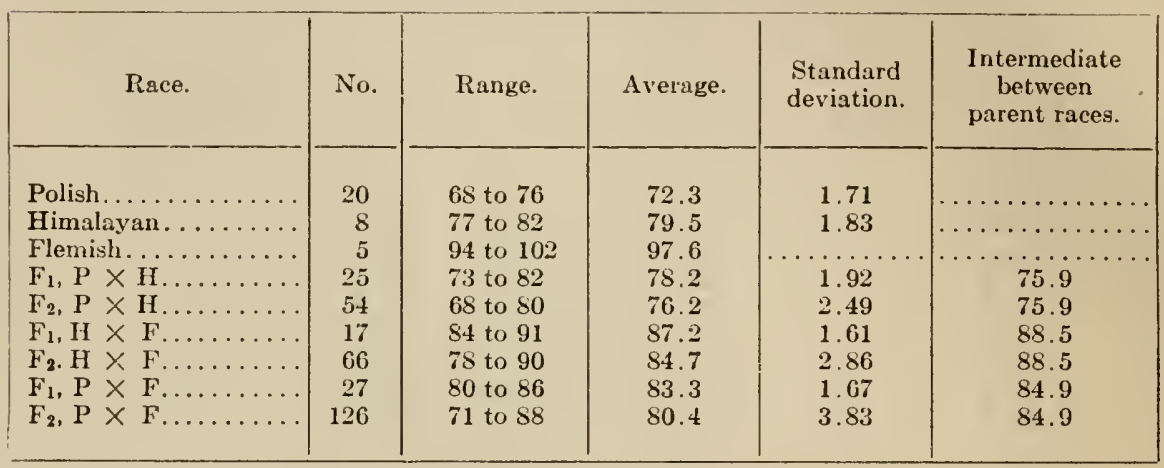

TABLE 11.-Variation in millimeters of length of humerus in the several groups of rabbits studied.

\begin{tabular}{|c|c|c|c|c|c|}
\hline Race. & No. & Range. & Average. & $\begin{array}{l}\text { Standard } \\
\text { deviation. }\end{array}$ & $\begin{array}{c}\text { Intermediate } \\
\text { between } \\
\text { parent races. }\end{array}$ \\
\hline Polish.. & 21 & 54.5 to 60.5 & 57.7 & 1.39 & \\
\hline Himalayan. & 8 & 61.5 to 63.5 & 63.0 & 0.75 & \\
\hline Flemish.. & 4 & 73 to 71.5 & 75.0 & & \\
\hline $\mathrm{F}_{1}, \mathrm{P} \times \mathrm{H}$. & 25 & 59 to 65 & 62.8 & 1.51 & 60.3 \\
\hline $\mathrm{F}_{2}, \mathrm{P} \times \mathrm{H}$. & 51 & 54.5 to 64.5 & 60.9 & 2.37 & 60.3 \\
\hline$F_{1}, H \times F$. & 17 & 66 to 71 & 68.8 & 1.32 & 69.0 \\
\hline $\mathrm{F}_{2}, \mathrm{H} \times \mathrm{F}$. & 66 & 62.5 to 71.5 & 67.3 & 2.26 & 69.0 \\
\hline$F_{1}, P \times F$. & 27 & 63.5 to 68.5 & 66.2 & 1.20 & 66.3 \\
\hline$F, P \times F$. & 126 & 56 to 70.5 & 63.9 & 2.59 & 66.3 \\
\hline
\end{tabular}


TABLE 12.-Correlation of ear-length with weight.

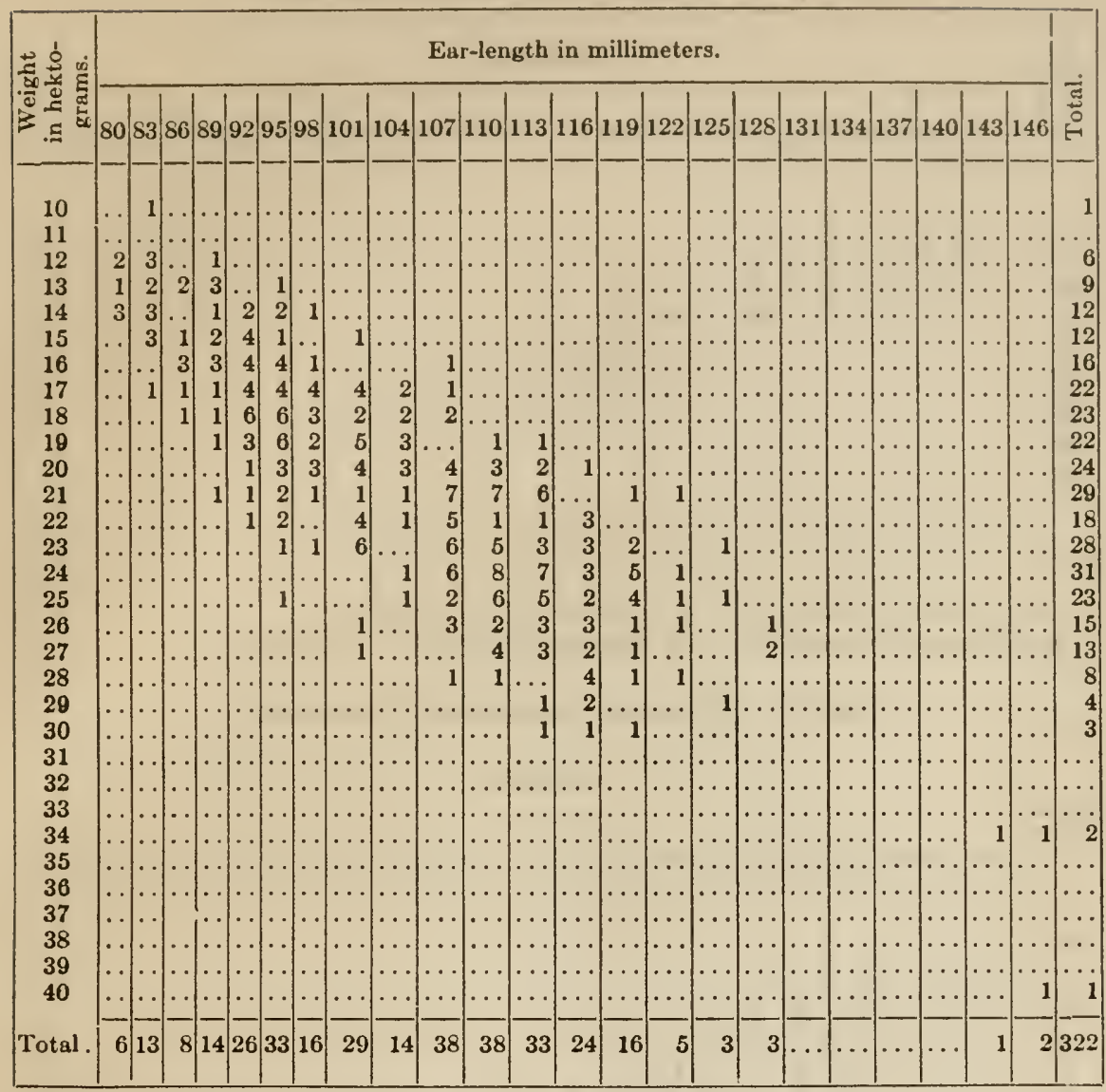

Mean ear-length, $105.35 \pm 0.43$. S. D. ear-length, $3.86 \pm 0.10$.

Mean weight, $214.15 \pm 16.8$. S. D. weight, $448.6 \pm 11.9$. $\quad r, 0.836 \pm 0.011$.

TABLE 13.-Correlation of ear-length with skull-length.

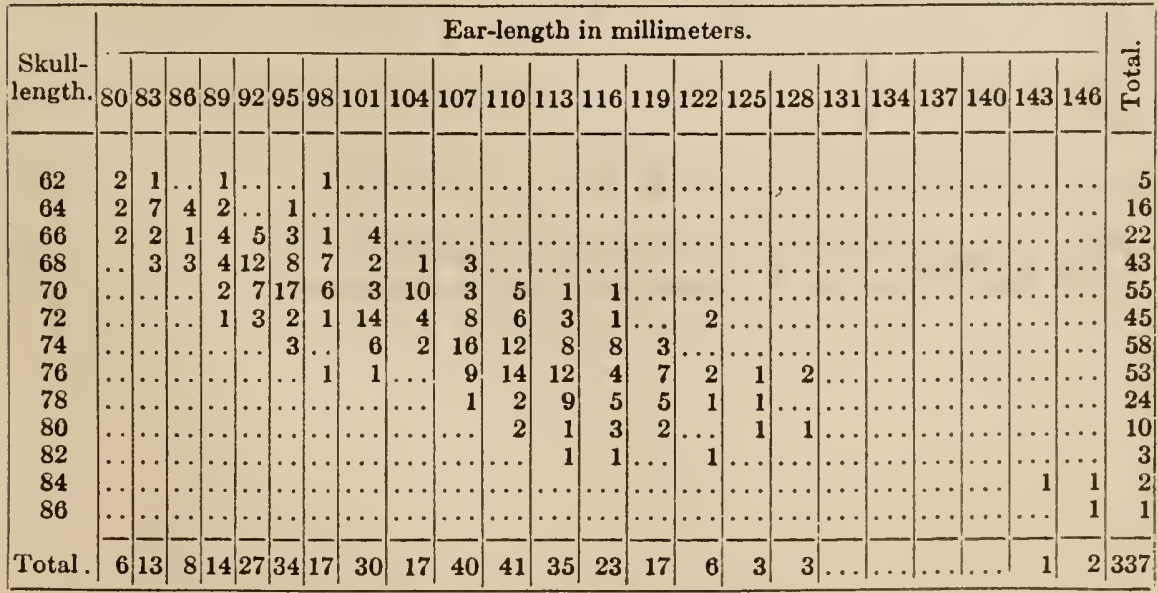

Mean ear-length, $105.45 \pm 0.42$. S. D. ear-length, $11.46 \pm 0.28$.

Mean skull-length, $73.03 \pm 0.16$. S. D. skull-length, $4.42 \pm 0.11 . \quad r, 0.836 \pm 0.011$. 
TABLE 14.-Correlation of ear-length with humerus-length.

\begin{tabular}{|c|c|c|c|c|c|c|c|c|c|c|c|c|c|c|c|c|c|c|c|c|c|c|c|c|}
\hline & \multicolumn{23}{|c|}{ Ear-length. } & \multirow{2}{*}{ 哥 } \\
\hline 国 & & 83 & 86 & 89 & 92 & 95 & 98 & 101 & 104 & 107 & 110 & 113 & 116 & 119 & 122 & 125 & 128 & 131 & 134 & 137 & 140 & 143 & 146 & \\
\hline 54 & 2 & & & 1 & & & & & & & & & & & & & & & & & & & & \\
\hline 56 & 5 & 4 & 2 & 1 & 1 & i & 2 & & & & & & & & & & & & & & & $\ldots$ & . & 17 \\
\hline 58 & . & 5 & 3 & 4 & 5 & 2 & 2 & 1 & & 1 & & . & $\theta$ & .. & & & . & . & . &. & . & $\ldots$ & $\ldots$ & 23 \\
\hline 60 & . & 3 & 3 & 4 & 7 & 3 & 4 & 6 & 6 & 4 & 1 & & .. & . & . & & $\cdots$ & & $\ldots$ & & & $\ldots$ & & 41 \\
\hline 62 & & .. & . & 3 & 14 & 21 & 5 & 13 & 3 & 12 & 6 & & 1 & & & & . & . & $\ldots$ & & & {$[\ldots$} & .. & 78 \\
\hline 64 & & & 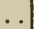 & . . & .. & 7 & 3 & 9 & 7 & 10 & 19 & 7 & 4 & & 1 & & & & . & .. & & $\ldots$ & . & 67 \\
\hline 66 & . & . & . & 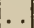 & & .. & .. & $\ldots$ & 2 & 11 & 12 & 14 & 9 & 8 & 1 & & 1 & & & & & & & 58 \\
\hline 68 & & .. & . & . & & . & . & & $\ldots$ & 2 & 3 & 8 & 8 & 6 & 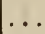 & 3 & 2 & & & & & . & 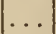 & 32 \\
\hline 70 & & .. & . & . & . & .. & .. & . & $\ldots$ & 1 & $\ldots$ & 7 & 2 & 3 & 3 & & 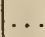 & & & & & & & 16 \\
\hline 72 & & & . & . & . & . & .. & . & ... & $\ldots$ & $\ldots$ & .. & $\ldots$ & & & & & & & & & & 1 & 1 \\
\hline 74 & & & . & . & . & . & . &. & .. & $\ldots$ & $\ldots$ & .. & $\ldots$ & $\ldots$ & $\ldots$ & & & . & . . & .. & .. & & 1 & 1 \\
\hline 76 & & . & . & . & . . & . . & . & $\cdots$ & . & $\cdots$ & $\cdots$ & . . & $\cdots$ & $\cdots$ & . & .. & . & . & . & $\ldots$ & $\ldots$ & 1 & $\ldots$ & 1 \\
\hline Total & & 13 & 8 & 13 & 27 & 34 & 16 & 30 & 18 & 41 & 41 & 36 & 24 & 17 & 5 & 3 & 3 & 3. & & & .. & 1 & & 339 \\
\hline
\end{tabular}

Mean ear-length, $105.46 \pm 0.41$. S. D. ear-length, $11.46 \pm 0.29$.

Mesn humerus, $64.17 \pm 0.13$. S. D. humerus, $3.73 \pm 0.09$. $\quad r, 0.823 \pm 0.011$.

TABLE 15.-Correlation of ear-length with femur-length.

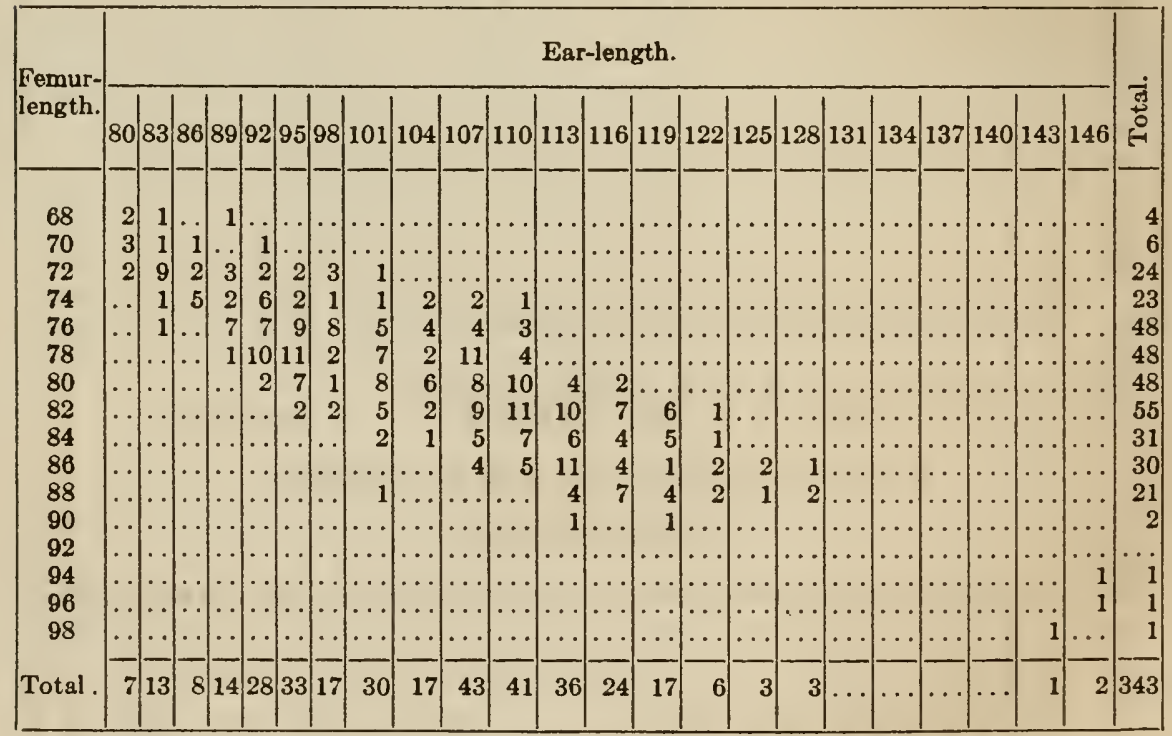

Mean ear-length, $105.45 \pm 0.41$. S. D. ear-length, $11.47 \pm 0.29$.

Mean femur, $80.73 \pm 0.18$. S. D. femur, $5.00 \pm 0.12$. $r, 0.828 \pm 0.011$. 
TABLE 16.-Correlation of ear-length with tibia-length.

\begin{tabular}{|c|c|c|c|c|c|c|c|c|c|c|c|c|c|c|c|c|c|c|c|c|c|c|c|}
\hline \multirow{2}{*}{$\begin{array}{l}\text { Tibia- } \\
\text { length. }\end{array}$} & \multicolumn{22}{|c|}{ Ear-length. } & \multirow{2}{*}{ 岢 } \\
\hline & $8085^{\circ}$ & & & & & & 101 & 104 & 107 & 110 & 113 & 116 & 119 & 122 & 125 & 128 & 131 & 134 & 137 & 140 & 143 & 146 & \\
\hline 80 & & & & & & & & & & & & & & & & & & & & & & & \\
\hline 82 & 4 & 1) & & 1 & & i 3 & & &. & & & 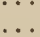 & & & & . & & . . & . & . & & & $\begin{array}{r}5 \\
10\end{array}$ \\
\hline 84 & .. & $\begin{array}{ll}7 & 1\end{array}$ & i) & 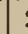 & 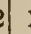 & $\begin{array}{l}1 \\
1 . .\end{array}$ & 1 & & $\ldots$ & 1) & & & & & & $\cdots$ & & ... & $\cdots$ & & & . & 13 \\
\hline 88 & & \begin{tabular}{l|l}
3 & 2
\end{tabular} & & 5 & 3 & $\begin{array}{l}1 \\
\end{array}$ & 3 & 3 & 2 & & & & & & & & & & & & & & 22 \\
\hline 88 &. .1 & 14 & 4] & 1) & !) & $\begin{array}{l}24 \\
2\end{array}$ & 5 & 1 & 3 & 4 & & & . & • & & $\cdots$ & & $\ldots$ & $\ldots$ & & .. & & 29 \\
\hline 90 & .. &. & & 4 & 8 & \begin{tabular}{l|l}
6 & 4
\end{tabular} & 4 & 5 & 8 & 3 & & & . & . & & ... & & & $\cdots$ & & .. & & 42 \\
\hline 92 & & & & 3. & 3 & \begin{tabular}{l|l}
0 & 3
\end{tabular} & 6 & 3 & 10 & 9 & 4 & 1 & & & & $\cdots$ & & & $\cdots$ & & & . & 55 \\
\hline 94 & .. & & & & 4 & $\begin{array}{ll}8 & 2\end{array}$ & 5 & 4 & 6 & 7 & 8 & 4 & 5 & & . & .. & & & ... & . & & . & 54 \\
\hline 96 & .. & & & & & $\begin{array}{ll}5 & 1\end{array}$ & 3. & & 5 & 8 & 6 & 5 & 5 & 3 & & . & & & $\ldots$ & & 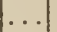 & . & 41 \\
\hline 98 & .. & . & . & . & . &.. & 3 &. & 5 & 9 & 7 & 7 & 2 & 2 & 1 & 1 & & & & & & .. & 37 \\
\hline 100 & .. & & • & & . & $\cdots$ & $\ldots$ & 1 & 2 & $\cdots$ & 6 & 7 & 4 & & 2 & 1 & & & ... & & . & & 23 \\
\hline 102 & ... & . & . & . & . & .. & $\ldots$ & $\cdots$ & 2 & $\ldots$ & 3 & .. & 1 & . & $\ldots$ & 1 & & . & $\ldots$ & & & & 7 \\
\hline 104 & . & . & . & & . & . . & $\cdots$ & & $\ldots$ & .. & 2 & & $\cdots$ & 1 & & & & . . & & & & 1 & 4 \\
\hline 106 & . & & . & . & . & . & $\cdots$ & & & $\cdots$ & $\cdots$ & & & $\cdots$ & & . & & $\cdots$ & & & & $\cdots$ & . \\
\hline 108 & $\cdots$ & 1 & & 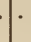 & & & $\cdots$ & & & $\because$ & & & $\cdots$ & & & & & & & & & & \\
\hline 112 & $\ldots$ & & . & . & . & .. & .. & ... & & $\ldots$ & $\cdots$ & $\cdots$ & .. & ... & ... & . & $\ldots$ & $\ldots$ & $\cdots$ & ... & 1 & 1 & 2 \\
\hline Total. & 7.1 & & 81 & 2 & 7 & 417 & 30 & 17 & 43 & 41 & 36 & 24 & 17 & 6 & 3 & 3 & .. & . & & $\cdots$ & 1 & & 344 \\
\hline & & & & & & & & & & & & & & & & & & & & & & & \\
\hline
\end{tabular}

Mean ear-length, $105.42 \pm 0.41$. S. D. ear-length, $11.48 \pm 0.29$.

Mean tibia, $93.64 \pm 0.19$. S. D. tibia, $5.27 \pm 0.13$. $r, 0.741 \pm 0.016$.

TABLE 17.-Correlation of weight with skull-length.

\begin{tabular}{|c|c|c|c|c|c|c|c|c|c|c|c|c|c|c|c|c|c|c|c|c|c|c|c|}
\hline \multirow{2}{*}{$\begin{array}{l}\text { Skull- } \\
\text { length. }\end{array}$} & \multicolumn{22}{|c|}{ Weight in hektograms. } & \multirow{2}{*}{ Total. } \\
\hline & 10 & 11 . & 12 & 13 & 14 . & 15 & 1617 & 718 & 19 & 20 & 21 & 22 & 23 & 24 & 25 & 26 & 27 & 28 & 29 & 30 & 34 & 40 & \\
\hline 62 & & & 2 & & 1 & & 1 & 1 & & & & & & & & & & & & & & & 5 \\
\hline 64 & i & & & 4 & & i) & \begin{tabular}{l|l}
3 &.
\end{tabular} & & .. & $\cdots$ & & . & & & .. & & .. & . & & $\ldots$ & $\cdots$ & $\ldots$ & 13 \\
\hline 66 & . . & & 1 & 2 & $\overline{5}$ & 4 & $\begin{array}{lll}4 & \end{array}$ & & 1 & & & .. & $\ldots$. &. & $\therefore$ & & .. & $\ldots$ & & .. & .. & . & 20 \\
\hline 68 & . & & & 3 & 2 & 5 & \begin{tabular}{l|l}
4 & 9
\end{tabular} & \begin{tabular}{l|l}
9 & 8
\end{tabular} & 5 & 1 & 1) & ... & 1). & & & & $\ldots$ & & & .. & . . & $\ldots$ & 39 \\
\hline 70 & & & & & 1 & 2 & 28 & & 10 & 10 & 6 & 1 & 1] & 2 & & & . & & & .. & $\ldots$ & $\ldots$ & 51 \\
\hline 72 & . . & & . & . & 1 & .. & $\begin{array}{ll}1 & 2\end{array}$ & & 4 & 6 & 6 & 5 & 6 & 5 & 2 & & & & & .. & .. & $\ldots$ & 43 \\
\hline 74 & . . & & . & . & .. & .. & $1 \ldots$ & 1 & 1 & 4 & 12 & 7 & 8 & 7 & 6 & 5 & 2 & 1 & 1 & & & .. & 56 \\
\hline 76 & . & & .. & .. & .. & .. & ... & .. & .. & 3 & 2 & 5 & 7 & 13 & 7 & 4 & 7 & 2 & 1 & 1 & & $\ldots$ & 52 \\
\hline 78 & $\ldots$ & & . & 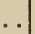 & .. & .. & .. & & T. & & 3 & 1 & 1) & 4 & 6 & 3 & 1 & 4 & & 1 & & $\ldots$ & 23 \\
\hline 80 &. & & $\cdots$ & . & .. & .. & . & $\cdots$ & . & & $\ldots$ & & 2 & 1 & 2 & 1 & 2 & & 2 & 1 & & & 11 \\
\hline 82 & . & & & & . & 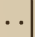 & & 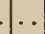 & & & & 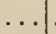 & & $\ldots$ & & $\ldots$ & 1 & 1 & & & & & 2 \\
\hline 84 & . & & & & . & . & . & . & • & . & & .. & $\ldots$ & 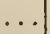 & & L & .. & .. & $\ldots$ & & 2 & & 2 \\
\hline 86 & & & & . & . & . & 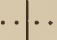 & .. &.. & $\cdots$ & $\ldots$ & $\cdots$ & $\ldots$ & $\cdots$ & $\cdots$ & $\cdots$ & $\ldots$ & $\cdots$ & $\cdots$ & $\cdots$ & $\cdots$ & 1 & 1 \\
\hline Total. & 1 & 1. & 5 & 9 & 12 & 12 & 1623 & 322 & 21 & 24 & 30 & 18 & 26 & 32 & 23 & 13 & 13 & 8 & 4 & 3 & 2 & 1 & 318 \\
\hline
\end{tabular}

Mean weight, $2,141.0 \pm 16.9$. S. D. weight, $447.0 \pm 11.9$.

Mean skull-length, $73.17 \pm 0.16$. S. D. skull-length, $4.38 \pm 0.11 . \quad r, 0.852 \pm 0.010$. 
TABLE 18.-Correlation of weight with humerus.

\begin{tabular}{|c|c|c|c|c|c|c|c|c|c|c|c|c|c|c|c|c|c|c|c|c|c|c|}
\hline \multirow{2}{*}{$\begin{array}{l}\text { Hume- } \\
\text { rus. }\end{array}$} & \multicolumn{21}{|c|}{ Weight. } & \multirow{2}{*}{ Total } \\
\hline & 10 & & 12 & 31 & $141:$ & 516 & 17 & $18 \mid 19$ & 20 & 21 & 22 & 23 & 24 & 25 & 26 & 27 & 28 & 29 & 30 & 34 & 40 & \\
\hline $\begin{array}{l}54 \\
56 \\
58 \\
60 \\
62 \\
64 \\
66 \\
68 \\
70 \\
72 \\
74 \\
76\end{array}$ & $\begin{array}{c}\because \\
\therefore \\
\therefore \\
\because \\
\because \\
\because . \\
\end{array}$ & & $\begin{array}{c}3 \\
2 \\
1 \\
. . \\
. . \\
.\end{array}$ & $\begin{array}{l}1 \\
1 \\
2 \\
2 \\
1 \\
1\end{array}$ & \begin{tabular}{l|l}
4 & \\
4 & \\
2 & \\
3 & \\
&
\end{tabular} & \begin{tabular}{r|r}
2 & \\
3 & 3 \\
2 & 5 \\
2 & 3 \\
2 & 4 \\
& 4 \\
\hdashline \\
\hdashline \\
\end{tabular} & $\begin{array}{c}1 \\
5 \\
7 \\
8 \\
2 \\
. . \\
\therefore \\
\therefore \\
\therefore \\
\therefore \\
. .\end{array}$ & 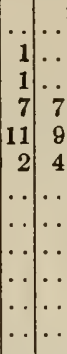 & $\begin{array}{r}4 \\
9 \\
8 \\
4 \\
\cdots \\
\cdots \\
\cdots \\
\cdots \\
\cdots \\
\cdots\end{array}$ & $\begin{array}{r}2 \\
5 \\
14 \\
8 \\
1 \\
\cdots \\
\cdots \\
\cdots \\
\cdots\end{array}$ & $\begin{array}{r}8 \\
7 \\
3 \\
\cdots \\
\cdots\end{array}$ & $\begin{array}{r}\cdots \\
\cdots \\
\cdots \\
6 \\
4 \\
11 \\
3 \\
2 \\
\cdots \\
\cdots \\
\cdots\end{array}$ & $\begin{array}{r}6 \\
7 \\
10 \\
4 \\
5 \\
\cdots \\
\cdots \\
\cdots\end{array}$ & $\begin{array}{r}\cdots \\
6 \\
9 \\
6 \\
2 \\
\cdots \\
\cdots \\
\cdots\end{array}$ & $\begin{array}{r}2 \\
4 \\
6 \\
2 \\
\cdots \\
\cdots \\
\cdots\end{array}$ & $\begin{array}{r}\cdots \\
2 \\
5 \\
5 \\
1 \\
\cdots \\
\cdots \\
\cdots\end{array}$ & $\begin{array}{c}\cdots \\
\cdots \\
\cdots \\
\cdots \\
\cdots \\
1 \\
3 \\
3 \\
1 \\
\cdots \\
\cdots \\
\cdots\end{array}$ & $\begin{array}{r} \\
1 \\
1 \\
2 \\
\cdots \\
\cdots \\
\cdots\end{array}$ & $\begin{array}{r}\cdots \\
\cdots \\
\cdots \\
\cdots \\
2 \\
1 \\
\cdots \\
\cdots \\
\cdots\end{array}$ & $\begin{array}{r}1 \\
\cdots 1 \\
1\end{array}$ & $\begin{array}{l}\cdots \\
\cdots \\
\cdots \\
\cdots \\
\cdots \\
\cdots \\
\cdots\end{array}$ & $\begin{array}{r}3 \\
16 \\
21 \\
39 \\
72 \\
59 \\
58 \\
31 \\
16 \\
1 \\
1 \\
1\end{array}$ \\
\hline Total. & 1 & & 6 & & & $11 \mid 15$ & & $22 \quad 20$ & 25 & 30 & 18 & 27 & 32 & 23 & 14 & 13 & 8 & 4 & 3 & 2 & 1 & 318 \\
\hline
\end{tabular}

Mean weight, $2,146.5 \pm 16.8$. S. D. weight, 445.9 .

Mean humerus, $64.26 \pm 0.14$. S. D. humerus, $3.75 \pm 0.10 . \quad r, 0.820 \pm 0.012$.

TABLE 19.-Correlation of weight with femur.

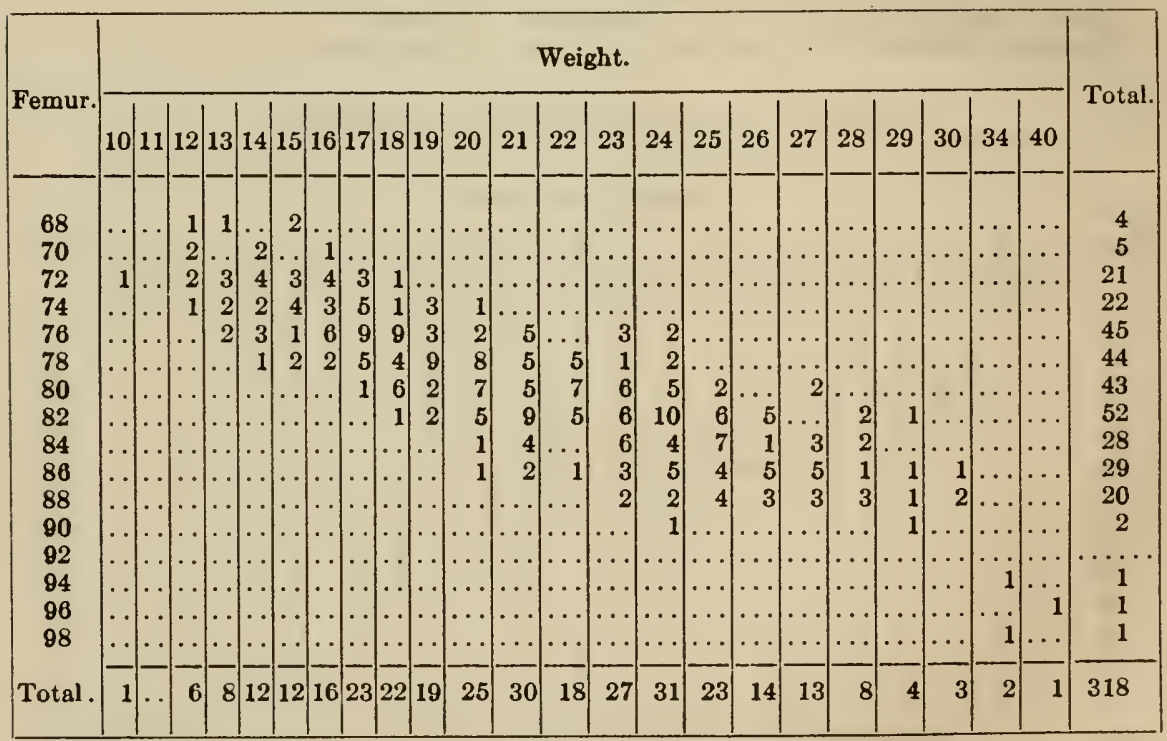

Mean weight, $2,143.0 \pm 16.9$. S. D. weight, $448.0 \pm 11.9$.

Mean femur, $80.80 \pm 0.19$. S. D. femur, $5.03 \pm 0.13$. $r, 0.841 \pm 0.011$. 
TABLF: 20.-Correlation of weight with tibia.

\begin{tabular}{|c|c|c|c|c|c|c|c|c|c|c|c|c|c|c|c|c|c|c|c|c|c|c|c|}
\hline \multirow{2}{*}{ Tibia. } & \multicolumn{22}{|c|}{ Weight. } & \multirow{2}{*}{ Total. } \\
\hline & 101 & 12 & 13 & 14 & & 1 & 1 & & 19 & 20 & 21 & 22 & 23 & 24 & 25 & 26 & 27 & 28 & 29 & 30 & 34 & 40 & \\
\hline 80 & & 2 & 1 & & 1 & & & & & & & & & & & & & & & & & . & 4 \\
\hline 82 & & 1 & & 3 & 2 & 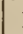 & i & & . . & 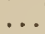 & & & & . & & & & & & $\ldots$ & $\cdots$ & $\ldots$ & 9 \\
\hline 84 & 1 & 2 & 2 & 21 & 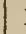 & 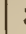 & & & .. & 1 & . & $\cdots$ & & $\cdots$ & & & & & & 1 & $\cdots$ & $\ldots$ & 12 \\
\hline 86 & 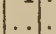 & 1 & 1 & 4 & 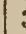 & 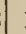 & trat & & 2 & - & .. & $\ldots$ & 1 & 1 & - & & . . & & & 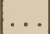 & $\ldots$ & $\ldots$ & 20 \\
\hline 88 & & & 2 & 2 & 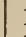 & : & & & 2 & 2 & 2 & 1 & 1 & 1 & & & .. & & & .. & .. & $\ldots$ & 27 \\
\hline 90 & $\because$ & . & 1 & 12 & 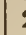 & 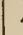 & & & 7 & 5 & 4 & 2 & 1 & 2 & & & .. & & & . . & .. & $\ldots$ & 39 \\
\hline 92 & . & . & & 1 & 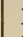 & i: & & & 5 & 3 & 8 & 6 & 5 & 7 & 1 & 2 & 1 & & & .. & $\ldots$ & $\ldots$ & 51 \\
\hline 94 & $\therefore$ & . & . & . & . & 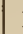 & & & 5 & 7 & 2 & 5 & 5 & 7 & 3 & 3 & 2 & 2 & & . & $\ldots$ & $\ldots$ & 48 \\
\hline 96 & . & . & . & . & . & . & & & 2 & 3 & $\theta$ & 1 & 4 & 4 & 7 & & 2 & 3. & 1 & 1 & & & 38 \\
\hline 98 &. & . & . & . & 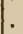 & & & & . & 3 & 4 & 2 & 5 & 4 & 6 & 6 & 4 & 2 & & 1 & & $\ldots$ & 37 \\
\hline 100 & . . & . & . & .. & . & . & & . & .. & 1 & 1 & 1 & 4 & 3 & 5 & 1 & 4 & & 2 & & & 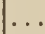 & 22 \\
\hline 102 & . & . & . & . & . & 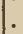 & & & .. & $\ldots$ & $\ldots$ & $\ldots$ & 1 & 2 & 1 & 2 & & & & 1 & & & 7 \\
\hline 104 & & . & . & . & . & t. & & & . & $\ldots$ & $\ldots$ & $\ldots$ & $\ldots$ & 1 & $\ldots$ & ... & .. & 1 & 1 & & 1 & & 4 \\
\hline 112 & . & & . & . & . & & & & . & $\ldots$ & $\ldots$ & $\ldots$ & $\ldots$ & $\ldots$ & $\ldots$ & $\ldots$ & .. & $\ldots$ & $\ldots$ & $\ldots$ & 1 & 1 & 2 \\
\hline Total. & 1. & 6 & & 713 & 1 & 1 & & 2 & 20 & 25 & 30 & 18 & 27 & 32 & 23 & 14 & 13 & 8 & 4 & 3 & 2 & 1 & 320 \\
\hline
\end{tabular}

Mean weight, 2,143.6 \pm 16.8 . S. D. weight, $446.6 \pm 11.9$.

Mean tibia, $93.77 \pm 0.20$. S. D. tibia, $5.29 \pm 0.14$. $r, 0.758 \pm 0.015$.

TABLE 21.-Correlation of humerus-length with skull-length.

\begin{tabular}{|c|c|c|c|c|c|c|c|c|c|c|c|c|c|}
\hline \multirow{2}{*}{$\begin{array}{l}\text { Skull- } \\
\text { length. }\end{array}$} & \multicolumn{12}{|c|}{ Humerus-length. } & \multirow{2}{*}{ Total } \\
\hline & 54 & 56 & 58 & 60 & 62 & 64 & 66 & 68 & 70 & 72 & 74 & 76 & \\
\hline 62 & & 2 & 3 & & & & & & & & & & 5 \\
\hline 64 & 1 & 5 & 5 & 5 & & & & . & $\ldots$ & & & & 16 \\
\hline 66 & 4 & 4 & 7 & 3 & 7 & & & ... & $\ldots$ & & .. & .. & 25 \\
\hline 68 & & 5 & 8 & 13 & 14 & 2 & & & on & & & & 42 \\
\hline 70 & $\cdots$ & $\ldots$ & .. & 14 & 23 & 14 & 3 & & & & .. & $\cdots$ & 54 \\
\hline 72 & ... & $\ldots$ & & 5 & 22 & 11 & 8 & & 1 & & $\cdots$ & $\cdots$ & 47 \\
\hline 74 & & $\cdots$ & 1 & 2 & 9 & 23 & 18 & 3 & 2 & & .. & . . & 58 \\
\hline 76 & ... & $\ldots$ & $\cdots$ & $\ldots$ & 3 & 12 & 21 & 11 & 5 & & & & 52 \\
\hline 78 & & $\ldots$ & & $\ldots$ & $\cdots$ & 2 & 6 & 12 & 4 & & . & & 24 \\
\hline 80 & & ... & ... & 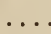 & & $\ldots$ & 4 & 4 & 2 & & & 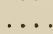 & 10 \\
\hline 82 & & $\cdots$ & ... & $\ldots$ & .. & $\ldots$ & $\ldots$ & 1 & 2 & 1 & & & 4 \\
\hline 84 & ... & . & .. & .. & .. & $\ldots$ & $\ldots$ & $\ldots$ & $\ldots$ & $i$ & & 1 & 2 \\
\hline 86 & $\cdots$ & $\ldots$ & .. & $\cdots$ & $\cdots$ & $\cdots$ & $\ldots$ & ... & $\ldots$ & .... & 1 & $\ldots$ & 1 \\
\hline Total. & 5 & 16 & 24 & 42 & 78 & 64 & 60 & 31 & 16 & 2 & 1 & 1 & 340 \\
\hline
\end{tabular}

Mean humerus, $64.16 \pm 0.13$. S. D. humerus, $3.77 \pm 0.09$.

Mean skull, $72.96 \pm 0.16$. S. D. skull, $4.46 \pm 0.11$. $r, 0.834 \pm 0.011$. 
TABLE 22.-Correlation of femur-length with skull-length.

\begin{tabular}{|c|c|c|c|c|c|c|c|c|c|c|c|c|c|c|c|c|c|c|c|c|}
\hline \multirow{2}{*}{$\begin{array}{l}\text { Skull- } \\
\text { length. }\end{array}$} & \multicolumn{19}{|c|}{ Femur-length. } & \multirow{2}{*}{ Total. } \\
\hline & 68 & 70 & 72 & 74 & 76 & 78 & 80 & 82 & 84 & 86 & 88 & 9 & & & 94 & 96 & 98 & 100 & 102 & \\
\hline 62 & 1 & 1 & 3 & & & & & . & & & & & & & & & & & & 5 \\
\hline 64 & 1 & 1 & 9 & 4 & i) & . &. & .. & & 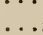 & & & & & . & & & & $\ldots$ & 16 \\
\hline 68 & 2 & 4 & 6 & 4 & 8 & 1 & & . & & & .. & & & & & & & & $\ldots$ & 25 \\
\hline 68 & & $\ldots$ & 7 & 11 & 12 & 9 & 4 & & & & & & & & & & & & $\ldots$ & 43 \\
\hline 70 & & . & & 2 & 15 & 16 & 15 & 6 & & . & & & & & & .. & & $\cdots$ & $\ldots$ & 54 \\
\hline 72 & & . & ... & 1 & 10 & 12 & 9 & 10 & 3. & 1 & & & & & & & . & & $\ldots$ & 47 \\
\hline 74 & & & & 1 & 2 & 6 & 16 & 18 & 9 & 4 & & & & & & & .. &. & $\ldots$ & 58 \\
\hline 76 & & & & $\cdots$ & $\ldots$ & 2 & 4 & 20 & 10 & 14 & & & & & & & & & 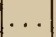 & 53 \\
\hline 78 & & & & & & $\ldots$ & 1 & 1. & 6 & 9 & & & & & & . &. & & $\cdots$ & 24 \\
\hline 80 & & 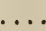 & & . & . & ... & $\cdots$ & $\ldots$ & 2 & 1 & & & & & . & & .. & & ... & 10 \\
\hline 82 & 0 & & & & $\cdots$ & .... & ... & ... & ... & $\ldots$ & & & & & 1 & & $\because$ & & . & 4 \\
\hline 84 & & & & . . & & $\cdots$ & $\cdots$ & .. & $\ldots$ & & & & & & 1 . & & 1 & & & 2 \\
\hline 86 & & & & .. & . & $\cdots$ & $\cdots$ & $\cdots$ & $\cdots$ & $\cdots$ & & & & & .. & 1. & & & & 1 \\
\hline 88 & & 1 & . & $\cdots$ & $\cdots$ & $\cdots$ & $\cdots$ & $\cdots$ & $\cdots$ & $\cdots$ & - & & & & $\cdots$ & .1 & .. & & 1 & 1 \\
\hline Total. & 4 & 6 & 25 & 23 & 48 & 46 & 49 & 55 & 30 & 29 & 2 & & & & 2 & 1 & 1 & . & 1 & 343 \\
\hline
\end{tabular}

Mean femur, $80.80 \pm 0.19$. S. D. femur, $5.20 \pm 0.13$.

Mean skull, $73.06 \pm 0.16$. S. D. skull, $4.53 \pm 0.11 . \quad r, 0.871 \pm 0.008$.

TABLE 23.-Correlation of tibia-length with skull-length.

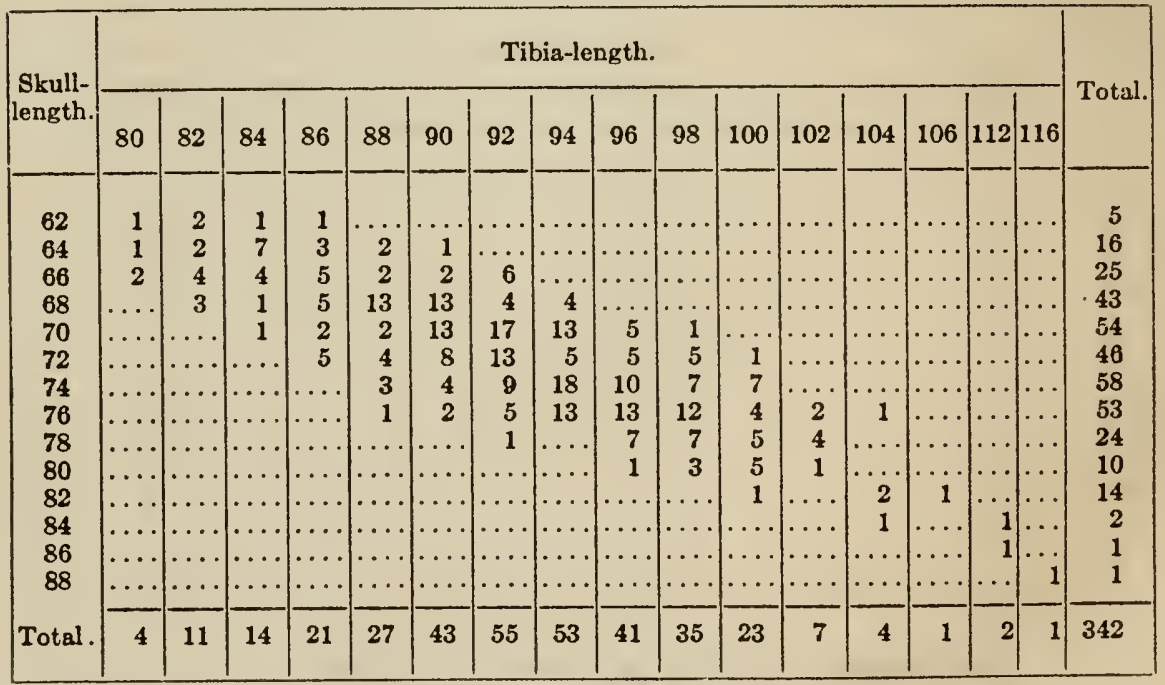

Mean tibia, $93.74 \pm 0.20$. S. D. tibia, $5.45 \pm 0.14$.

Mean skull, $73.06 \pm 0.16$. S. D. skull, $4.54 \pm 0.11$. $\quad r, 0.806 \pm 0.015$. 
TABLE 24.-Correlation of femur with humerus, all groups included.

\begin{tabular}{|c|c|c|c|c|c|c|c|c|c|c|c|c|c|c|c|c|c|}
\hline \multirow{2}{*}{$\begin{array}{l}\text { Hume- } \\
\text { rus. }\end{array}$} & \multicolumn{16}{|c|}{ Femur. } & \multirow{2}{*}{ Total. } \\
\hline & 68 & 70 & 72 & 74 & 76 & 78 & 80 & 82 & 84 & 86 & 88 & 90 & 92 & 94 & 86 & 88 & \\
\hline 54 & 3 & 1 & & & & & ... & $\cdots$ & ... & ... & $\ldots$ & $\ldots$ & & $\ldots$ & . & $\ldots$ & 4 \\
\hline 56 & 1 & 5 & 10 & 2 & . . & & .. & ... & 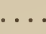 & $\ldots$ & $\ldots$ & $\ldots$ & . & $\ldots$ & . & . . & 18 \\
\hline 58 & ... & 1 & 13 & 10 & & & & & & .. & 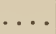 & $\ldots$ & . & $\ldots$ & . & $\ldots$ & 24 \\
\hline 60 & & ... & 2 & 11 & 18 & 9 & 1 & & & & . & $\ldots$ & & $\ldots$ & 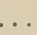 & $\ldots$ & 41 \\
\hline 62 & & $\ldots$ & $\ldots$ & $\ldots$ & 28 & 29 & 18 & 4 & & & & & & & 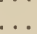 & $\cdots$ & 79 \\
\hline 64 & & & ... & $\ldots$ & 2 & 8 & 26 & 25 & 1 & 2 & & & & . & & .. & 64 \\
\hline 66 & & .. & $\ldots$ & $\ldots$ & $\cdots$ & $\ldots$ & 4 & 26 & 23 & 7 & 1 & & & & & . & 61 \\
\hline 68 & $\cdots$ & . & $\ldots$ & $\ldots$ & $\ldots$ & $\ldots$ & $\ldots$ & $\ldots$ & 7 & 14 & 11 & & & & & .. & 32 \\
\hline 70 & $\cdots$ & & $\ldots$ & $\ldots$ & $\ldots$ & $\ldots$ & $\ldots$ & $\ldots$ & $\ldots$ & 6 & 8 & 2 & & & . & . & 16 \\
\hline 72 & & . & $\ldots$ & $\ldots$ & $\ldots$ & $\ldots$ & $\ldots$ & $\ldots$ & $\ldots$ & $\ldots$ & $\ldots$ & $\cdots$ & & 2 & & . & 2 \\
\hline 74 & .. & & $\ldots$ & $\ldots$ & $\ldots$ & $\ldots$ & $\ldots$ & $\ldots$ & $\ldots$ & $\ldots$ & $\ldots$ & $\ldots$ & $\cdot$ & $\ldots$ & 1 & & 1 \\
\hline 76 & .... & .. & $\ldots$ & $\ldots$ & . & $\ldots$ & $\ldots$ & $\cdots$ & $\ldots$ & $\ldots$ & $\ldots$ & $\ldots$ & .. & $\ldots$ & $\cdots$ & 1 & 1 \\
\hline Total. & 4 & 7 & 25 & 23 & 48 & 46 & 49 & 55 & 31 & 29 & 20 & 2 & & 2 & 1 & 1 & 343 \\
\hline
\end{tabular}

Mean femur, $80.69 \pm 0.18$. S. D. femur, $5.08 \pm 0.13$.

Mean humerus, $64.17 \pm 0.13$. S. D. humerus, $3.78 \pm 0.09$. $\quad r, 0.906 \pm 0.006$.

TABLE 25.-Correlation of femur with humerus, pure races only.

\begin{tabular}{|c|c|c|c|c|c|c|c|c|c|c|c|c|c|c|c|c|c|}
\hline \multirow{2}{*}{$\begin{array}{l}\text { Hume- } \\
\text { rus. }\end{array}$} & \multicolumn{16}{|c|}{ Femur. } & \multirow{2}{*}{ Total. } \\
\hline & 68 & 70 & 72 & 74 & 76 & 78 & 80 & 82 & 84 & 86 & 88 & 90 & 82 & 94 & 96 & 88 & \\
\hline 54 & 1 & 1 & & & & & & & & & & & & & & & 2 \\
\hline 56 & 1 & 4 & 6 & & & & & & & & & & & & .. & $\cdots$ & 11 \\
\hline 58 & $\ldots$ & 1 & 4 & 1 & & & & & $\ldots$ & $\ldots$ & . & .... & & ... & . & $\ldots$ & 6 \\
\hline 60 & $\ldots$ & $\ldots$ & 1 & $\ldots$ & 2 & & & & & & 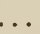 & & & ... & . & $\ldots$ & 3 \\
\hline 62 & $\ldots$ & $\ldots$ & $\ldots$ & $\ldots$ & 2 & 1 & 3 & 1 & & & &. & & $\ldots$ & & $\ldots$ & 7 \\
\hline 64 & $\ldots$ & $\cdots$ & $\cdots$ & ... & $\cdots$ & $\cdots$ & $\cdots$ & $\cdots$ & . & .... & $\cdots$ & & & $\ldots$ & $\cdots$ & . & .... \\
\hline 66 & & $\ldots$ & 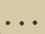 & . & $\ldots$ & $\ldots$ & $\ldots$ & 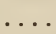 & & $\ldots$ & & $\ldots$ & & $\ldots$ & & .. & $\ldots$ \\
\hline 68 & $\ldots$ & $\cdots$ & .. & $\cdots$ & $\cdots$ & $\cdots$ & $\cdots$ & $\cdots$ & & & & & & $\cdots$ & .. & & $\cdots$ \\
\hline $\begin{array}{l}70 \\
72\end{array}$ & & 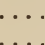 & $\cdots$ & & $\cdots$ & $\cdots$ & ... & $\cdots$ & & & $\cdots$ & & & $\cdots_{2}$ & . & $\cdots$ & $\ddot{2}$ \\
\hline 74 & … & $\ldots$ & $\cdots$ & & ... & .... & $\ldots$ & . & $\cdots$ & $\cdots$ & & $\cdots$ & & $\ldots$ & i & & 1 \\
\hline 76 & $\ldots$ & $\cdots$ & $\ldots$ & $\ldots$ & . & $\ldots$ & .... & .... & ... & $\ldots$ & . & ... & ... & $\cdots$ & . & i & 1 \\
\hline Total. & 2 & 6 & 11 & 1 & 4 & 1 & 3 & 1 & $\ldots$ & . & 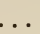 & 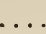 & & 2 & 1 & 1 & 33 \\
\hline
\end{tabular}

Mean femur, 76.95. S. D. femur, 8.06.

Mean humerus, 60.95. S. D. humerus, 5.60. $\quad r, 0.980 \pm 0.004$. 
TABLE 26.-Correlation of femur with humerus, $F_{1}$ only.

\begin{tabular}{|r|r|r|r|r|r|r|r|r|r|r|r|}
\hline $\begin{array}{c}\text { Hume- } \\
\text { rus. }\end{array}$ & \multicolumn{7}{|c|}{ Femur. } & Total. \\
\cline { 2 - 7 } & $\mathbf{7 4}$ & $\mathbf{7 6}$ & 78 & 80 & 82 & 84 & 86 & 88 & 80 & \\
\hline 58 & 1 & $\ldots$ & $\ldots$ & $\ldots$ & $\ldots$ & $\ldots$ & $\ldots$ & $\ldots$ & $\ldots$ & $\ldots$ & 1 \\
60 & $\ldots$ & 2 & 1 & 1 & $\ldots$ & $\ldots$ & $\ldots$ & $\ldots$ & $\ldots$ & $\ldots$ & 4 \\
64 & $\ldots$ & $\ldots$ & 6 & 8 & 3 & $\ldots$ & $\ldots$ & $\ldots$ & $\ldots$ & $\ldots$ & 17 \\
66 & $\ldots$ & $\ldots$ & $\ldots$ & 2 & 5 & 6 & 1 & $\ldots$ & $\ldots$ & $\ldots$ & 14 \\
68 & $\ldots$ & $\ldots$ & $\ldots$ & $\ldots$ & 1 & 6 & 9 & 3 & $\ldots$ & $\ldots$ & 19 \\
70 & $\ldots$ & $\ldots$ & $\ldots$ & $\ldots$ & $\ldots$ & $\ldots$ & 1 & 6 & 4 & $\ldots$ & 11 \\
& 1 & 2 & 7 & 11 & 9 & 12 & 11 & 9 & 6 & 1 & 69 \\
\hline
\end{tabular}

Mean femur, 82.54. S. D. femur, 4.08.

Mean humerus, 65.58. S. D. humerus, 2.68. $\quad r, 0.888 \pm 0.017$.

TABLE 27.-Correlation of femur with humerus, $F_{2}$ only.

\begin{tabular}{|r|r|r|r|r|r|r|r|r|r|r|r|r|r|}
\hline $\begin{array}{r}\text { Hume- } \\
\text { rus. }\end{array}$ & \multicolumn{10}{|c|}{ Femur. } \\
\hline & $\mathbf{6 0}$ & $\mathbf{7 0}$ & $\mathbf{7 2}$ & $\mathbf{7 4}$ & 76 & $\mathbf{7 8}$ & $\mathbf{8 0}$ & 82 & 84 & 86 & 88 & 90 & Total. \\
\hline 54 & 2 & $\ldots$ & $\ldots$ & $\ldots$ & $\ldots$ & $\ldots$ & $\ldots$ & $\ldots$ & $\ldots$ & $\ldots$ & $\ldots$ & $\ldots$ & 2 \\
56 & $\ldots$ & 1 & 4 & 2 & $\ldots$ & $\ldots$ & $\ldots$ & $\ldots$ & $\ldots$ & $\ldots$ & $\ldots$ & $\ldots$ & 7 \\
58 & $\ldots$ & $\ldots$ & 8 & 9 & $\ldots$ & $\ldots$ & $\ldots$ & $\ldots$ & $\ldots$ & $\ldots$ & $\ldots$ & $\ldots$ & 17 \\
60 & $\ldots$ & $\ldots$ & 1 & 9 & 15 & 8 & 1 & $\ldots$ & $\ldots$ & $\ldots$ & $\ldots$ & $\ldots$ & 34 \\
62 & $\ldots$ & $\ldots$ & $\ldots$ & $\ldots$ & 20 & 20 & 12 & 3 & $\ldots$ & $\ldots$ & $\ldots$ & $\ldots$ & 55 \\
64 & $\ldots$ & $\ldots$ & $\ldots$ & $\ldots$ & 2 & 6 & 21 & 19 & $\ldots$ & 2 & $\ldots$ & $\ldots$ & 50 \\
66 & $\ldots$ & $\ldots$ & $\ldots$ & $\ldots$ & $\ldots$ & $\ldots$ & 3 & 20 & 14 & 4 & 1 & $\ldots$ & 42 \\
68 & $\ldots$ & $\ldots$ & $\ldots$ & $\ldots$ & $\ldots$ & $\ldots$ & $\ldots$ & $\ldots$ & 6 & 8 & 7 & $\ldots$ & 21 \\
70 & $\ldots$ & $\ldots$ & $\ldots$ & $\ldots$ & $\ldots$ & $\ldots$ & $\ldots$ & $\ldots$ & $\ldots$ & 6 & 6 & 1 & 13 \\
\hline Total & 2 & 1 & 13 & 20 & 37 & 34 & 37 & 42 & 20 & 20 & 14 & 1 & 241 \\
\hline
\end{tabular}

Mean femur, 80.67. S. D. femur, 4.48.

Mean humerus, 65.21. S. D. humerus, 3.45. r, $0.878 \pm 0.010$.

TABLE 28.-Correlation of tibia with humerus.

\begin{tabular}{|c|c|c|c|c|c|c|c|c|c|c|c|c|c|c|c|c|}
\hline \multirow{2}{*}{$\begin{array}{l}\text { Hume- } \\
\text { rus. }\end{array}$} & \multicolumn{15}{|c|}{ Tibia. } & \multirow{2}{*}{ Total } \\
\hline & 80 & 82 & 84 & 86 & 88 & 90 & 92 & 94 & 96 & 98 & 100 & 102 & 104 & 106 & 112 & \\
\hline $\begin{array}{l}54 . \\
56 .\end{array}$ & $\begin{array}{l}2 \\
3\end{array}$ & $\begin{array}{l}3 \\
7\end{array}$ & 4 & 2 & 1 & & & $\cdots$ & . & & & & & & & $\begin{array}{r}5 \\
17\end{array}$ \\
\hline & $\ldots$ & i & 7 & 12 & 4 & & & $\ldots$ & $\cdots$ & . & $\ldots$ & $\ldots$ & . & $\ldots$ & $\ldots$ & 24 \\
\hline 60. & $\ldots$ & $\ldots$ & 3 & 5 & 14 & 17 & 3 & & & & & & & & & 42 \\
\hline 62. & & $\cdots$ & $\ldots$ & 3 & 7 & 19 & 29 & 15 & 4 & 2 & & & . & . & 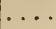 & 79 \\
\hline 64. & $\ldots$ & $\ldots$ & $\ldots$ & $\ldots$ & 2 & 5 & 19 & 20 & 13 & 6 & & & & 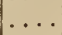 & 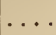 & 65 \\
\hline 66. & $\cdots$ & & .. & 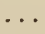 & $\cdots$ & $\ldots$ & 4 & 15 & 21 & 12 & 8 & & & & $\cdots$ & 60 \\
\hline 68. & . & . & .. & $\ldots$ & . . & $\ldots$ & $\ldots$ & 3 & 3 & 12 & 10 & 4 & & & & 32 \\
\hline 70. & $\cdots$ & $\ldots$ & . & $\cdots$ & . & $\ldots$ & $\cdots$ & $\ldots$ & 1 & 4 & 5 & 3 & 3 & & & 16 \\
\hline 72. & . &. & . & $\ldots$ & . & . & . & $\ldots$ & $\ldots$ & 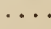 & $\cdots$ & $\ldots$ & 1 & 1 & & 2 \\
\hline & & & & & & & & & & & & & & & 1 & 1 \\
\hline & 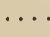 & . & $\ldots$ & $\ldots$ & ... & $\ldots$ & $\ldots$ & $\ldots$ & $\ldots$ & $\ldots$ & $\ldots$ & $\ldots$ & $\ldots$ & $\cdots$ & 1 & 1 \\
\hline Total & 5 & 11 & 14 & 22 & 28 & 41 & 55 & 53 & 42 & 36 & 23 & 7 & 4 & 1 & 2 & 344 \\
\hline
\end{tabular}

Mean tibia, $93.64 \pm 0.19$. S. D. tibia, $5.35 \pm 0.13$.

Mean humerus, $64.15 \pm 0.13$. S. D. humerus, $3.78 \pm 0.09$. $r, 0.904 \pm 0.006$. 
TaBle 29.-Correlation of tibia with femur.

\begin{tabular}{|c|c|c|c|c|c|c|c|c|c|c|c|c|c|c|c|c|c|}
\hline \multirow{2}{*}{ 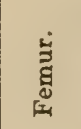 } & \multicolumn{16}{|c|}{ Tibia. } & \multirow{2}{*}{ 息 } \\
\hline & 80 & 82 & 84 & 86 & 88 & 90 & 92 & 94 & 96 & 98 & 100 & 102 & 104 & 106 & 112 & 116 & \\
\hline $68 \ldots$ & 2 & 1 & & & & & & & & & & & & & & & 3 \\
\hline $70 \ldots$ & 3 & 3 & 2 & & & & & & & & & & & & & & 8 \\
\hline $72 \ldots$ & & 7 & 11 & 7 & & & & 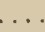 & & $\cdots$ & & $\ldots$ & & .. & $\ldots$ & & 25 \\
\hline $74 \ldots$ & . & $\ldots$ & 1 & 10 & 10 & 2 & & & & & & & & & & & 23 \\
\hline 76. & & $\ldots$ & $\ldots$ & 5 & 12 & 18 & 14 & & & & & & & . & $\ldots$ & & 49 \\
\hline 78. & $\cdots$ & . & . & .... & 5 & 18 & 17 & 6 & 2 & & & & & & & & 48 \\
\hline $80 \ldots$ & & & . & & 1 & 5 & 18 & 17 & 7 & 1 & & .. & & & & & 49 \\
\hline 82. & $\cdots$ & . & $\ldots$ & $\cdots$ & $\ldots$ & $\cdots$ & 6 & 25 & 18 & 6 & & & & & & . & 55 \\
\hline 84. & . & & $\cdots$ & & $\ldots$ & $\cdots$ & $\cdots$ & 5 & 11 & 9 & 6 & & & & & & 31 \\
\hline 86. & . . & $\ldots$ & $\ldots$ & $\ldots$ & $\ldots$ & $\ldots$ & $\ldots$ & $\ldots$ & 2 & 17 & 7 & 3 & & & $\ldots$ & ... & 29 \\
\hline 88. & & $\ldots$ & $\ldots$ & $\ldots$ & $\ldots$ & $\ldots$ & 1 & $\ldots$ & 1 & 4 & 10 & 3 & 2 & & & .. & 21 \\
\hline 90. & . & $\ldots$ & 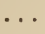 & $\ldots$ & $\ldots$ & . . & $\ldots$ & ... & $\ldots$ & $\ldots$ & $\ldots$ & 1 & 1 & & & $\ldots$ & 2 \\
\hline $92 \ldots$ & * & . & ... & $\cdots$ & $\ldots$ & & $\ldots$ & $\ldots$ & 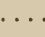 & . & $\cdots$ & $\ldots$ & & & & $\cdots$ & $\ldots$ \\
\hline $94 \ldots$ & . & ... & $\cdots$ & $\ldots$ & ... & .. & ... & $\cdots$ & $\ldots$ & $\ldots$ & & $\ldots$ & 1 & 1 & 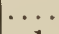 & $\ldots$ & 2 \\
\hline $\begin{array}{l}96 \ldots \\
98 .\end{array}$ & & . & $\ldots$ & $\cdots$ & & & . & & & $\cdots$ & & $\cdots$ & $\cdots$ & $\cdots$ & 1 & $\cdots$ & 1 \\
\hline $\begin{array}{r}98 \ldots \\
102 . .\end{array}$ & & $\ldots$ & $\cdots$ & $\ldots$ & $\ldots$ & . & . & . & $\ldots$ & $\cdots$ & $\cdots$ & $\cdots$ & $\cdots$ & $\cdots$ & 1 & 1 & 1 \\
\hline & & & & & & & & & & & & & & & & & \\
\hline Total. & 5 & 11 & 14 & 22 & 28 & 43 & 56 & 53 & 41 & 37 & 23 & 7 & 4 & 1 & 2 & 1 & 348 \\
\hline
\end{tabular}

Mean tibia, $93.69 \pm 0.19$. S. D. tibia, $5.48 \pm 0.14$.

Mean femur, $80.76 \pm 0.18$. S. D. femur, $5.19 \pm 0.12$. $\quad r, 0.927 \pm 0.005$.

TABLE 30.-Correlation coefficients derived from tables 12 to 29.

\begin{tabular}{|c|c|c|c|c|c|}
\hline Table. & Characters correlated. & Coefficient. & Table. & Characters correlated. & Coefficient. \\
\hline 12 & Ear-length, weight. & $0.836 \pm 0.011$ & 22 & Femur, skull-length. & $0.871 \pm 0.008$ \\
\hline 13 & Ear-length, skull & & 23 & Tibia, skull-length & $0.806 \pm 0.015$ \\
\hline & length........ & $0.836 \pm 0.011$ & 24 & Femur, humerus. & $0.906 \pm 0.006$ \\
\hline 14 & Ear-length, humerus & $0.823 \pm 0.011$ & 25 & Femur, humerus (pure & \\
\hline 15 & Ear-length, femur... & $0.828 \pm 0.011$ & & races only).. & $0.980 \pm 0.004$ \\
\hline 16 & Ear-length, tibia. & $0.741 \pm 0.016$ & 26 & Femur, humerus $\left(F_{1}\right.$ & \\
\hline 17 & Weight, skull-length. & $0.852 \pm 0.010$ & & only).. & $0.888 \pm 0.017$ \\
\hline 18 & Weight, humerus... & $0.820 \pm 0.012$ & 27 & Femur, humerus $\left(F_{2}\right.$ & \\
\hline 19 & Weight, femur... & $0.841 \pm 0.011$ & 28 & only) $\ldots \ldots \ldots \ldots$ & $0.878 \pm 0.010$ \\
\hline 20 & Weight, tibia. & $0.758 \pm 0.015$ & 28 & Tibia, humerus. . & $0.904 \pm 0.006$ \\
\hline 21 & Humerus, skull-length & $0.834 \pm 0.011$ & 29 & Tibia, femur...... & $0.927 \pm 0.005$ \\
\hline
\end{tabular}

TABLE 31.-Number of size factors indicated by each set of measurements as differentiating the three races crossed.

\begin{tabular}{|c|c|c|c|r|r|r|r|}
\hline Race. & Tibia. & Fenıur. & Humerus. & $\begin{array}{r}\text { Skull- } \\
\text { length. }\end{array}$ & Weight. & Ear-length. & Av. \\
\hline Polish-Himalayan.. & 2.1 & 2.6 & 1.0 & 3.1 & 1.6 & 1.5 & 2.0 \\
Himalayan-Flemish. & 9.8 & 7.3 & 4.8 & 7.0 & 9.7 & 10.6 & 8.2 \\
Polish-Flemish.... & 4.7 & 5.2 & 5.3 & 5.6 & 21.0 & 21.2 & 10.5 \\
\hline
\end{tabular}


TABLE 32.-Comparative size of the two sexes in the several groups of cross-bred rabbits.

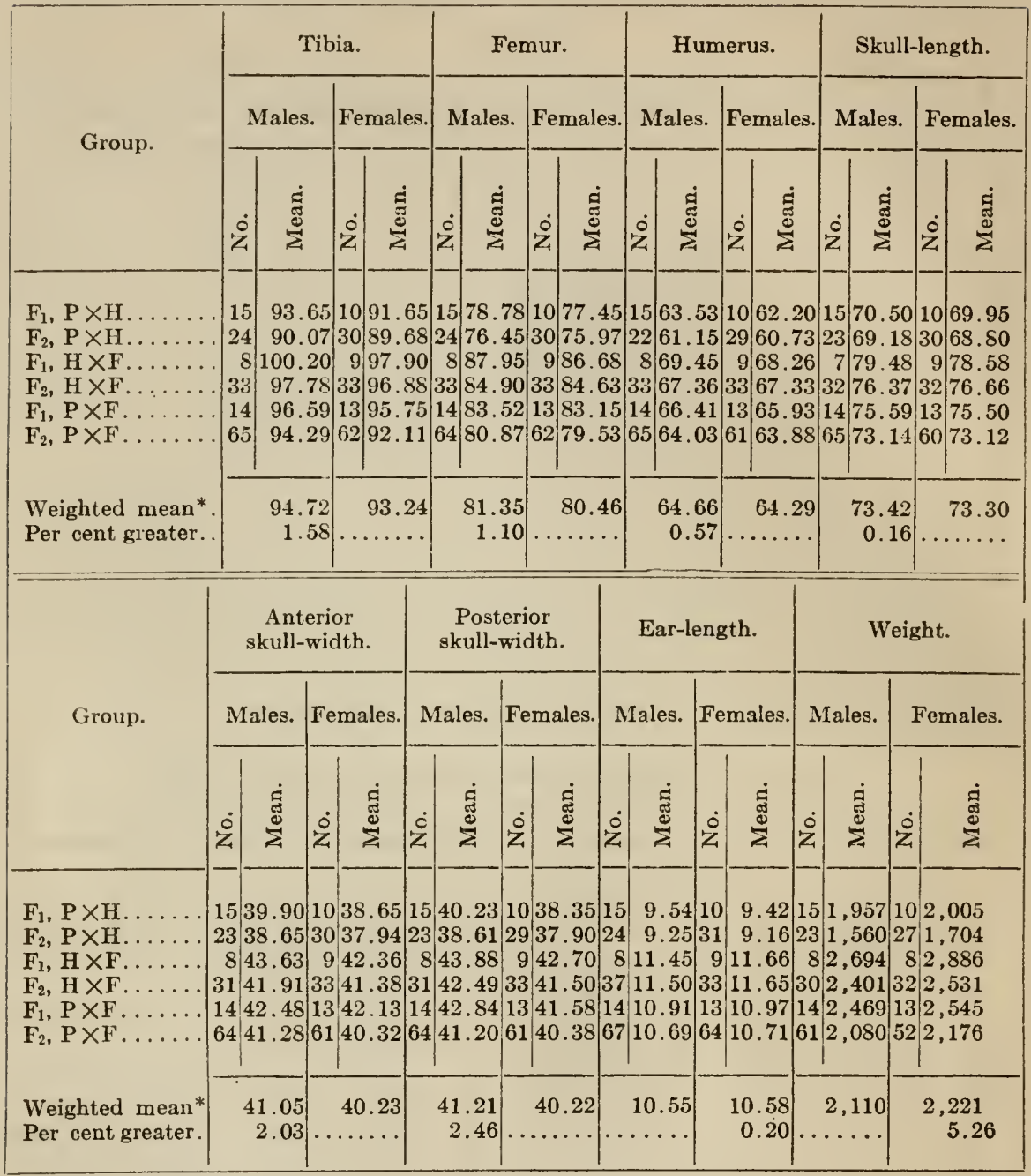

* The weighted means were obtained by counting each male mean the same number of times as each female mean, the number of individuals assumed for the purpose of the computation to occur in each sex of each gioup being as follows: $F_{1}, P \times H, 15 ; F_{2}, P \times H, 30 ; F_{1}, H \times F, 10$; $F_{2}, H \times F, 33 ; F_{1}, P \times F, 15 ; F_{2}, P \times F, 65$. 
TABLE 33.-Descriptive list of rabbits studied.

Abbreviations in column headed "color": A, snow-white albino; An, angora; B, black; Dil, dilute; G, gray; H, Himalayan albino: St. G, steel gray; $Y$, yellow. Measurements in millimeters; weight in grams.

I. Polisit, All Snow-white Albinos.

\begin{tabular}{|c|c|c|c|c|c|c|c|c|c|c|c|}
\hline Designation. & 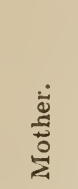 & 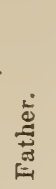 & Born. & 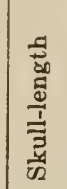 & 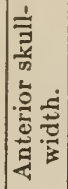 & 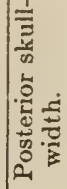 & $\underset{\mathrm{g}}{\mathrm{\Xi}}$ & 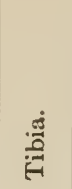 & 疍 & 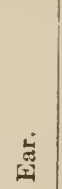 & 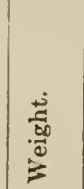 \\
\hline $\begin{array}{l}\$ 1 . \\
\$ 2 . \\
\$ 9 . \\
\$ 10 .\end{array}$ & & & & & & & & & & & \\
\hline † 2413 . & 1 & 3 & June 11,1917 & & & & & & & 8.4 & 1,275 \\
\hline$\$ 2712$. & 10 & 3 & Sept. 10, 1917 & 68.9 & 37.3 & 37.8 & 75.4 & 86.4 & 59.3 & 8.3 & 1,425 \\
\hline † 2713 . & 10 & 3 & Do. & 68.4 & 38.6 & 38.5 & 73.1 & 84.7 & 57.1 & & 1,545 \\
\hline$\uparrow 2738$. & 2 & 3 & Sept. 13, 1917 & 68.2 & 38.4 & 38.4 & 73.4 & 86.0 & 58.8 & 8.7 & 1,575 \\
\hline ○ 2753 . & 9 & 3 & Sept. 20, 1917 & 65.5 & 37.8 & 38.8 & 73.9 & 84.9 & 60.3 & 8.3 & 1,250 \\
\hline @ 3186 . & 2738 & 3 & June 14,1918 & 65.4 & 36.2 & 37.5 & 68.4 & 80.1 & 55.5 & 8.1 & 1,355 \\
\hline † 3187 . & 2738 & 3 & Do. & 66.2 & 36.5 & 37.8 & 70.5 & 80.7 & 57.0 & 8.7 & 1,295 \\
\hline \$ 3488 . & 2753 & 3 & Aug. 16, 1918 & & & & 71.0 & 81.4 & 57.3 & 8.1 & \\
\hline ㅇ 3489 . & 2753 & 3 & Do. & 63.6 & 36.5 & 37.8 & 71.5 & 84.5 & 58.2 & 8.5 & 1,230 \\
\hline \$3490. & 2753 & 3 & Do. & 63.6 & 37.5 & 37.4 & 69.9 & 79.9 & 56.7 & & 1,280 \\
\hline व'3. & & & & 69.3 & 41.0 & 40.5 & 76.4 & 89.6 & 60.9 & 8.5 & 1,700 \\
\hline $0^{7} 2312$. & 10 & 3 & May 28,1917 & 65.0 & 39.6 & 38.4 & 73.2 & 84.2 & 57.5 & 8.4 & 1,450 \\
\hline $0^{\top} 2313$. & 10 & 3 & Do. & & & & & & & 8.4 & \\
\hline$\sigma^{7} 2314$. & 10 & 3 & Do. & 65.6 & 39.2 & 38.9 & 72.5 & 83.6 & 57.2 & 8.4 & 1,505 \\
\hline $0^{2} 2412$. & 1 & 3 & June 11,1917 & 67.0 & 37.9 & 37.7 & 73.0 & 87.6 & 58.8 & & $\begin{array}{l}1,400 \\
1,40\end{array}$ \\
\hline$\sigma^{2} 2741$. & 2 & 3 & Sept. 13, 1917 & 63.4 & 38.7 & 38.7 & 72.9 & 82.7 & 57.7 & 8.2 & 1,450 \\
\hline $0^{2} 2742$. & 2 & 3 & Do. & 65.5 & 38.2 & 38.3 & 71.0 & 82.3 & 57.7 & & 1,450 \\
\hline$\sigma^{7} 2751$. & 9 & 3 & Sept. 20, 1917 & 67.1 & 36.8 & 37.1 & 73.3 & 83.6 & 57.6 & 8.1 & 1,200 \\
\hline o' 3318 & 2713 & 3 & June 17,1918 & 64.5 & 38.9 & 37.3 & 73.6 & 84.5 & 57.5 & 8.4 & 1,340 \\
\hline$\sigma^{\top} 3487$ & 2753 & 3 & Aug. 16, 1918 & 64.6 & 38.8 & 39.6 & 72.8 & 85.0 & 58.8 & 8.4 & 1,325 \\
\hline$\sigma^{7} 3561$ & 2712 & 3 & Aug. 21, 1918 & & & & & ..... & & 8.2 & \\
\hline
\end{tabular}

it. Himalayan, All "Himalayan" Albinos.

\begin{tabular}{|c|c|c|c|c|c|c|c|c|c|c|c|}
\hline Designation. & 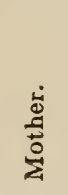 & 总 & Born. & 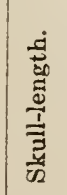 & 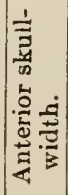 & 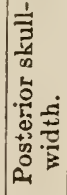 & 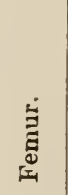 & $\stackrel{.00}{0}$ & 苞 & 馬 & $\frac{\vec{a}}{0}$ \\
\hline $\begin{array}{l}94 \\
\$ 6\end{array}$ & & & & 66.1 & 35.8 & 37.3 & 77.3 & 92.9 & 61.5 & & \\
\hline ஒ 2206 . & 4 & 5 & Apr. 27,1917 & $\begin{array}{l}72.9 \\
69.1\end{array}$ & $\begin{array}{l}39.6 \\
37.3\end{array}$ & $\begin{array}{l}40.2 \\
37.4\end{array}$ & $\begin{array}{l}82.8 \\
79.3\end{array}$ & $\begin{array}{l}95.9 \\
94.3\end{array}$ & $\begin{array}{l}63.9 \\
62.4\end{array}$ & $\begin{array}{l}9.7 \\
9.2\end{array}$ & $\mid \begin{array}{l}2,210 \\
2,085\end{array}$ \\
\hline$\$ 2210$. & & & Do. & 69.0 & 37.3 & 38.0 & 80.7 & 94.8 & 63.8 & 9.5 & 1,8 \\
\hline † 3565 & 2210 & 2208 & Aug. 21, 1918 & 67.5 & 35.9 & 37.4 & 77.8 & 92.1 & 63.9 & 9.5 & 1,620 \\
\hline $\begin{array}{r}3566 \ldots \\
0^{7} 5 \ldots\end{array}$ & 2210 & 2208 & Do. & $\begin{array}{l}66.9 \\
72.1\end{array}$ & $\begin{array}{l}35.3 \\
37.3\end{array}$ & 37.1 & $\begin{array}{l}77.0 \\
81.3\end{array}$ & $\begin{array}{l}92.9 \\
96.0\end{array}$ & $\begin{array}{l}62.8 \\
62.9\end{array}$ & 9.6 & 1,600 \\
\hline$\sigma^{7} 2208$ & 4 & 5 & Apr. 27,1917 & 69.1 & 38.2 & 39.2 & 80.0 & 93.0 & 63.6 & 9.4 & 1,850 \\
\hline
\end{tabular}


TABLE 33.-Descriptive list of rabbits studied-Continued.

ili. Flemish Giant.

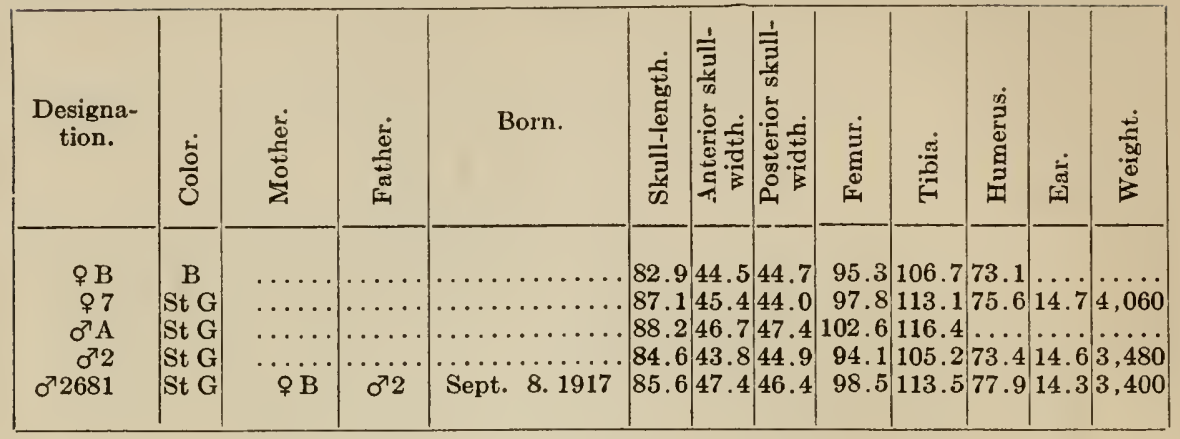

IV. $F_{1}$, Polish $\times$ Himalayan, All "Himalayan" Albinos.

\begin{tabular}{|c|c|c|c|c|c|c|c|c|c|c|c|}
\hline Designation. & 离 & 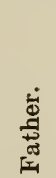 & Born. & 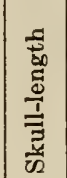 & 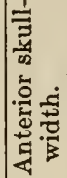 & 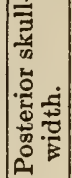 & 苞 & 苞 & 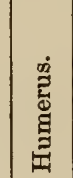 & تَّ & $\frac{\overrightarrow{0}}{00}$ \\
\hline ㅇ 2317 & $9 \mathrm{P}$ & $5 \mathrm{H}$ & May 28,1917 & 74.8 & 39.9 & 38.6 & 79.0 & 95.4 & 464.7 & 9.6 & 2,270 \\
\hline & $9 \mathrm{P}$ & $5 \mathrm{H}$ & Do. & 72.3 & 39.6 & 38.5 & 78.6 & 93.2 & 263.3 & 9.4 & 2,285 \\
\hline$\uparrow 2323$ & $4 \mathrm{H}$ & $3 \mathrm{P}$ & Do. & 70.5 & 38.7 & 38.5 & 79.0 & 93.7 & 763.7 & 9.6 & 1,940 \\
\hline † 2340 & $2 \mathrm{P}$ & $5 \mathrm{H}$ & ay 29,1 & 70.5 & 38.8 & 39.4 & 76.9 & 91.7 & 762.2 & 9.5 & $\mid 2,390$ \\
\hline \$234 & $2 \mathrm{P}$ & $5 \mathrm{H}$ & Do. & 70.8 & 39.8 & 39.6 & 77.8 & 92.7 & 63.0 & 9.7 & 2,495 \\
\hline ๆ 2395 & $6 \mathrm{H}$ & $3 \mathrm{P}$ & ne 4,1917 & 68.7 & 38.5 & 38.2 & 78.5 & 91.9 & 962.5 & 9.5 & 1,940 \\
\hline ○ 244 & $10 \mathrm{P}$ & $5 \mathrm{H}$ & June 28,1917 & 70.7 & 38.7 & 36.8 & 78.4 & 91.5 & 51.6 & 9.2 & 1,675 \\
\hline$\$ 30$ & $2206 \mathrm{H}$ & $3 \mathrm{P}$ & Apr. 27,1918 & 62.1 & 37.0 & 37.3 & 73.9 & 86.0 & 59.3 & & \\
\hline ○ 309 & $2210 \mathrm{H}$ & $3 \mathrm{P}$ & Do. & 67.8 & 36.9 & 37.5 & 75.4 & 89.2 & 60.7 & 9.4 & 1,540 \\
\hline ㅇ․ 3 & $2210 \mathrm{H}$ & $3 \mathrm{P}$ & Do. & 71.4 & 38.8 & 38.7 & 77.9 & 91.8 & 860.9 & 9.3 & 1,825 \\
\hline $0^{7} 2$ & $9 \mathrm{P}$ & $5 \mathbf{H}$ & May 28,1917 & 74.5 & 51.0 & 40.2 & 79.9 & 96.5 & 564.6 & 9.7 & 2,145 \\
\hline & $9 \mathrm{P}$ & $5 \mathrm{H}$ & Do. & 70.4 & 39.0 & 38.8 & 78.4 & 92.9 & 963.0 & 9.5 & 1,945 \\
\hline 0 & $9 \mathrm{P}$ & $5 \mathrm{H}$ & Do. & 72.7 & 40.2 & 40.0 & 78.0 & 93.4 & 462.8 & 9.3 & 1,770 \\
\hline & $4 \mathrm{H}$ & $3 \mathrm{P}$ & May 28,1917 & 69.0 & 39.4 & 39.6 & 77.9 & 93.9 & 962.6 & 9.5 & 1,835 \\
\hline 0 & $4 \mathrm{H}$ & $3 \mathrm{P}$ & Do. & 71.0 & 40.7 & 40.9 & 79.7 & 96.8 & 83.7 & 9.5 & 1,920 \\
\hline & $4 \mathrm{H}$ & $3 \mathrm{P}$ & & 71.7 & 40.9 & 40.6 & 82.0 & 96.8 & 865.1 & 9.7 & 2,060 \\
\hline & $2 \mathrm{P}$ & $5 \mathrm{H}$ & May 29,1917 & 68.1 & 39.4 & 40.2 & 76.5 & 91.2 & 262.7 & 9.4 & 1,945 \\
\hline & $2 \mathrm{P}$ & $5 \mathrm{H}$ & Do. & 68.5 & 38.9 & 37.8 & \begin{tabular}{|l|}
75.5 \\
\end{tabular} & 90.3 & 61.9 & 9.4 & 1,945 \\
\hline & $2 \mathrm{P}$ & $5 \mathrm{H}$ & Do. & 70.9 & 40.4 & 40.5 & 77.3 & 92.7 & 62.4 & 9.8 & 2,110 \\
\hline & $6 \mathrm{H}$ & $3 \mathrm{P}$ & June 4,1917 & 68.5 & 41.8 & 42.7 & 78.9 & 91.7 & 62.4 & 9.4 & 2,175 \\
\hline & $6 \mathrm{H}$ & $3 \mathrm{P}$ & Do. & 71.3 & 40.9 & 41.4 & 81.9 & 96.8 & 64.5 & 9.7 & 2,045 \\
\hline & $6 \mathrm{H}$ & $3 \mathbf{P}$ & Do. & 70.6 & 39.3 & 39.4 & 78.7 & 92.9 & 62.5 & 9.6 & 1,865 \\
\hline & $6 \mathrm{H}$ & $3 \mathrm{P}$ & Do & 70.8 & 39.9 & 40.7 & 80.5 & 94.0 & 63.7 & 9.5 & 1,870 \\
\hline & $6 \mathrm{H}$ & $3 \mathrm{P}$ & Do & 70.7 & 40.6 & 41.0 & 80.7 & 95.5 & 63.8 & 9.5 & 2,000 \\
\hline$\sigma^{7} 310$ & $2210 \mathrm{H}$ & $3 \mathrm{P}$ & Apr. 27,1918 & 68.4 & 38.4 & 39.9 & 77.4 & 91.6 & 62.8 & 9.6 & 1,735 \\
\hline
\end{tabular}


TABLE 33.-Descriptive list of rabbits studied-Continued.

V. $F_{1}$, Polish $\times$ Flemish.

\begin{tabular}{|c|c|c|c|c|c|c|c|c|c|c|c|c|}
\hline $\begin{array}{c}\text { Designa- } \\
\text { tion. }\end{array}$ & Color. & 总 & 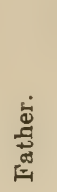 & Born. & 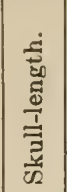 & 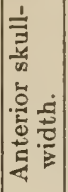 & 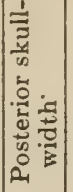 & 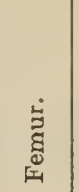 & 莡 & 总 & 茎 & 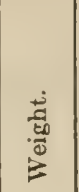 \\
\hline @ 2430 & G & $7 F$ & $3 \mathrm{P}$ & Ine 29,1 & 74.6 & 42.8 & 41.8 & 86.2 & 99.1 & $66.0 \mid$ & 11.1 & 2,680 \\
\hline o & $\mathrm{St} \mathrm{G}$ & 7. & 3 & Do. & 74.7 & 41.8 & 42.7 & 81.8 & 92.1 & 64.9 & 11.2 & 2,500 \\
\hline q & B & 7. & & Do. & 77.0 & 42.3 & 42.8 & 83.3 & 96.8 & 65.0 & 11.2 & $2,500 \mid$ \\
\hline q & $\mathrm{G}$ & 7. & 3 & Do. & 74.3 & 42.1 & 40.5 & 84.1 & 98.5 & 65.8 & 10.3 & 2,300 \\
\hline 92 & $\mathrm{G}$ & 71 & 3 & Do. & 76.3 & 42.4 & 41.8 & 83.7 & 96.8 & 65.0 & 11.0 & $2,500 \mid$ \\
\hline$\$ 2$ & $\mathrm{G}$ & $9 \mathrm{P}$ & $2 \mathrm{~F}$ & July 7,1917 & 76.3 & 42.8 & 41.5 & 83.3 & 96.8 & 67.9 & 11.0 & 2,300 \\
\hline ㅇ 24 & $\mathrm{~B}$ & $\mathrm{BF}$ & 3. & July 8,1917 & 74.5 & 40.0 & 39.7 & 83.7 & 95.9 & 66.6 & 11.3 & 2,055 \\
\hline$\& 2507$ & St G & $2 \mathrm{P}$ & $2 \mathrm{~F}$ & July 19,1917 & 75.3 & 42.4 & 41.7 & 81.7 & \begin{tabular}{|l|}
93.7 \\
\end{tabular} & 65.8 & 11.1 & $2,730 \mid$ \\
\hline фo & & 2 & $2 \mathrm{~F}$ & Do. & 74.4 & 41.6 & 42.3 & 81.5 & 94.0 & 65.4 & 11.3 & 2,715 \\
\hline o & & 2 & $2]$ & Do. & 6.0 & 42.0 & 40.9 & 82.8 & 97.0 & 65.3 & 11.1 & 2,545 \\
\hline & $\mathrm{S}$ & 2 & 2 & Do & 75.7 & 43.2 & 42.3 & 82.9 & 94.4 & 66.8 & 10.8 & 2,890 \\
\hline 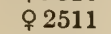 & $\mathrm{St}$ & 2 & & Do & 3 & 41.9 & 41.4 & 82.3 & 93.7 & .8 & 10.9 & 2,660 \\
\hline q & G & 1 . & 2. & July 26,1917 & 76.2 & 42.8 & 41.7 & 84.0 & 96.0 & 4 & 10.3 & 2,720 \\
\hline$\sigma^{2}$ & $\mathrm{G}$ & & 3 & June 29,1 & 74.7 & 41.2 & 41.5 & 81.8 & 96.2 & & 10.3 & 2,385 \\
\hline & St G & 7 & 3 & Do. & 76.9 & 43.7 & 43.9 & 85.4 & 99.9 & 67.5 & 11.0 & 2,735 \\
\hline & B & 7 & & Do & 3.2 & 41.8 & 43.0 & 84.9 & 98.7 & 66.7 & 1 & 2,525 \\
\hline & $\mathrm{G}$ & 7 & 3. & Do & 74.3 & 42.5 & 42.8 & 85.8 & 100.2 & 67.0 & 10 & 2,526 \\
\hline & St G & 9] & 21 & Juls & 75.8 & 41.7 & 42.6 & 84.8 & 100.5 & 6 & 1 & 2,380 \\
\hline & & $\mathrm{B}$ & 3 & July 8,1 & 79.8 & 44.4 & 44.4 & 86.7 & 98.7 & 8 & 1 & 2,670 \\
\hline & St & $2 \mathbf{P}$ & $2 \mathrm{~F}$ & July 19, & 73.8 & 42.6 & 43.0 & 80.1 & 92.7 & 6 & 1 & 2,350 \\
\hline & & 1] & $2 \mathrm{~F}$ & July 26,1 & 77.2 & 42.2 & 41.9 & 84.0 & 96.2 & & 1 & 2,500 \\
\hline & St G & 1) & $2 \mathrm{~F}$ & Do. & 73.0 & 42.3 & 42.0 & 82.1 & 94.5 & 64. & 10. & 2,160 \\
\hline & G & 9 & $2 \mathrm{~F}$ & Aug. 9, & 75.5 & 42.7 & 42.8 & 82.0 & 95.4 & 65.5 & & 2,500 \\
\hline & G & $10 \mathrm{P}$ & $2 \mathrm{~F}$ & Dec. 7,1917 & 75.9 & 43.1 & 42.6 & 85.2 & 96.2 & 67. & 10. & 2,445 \\
\hline & c & 2 & $2 \mathrm{~F}$ & Dec. 9,1917 & 75.5 & 42.8 & 44.1 & 83.9 & 94.7 & 67.8 & 11 & 2,400 \\
\hline & $G$ & $2 \mathrm{P}$ & $2 \mathrm{~F}$ & Do. & 75.0 & 41.8 & 42.5 & 82.8 & 95.3 & 66.7 & & 2,650 \\
\hline$\sigma^{2} 2867$ & St G & $2 \mathrm{P}$ & $2 F$ & Do. & & 42.0 & 42.1 & 80.7 & 93.2 & & 1 & 2,35 \\
\hline
\end{tabular}

VI. $F_{1}$, Himalayan $\times$ Flemish.

\begin{tabular}{|c|c|c|c|c|c|c|c|c|c|c|c|c|}
\hline $\begin{array}{l}\text { Designa- } \\
\text { tion. }\end{array}$ & Color. & & 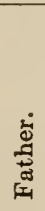 & Born. & 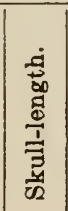 & 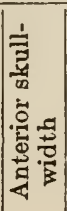 & 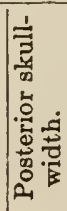 & 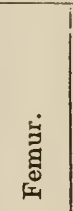 & 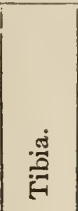 & 总 & สี & $\frac{\vec{c}}{\overrightarrow{0}}$ \\
\hline 우 2517 & St G & $4 \mathrm{H}$ & $2 F$ & July 19,1917 & 76.4 & $|42.4|$ & $\mid 42.9$ & 86.6 & $99.8>>25$ & 69.3 & 11.8 & 3,040 \\
\hline & $\mathrm{G}$ & $4 \mathrm{H}$ & $2 \mathrm{~F}$ & Do. & 78.7 & 42.8 & 43.4 & 85.1 & 97.5 & 67.0 & 11.8 & 2,800 \\
\hline 우 2521 & G & $4 \mathrm{H}$ & $2 \mathrm{~F}$ & Do. & 80.0 & 43.1 & 42.1 & 88.4 & 102.1 & 71.1 & 11.5 & 3,060 \\
\hline$\$ 2642$ & St $G$ & $6 \mathrm{H}$ & $2 \mathrm{~F}$ & Aug. 9,1917 & 79.5 & 42.8 & 43.5 & 88.7 & 99.7 & 69.0 & 11.8 & 2,800 \\
\hline ○ 2645 & St G & $6 \mathrm{H}$ & $2 \mathrm{~F}$ & Do. & 78.8 & 43.5 & 42.7 & 86.5 & 96.8 & 67.0 & 11.8 & 2,800 \\
\hline † 2646 & G & $6 \mathrm{H}$ & $2 \mathrm{~F}$ & Do. & 81.5 & 43.4 & 43.2 & 86.2 & 97.2 & 67.8 & 11.6 & 2,765 \\
\hline ㅇ 2828 & St G & $6 \mathrm{H}$ & $2 \mathrm{~F}$ & Dec. 7,1917 & 76.3 & 41.8 & 40.9 & 84.8 & 95.0 & 66.2 & 11.3 & 2.775 \\
\hline 우 2830 & G & $6 \mathrm{H}$ & $2 \mathrm{~F}$ & Do. & 79.9 & 42.3 & 43.7 & 88.7 & 97.8 & 68.4 & 11.9 & 3,050 \\
\hline ㅇ 2832 & St G & $6 \mathrm{H}$ & $2 F$ & Do. & 76.3 & 39.7 & 42.0 & 85.0 & 95.5 & 68.3 & 11.5 & \\
\hline$\sigma^{3} 2518$ & G & $4 \mathrm{H}$ & $2 \mathrm{~F}$ & July 19,1917 & 78.6 & 42.3 & 43.1 & 88.1 & 99.9 & 71.0 & 11.3 & 2,440 \\
\hline$\sigma^{2} 25$ & St G & $4 \mathrm{H}$ & $2 \mathrm{~F}$ & Do. & 77.6 & 43.8 & 44.2 & 86.8 & 100.9 & 69.1 & 11.5 & 2,775 \\
\hline$\sigma^{7} 2522$ & $G$ & $4 \mathrm{H}$ & $2 \mathrm{~F}$ & Do. & 79.6 & 44.6 & 44.1 & 88.4 & 101.0 & 69.4 & 11.7 & 2,875 \\
\hline $0^{7}$ & St G & $6 \mathrm{H}$ & $2 \mathrm{~F}$ & Aug. 9,1917 & 82.8 & 46.3 & 44.4 & 91.9 & 105.0 & 70.9 & 11.4 & 2,900 \\
\hline 644 & St G & $6 \mathrm{H}$ & $2 \mathrm{~F}$ & Do. & 79.3 & 41.7 & 43.9 & 86.2 & 98.1 & 68.8 & 11.4 & 2,550 \\
\hline & G & $6 \mathrm{H}$ & $2 \mathrm{~F}$ & Do. & 80.4 & 43.2 & 44.0 & 88.2 & 99.0 & 68.6 & 11.7 & 2,600 \\
\hline$\sigma^{2} 2$ & G & $6 \mathrm{H}$ & $2 \mathrm{~F}$ & Do. & & 44.5 & 44.6 & 87.4 & 98.6 & 68.7 & 11.4 & 2,665 \\
\hline$\sigma^{7} 2649$ & G & $6 \mathrm{H}$ & $2 \mathrm{~F}$ & Do. & 78.2 & 42.7 & 43.0 & 86.8 & 98. & 69.3 & 11. & 2,750 \\
\hline
\end{tabular}


TABLE 33.-Descriptive list of rabbits studied-Continued.

viI. $F_{2}$, Polish $\times$ Himalayan.

\begin{tabular}{|c|c|c|c|c|c|c|c|c|c|c|c|c|}
\hline $\begin{array}{c}\text { Designa- } \\
\text { tion. }\end{array}$ & Color. & 兽 & 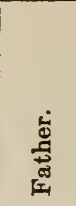 & Born. & 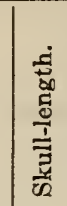 & 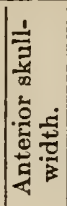 & 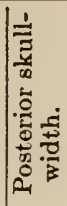 & 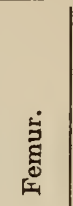 & : & 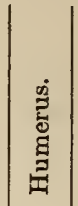 & 离 & 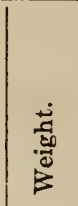 \\
\hline ९ 2915 & H & 2323 & 2324 & Apr. 16,1918 & 68.9 & 38.1 & 38.4 & 77.7 & 90.7 & 61.5 & 9.5 & 1,880 \\
\hline$\$ 2916$ & A & 2323 & 2324 & Do. & 65.6 & 35 & 36.5 & 74.6 & 87.6 & 58.5 & 9.1 & 1,230 \\
\hline † 2993 & $\mathbf{H}$ & 2446 & 2342 & Apr. 18,1918 & 65.3 & 36.4 & & 74.4 & 87.4 & 60.6 & 8.8 & \\
\hline$\$ 3028$ & A & 2320 & 2316 & Apr. 21,1918 & 75.0 & 39.5 & 38.7 & 80.2 & 96.2 & 63.9 & 9.5 & 1,800 \\
\hline 3029 & A & 2320 & 2316 & Do. & 69.1 & 37.8 & 37.5 & 75.7 & 91.4 & 61.2 & 9.2 & 1,515 \\
\hline$\$ 3173$ & $\mathrm{H}$ & 2320 & 2316 & June 14,1918 & 70.3 & 35.9 & 35.7 & 78.7 & 91.4 & 62.1 & 9.5 & 1,490 \\
\hline$\$ 3426$ & $\mathbf{H}$ & 2317 & 2316 & July 4,1918 & 72.5 & 36.5 & 36.9 & 77.8 & 91.0 & 62.1 & 9.5 & 1,425 \\
\hline$\$ 3427$ & $\mathrm{H}$ & 2317 & 2316 & Do. & 67.7 & 36.9 & 37.0 & 76.7 & 91.0 & 62.0 & 9.2 & \\
\hline 3428 & $\mathrm{H}$ & 2317 & 2316 & Do. & 72.5 & 38.4 & 37.8 & 76.6 & 90.7 & 61.5 & 9.1 & 1,685 \\
\hline$\$ 3544$ & A & 2323 & 2324 & Aug. 15,1918 & 70.4 & 39.2 & 39.5 & 79.3 & 92.7 & 64.5 & 9.5 & 1.700 \\
\hline$\$ 3545$ & A & 2323 & 2324 & Do. & 70.1 & 40.0 & 39.6 & 80.5 & 94.3 & 64.9 & 9.7 & 1,980 \\
\hline$\$ 3610$ & $\mathbf{H}$ & 2446 & 2316 & Sept. 1,1 & 69.6 & 36.9 & 36.9 & 75.7 & 89.0 & 60.8 & 8.8 & 1,750 \\
\hline 3611 & $\mathrm{H}$ & 2446 & 2316 & Do. & 65.3 & 37.3 & 37.3 & 73.3 & 86.4 & 58.3 & 8.5 & \\
\hline ○ 3629 & H (Blue) & 2320 & 2344 & Nov. 2,1 & 71.6 & 40.5 & 39.2 & 77.8 & 92.7 & 61.5 & 8.9 & 2,170 \\
\hline † 3633 & H (Blue) & 2320 & 2344 & Do. & 67.2 & 37.4 & 37.8 & 76.7 & 92.7 & 62.4 & 9.1 & 1,705 \\
\hline † 3634 & A & 2320 & 2344 & Do. & 70.6 & 39.6 & 39.3 & 76.9 & 81.4 & 63.1 & 9.2 & 1,715 \\
\hline † 3637 & H (Blue) & 2317 & 2344 & Do. & 69.1 & 39.9 & 39.4 & 78.7 & 92.7 & 63.7 & 9.9 & 2,325 \\
\hline$\$ 3638$ & $\mathrm{H}$ & 2317 & 2344 & Do. & 70.4 & 36.8 & 37.1 & 77.7 & 92.8 & 62.4 & 9.1 & 1,900 \\
\hline † 3641 & A & 2317 & 2344 & Do. & & & & & & & 8.9 & \\
\hline$\$ 4079$ & $\mathbf{H}$ & 2323 & 2324 & Apr. 3,1919 & 67.2 & 38.5 & 37.5 & 76.9 & 89.4 & 60.5 & 9.8 & 1,465 \\
\hline$\uparrow 4193$ & $\mathrm{H}$ & 3094 & 2324 & May 26,1919 & 70.2 & 39.7 & 38.1 & 77.2 & 90.6 & 61.8 & 9.8 & 1,985 \\
\hline$\$ 4194$ & A & 3094 & 2324 & Do. & 69.6 & 38.9 & 38.5 & 77.3 & 89.8 & 61.9 & 9.2 & 1,810 \\
\hline$\$ 4196$ & $\mathrm{H}$ & 3099 & 2324 & Do. & 68.8 & 39.3 & 38.5 & 77.5 & 90.9 & & 9.8 & 1,615 \\
\hline \$ 4201 & A & 2320 & 2344 & June 3,1919 & 66.0 & 36.5 & 37.3 & 68.4 & 80.4 & 54.6 & 8.3 & 1,520 \\
\hline$\$ 42$ & A & 2320 & 2344 & Do & 68.9 & & 39.3 & 73.4 & 86.5 & 57.6 & 9.0 & 1,865 \\
\hline$\$ 4204$ & $\mathrm{H}$ & 2320 & 2344 & Do. & 65.5 & $37.9 \mid$ & 37.3 & 73.0 & 85.8 & 58.3 & 8.7 & 1,600 \\
\hline$\$ 4205$ & $\mathrm{H}$ & 2320 & 2344 & Do & 65.9 & & & 74.1 & 88.0 & 56.5 & 8.8 & 1,620 \\
\hline$\$ 4207$ & H & 2320 & 2344 & Do. & 68.2 & 37.5 & 38.8 & 74.3 & 86.4 & 59.5 & 9.2 & 1,825 \\
\hline$\$ 42$ & $\bar{H}$ & 2320 & 2344 & Do & 67.2 & 38.1 & 37.7 & 69.8 & 82.3 & 54.9 & 8.9 & 1,530 \\
\hline$\$ 4270$ & $\mathrm{H}$ & 2323 & 2324 & July 25,1919 & 65.4 & 37.2 & $|37.1|$ & 75.0 & 89.4 & 60.2 & 8.7 & 1,300 \\
\hline 3 & A & 2446 & 2344 & July 26,1919 & 69.5 & 37.9 & 37.8 & 75.6 & 89.5 & 59.5 & 8.8 & 1,600 \\
\hline$\sigma^{\circ}$ & $\mathrm{H}$ & 2320 & 2 & June 14,1918 & 68.8 & $|37.5|$ & $36.7 \mid$ & 74.8 & 88.2 & 60.4 & 9.7 & 1,340 \\
\hline$\sigma^{7} 3171$ & $\mathrm{H}$ & 2320 & 2316 & Do. & 68.8 & 38.0 & 38.2 & 76.0 & 89.4 & 60.3 & 8.9 & 1.395 \\
\hline $0^{\circ}$ & $\mathbf{H}$ & 20 & 2 & Do. & & & & 78.2 & 88.0 & & 9.4 & \\
\hline$\sigma^{7} 3231$ & $\mathbf{H}$ & 2395 & 2324 & Do. & 68.9 & 38.5 & 38.9 & 74.6 & 86.3 & 59.8 & 9.2 & 1,505 \\
\hline $0^{\circ}$ & $\mathbf{H}$ & 7 & 2 & July 4,1 & 71.7 & 40.0 & $|39.5|$ & 77.0 & 92.0 & 62.3 & 9.5 & 1,655 \\
\hline$\sigma^{7} 3542$ & A & 23 & 2324 & Aug. 15, 1918 & 65.1 & 38.7 & $38.9 \mid$ & 76.6 & 90.6 & 60.2 & 9.0 & 1,630 \\
\hline $0^{\circ}$ & $H_{2}$ & & 2 & Do. & 69.6 & 39.8 & 40.0 & 79.6 & 94.6 & 63.6 & 9.4 & 1,620 \\
\hline$\sigma^{7} 3609$ & $\mathrm{H}$ & 2446 & 2316 & Sept. 1, 1918 & 71.1 & 40.0 & $|39.7|$ & 78.0 & 90.4 & 61.7 & 9.3 & 1,910 \\
\hline & $A$ & & & Nov. 2,1918 & 71.5 & $|38.5|$ & $38.2 \mid$ & 80.1 & 94.3 & 63.9 & 9.4 & 1,820 \\
\hline$\sigma^{7} 3632$ & $\mathbf{H}$ & 2320 & 2344 & Do. & 70.9 & 39.2 & 38.9 & 78.6 & 94.2 & 63.2 & 9.3 & $1,770 \mid$ \\
\hline & H & & & D & 67.6 & $37.4 \mid$ & $37.3 \mid$ & 77.0 & 93.5 & 62.9 & 9.2 & 1,410 \\
\hline $0^{\circ}$ & $\mathbf{H}$ & 2317 & 2 & Do & 70.8 & 39.5 & $39.4 \mid$ & 77.8 & 93.5 & 63.7 & 9.2 & 1,585 \\
\hline & H & & & D & 71.6 & 39.7 & 38.8 & 78.4 & 94.1 & 63.8 & 9.7 & 1,720 \\
\hline$\sigma^{7}$ & A & 17 & 2 & D & 72.0 & 40.5 & 40.4 & 78.6 & 93.4 & 63.7 & 9.4 & 1,890 \\
\hline & H & & 23 & May 26,1919 & 67.3 & $|36.9|$ & 35.9 & 73.5 & 86.9 & $58.7 \mid$ & 9.1 & 1,390 \\
\hline $0^{7} 4199$ & H & 99 & 2 & Do. & 69.0 & $38.6 \mid$ & 37.4 & 76.6 & 90.6 & 62.4 & 8.9 & 1,375 \\
\hline & A & & 2344 & June 3,1 & 67.6 & $38.9 \mid$ & 38.6 & 73.3 & 85.7 & 58.2 & 9.3 & 1,610 \\
\hline$\sigma^{7} 4206$ & H & 20 & 2344 & Do. & 68.2 & 40.2 & 39.6 & 72.3 & 83.7 & 56.7 & 9.5 & 1,600 \\
\hline & H & & & Do. & 68.3 & 38.0 & 38.7 & 73.7 & 86.6 & 58.2 & 9.3 & 1,435 \\
\hline $0^{7} 4265$ & H (Blue) & 2323 & 2324 & July 25,1919 & 68.8 & 39.4 & 38.4 & 78.8 & 91.5 & & 9.0 & 1,510 \\
\hline & A & 2323 & 2324 & Do. & 71.1 & 39.2 & 40.0 & 78.7 & 94.2 & 62.6 & 9.7 & 1,500 \\
\hline & $\mathrm{H}$ & 2323 & 2324 & Do. & 65.0 & 36.3 & 36.0 & 73.1 & 84.9 & 60.8 & 8.4 & 1,090 \\
\hline$\sigma^{7} 4332$ & A & 2446 & 2344 & June 26,1 & 67.9 & 36.8 & 36.4 & 74.0 & 86.8 & 59.8 & 8.9 & 1,400 \\
\hline $0^{7} 4334$ & A & 2446 & 2344 & Do & 69.0 & 38.2 & 38.3 & 75.3 & 88.8 & 59.5 & 9.3 & 1,715 \\
\hline
\end{tabular}


TABLE 33.-Descriptive list of rabbits studied-Continued.

VIII. $F_{2}$, POLISH $\times$ FLEMISH.

\begin{tabular}{|c|c|c|c|c|c|c|c|c|c|c|c|c|}
\hline $\begin{array}{c}\text { Designa- } \\
\text { tion. }\end{array}$ & Color. & 芯 & 总 & Born. & 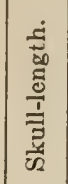 & 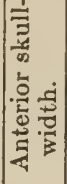 & 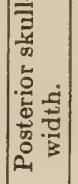 & 壳 & $\stackrel{\frac{\pi}{0}}{\stackrel{0}{*}}$ & 宽 & ตี & $\begin{array}{l}\overrightarrow{0} \\
\overrightarrow{0} \\
\vec{E}\end{array}$ \\
\hline ○ 2908 & $A$ & 2436 & 2434 & Apr. 16,1918 & 76.3 & 41.7 & 39.6 & 83.4 & 95.5 & 63.7 & 10.0 & 2,060 \\
\hline @ 2909 & $\mathrm{Y}$ & 2436 & 2434 & Do. & & & & & & & 10.4 & \\
\hline ○ 2918 & B & 2509 & 2506 & Apr, 17,1918 & 71.6 & 41.6 & 41.6 & 80.3 & 92.8 & 63.8 & 11.1 & $2,490 \mid$ \\
\hline$\$ 2920$ & St G & 2509 & 2506 & Do. & 70.5 & 39.5 & 40.2 & 80.0 & 93.7 & 64.8 & 11.3 & \\
\hline \& 2929 & St $G$ & 2451 & 2506 & Do. & 72.8 & 41.5 & 40.8 & 80.3 & 91.6 & 64.6 & 10.7 & 2,400 \\
\hline ㅇ 2932 & A & 2451 & 2506 & Do. & 73.3 & 40.3 & 40.2 & 79.3 & 92.5 & 65.3 & 10.5 & 2,430 \\
\hline 우 2943 & B An & 2430 & 2434 & Do. & 75.6 & 40.5 & 38.6 & 82.3 & 96.8 & 65.3 & 11.5 & $2,150 \mid$ \\
\hline 우 3002 & B & 2576 & 2506 & Apr. 19,1918 & 74.5 & 41.7 & 41.7 & 83.2 & 95.2 & 66.4 & 11.9 & \\
\hline \& 3004 & A & 2576 & 2506 & Do. & 73.0 & 40.9 & 39.8 & 79.0 & 91.8 & 64.0 & 9.8 & 2,055 \\
\hline$\$ 3008$ & St G & 2510 & 2506 & Do. & 73.0 & 40.0 & 38.7 & 79.6 & 90.7 & 63.2 & 10.8 & \\
\hline ๑ 3009 & G & 2510 & 2506 & Do. & 67.9 & 39.5 & 39.7 & 77.7 & 90.2 & 63.3 & 10.3 & \\
\hline \$3 3010 & Blue G & 2510 & 2506 & Do. & 73.5 & 41.6 & 40.7 & 77.4 & 92.1 & 63.4 & 11.2 & 2,365 \\
\hline \& 3011 & St Blue & 2510 & 2506 & Do. & 77.2 & 41.4 & 40.7 & 79.1 & 91.9 & 63.7 & 10.8 & 2,175 \\
\hline \$ 3108 & St G & 2474 & 2473 & May 6,1918 & 73.9 & $39.3 \mid$ & 38.8 & 80.6 & 92.8 & 62.9 & 10.2 & 1,900 \\
\hline † 3111 & St G & 2474 & 2473 & Do. & 70.8 & $39.0 \mid$ & 38.7 & 79.4 & 92.6 & 63.7 & 10.1 & 1,765 \\
\hline$\$ 3112$ & - Blue & 2474 & 2473 & Do. & 73.3 & 40.0 & 38.9 & 77.7 & 89.7 & 63.2 & 11.1 & 2,150 \\
\hline ९ 3159 & A & 2511 & 2506 & June 14,1918 & 65.9 & 37.9 & 38.8 & 72.9 & 85.0 & 58.1 & 9.7 & \\
\hline$\$ 3160$ & St G & 2511 & 2506 & Do. & 72.6 & 40.4 & 42.5 & 77.7 & 87.8 & 63.4 & 10.9 & 2,440 \\
\hline$\$ 316$ & St G & 511 & 2506 & Do. & 75.6 & 40.8 & 40.8 & 83.7 & 95.3 & 67.3 & $\mid 11.8$ & $2,460 \mid$ \\
\hline$\$ 3192$ & St G & 2430 & 2434 & June 14,1918 & 67.0 & 37.5 & 37.1 & 74.6 & 87.0 & 58.1 & 9.6 & 1,760 \\
\hline$\$ 315$ & G & 430 & 2434 & Do. & 74.2 & 40.7 & 40.7 & 83.8 & 99.0 & 65.8 & 10.8 & 2,420 \\
\hline$\$ 3201$ & A & 576 & 2506 & Do & 72.8 & 40.5 & 40.4 & 80.0 & 89.8 & 62.1 & 10.2 & 2,340 \\
\hline १ 3209 & A & 509 & 2506 & Do & 71.9 & 40.3 & 39.9 & 74.6 & 86.5 & 61.3 & 10.4 & 1,950 \\
\hline$\$ 3210$ & St G & 509 & 2506 & Do & 70.9 & 40.3 & 41.7 & 75.2 & 85.4 & 60.7 & 11.1 & 2,070 \\
\hline १ 32 & B & 509 & 2506 & Do. & 70.3 & 40.8 & 40.7 & 82.1 & 94.7 & 65.5 & 11.1 & \\
\hline$\$ 3240$ & G & 2451 & 2506 & June 15,1918 & 63.7 & 38.7 & 39.5 & 72.8 & 82.8 & 58.5 & 9.9 & 1,700 \\
\hline † 3301 & St G & 436 & 2434 & June 16,1918 & 75.0 & 41.6 & 41.3 & 82.9 & 94.9 & 65.9 & 10.2 & 2,670 \\
\hline \$ 3370 & A & 437 & 2434 & July 18,1918 & 77.5 & 42.0 & 40.8 & 81.9 & 94.5 & 64.5 & 10.8 & 2,050 \\
\hline$\uparrow 3371$ & A & 2437 & 2434 & Do. & 72.7 & 38.9 & 39.9 & 78.0 & 90.1 & 61.7 & 10.7 & $2,050 \mid$ \\
\hline \$3377 & St Blue & 2508 & 2506 & July 20,1918 & 73.0 & 40.0 & 40.7 & 77.3 & 91.0 & 62.9 & 10.6 & 1.810 \\
\hline १ 3379 & B & 2508 & 2506 & Do. & 69.6 & 38.7 & 39.8 & 76.8 & 88.9 & 64.3 & $3 \mid 9.8$ & 1.840 \\
\hline † 3397 & B & 2510 & 2506 & July 23,1918 & 77.4 & 42.0 & 42.3 & 82.0 & 95.0 & 67.1 & 10.8 & 2,325 \\
\hline$\$ 342$ & Blue & 2474 & 2473 & July $\quad 4,1918$ & 71.2 & 39.5 & 39.8 & 81.1 & 94.8 & 66.7 & 10.6 & 2,075 \\
\hline ९ 3423 & St $\mathrm{G}$ & 2474 & 2473 & Do. & 75.8 & 40.3 & 40.3 & 84.7 & 99.0 & 68.7 & 11.1 & 2,140 \\
\hline १ 344 & A & 2451 & 2506 & Aug. 16, 1918 & 76.3 & 42.2 & 41.3 & 78.2 & 89.8 & 64.0 & 11.2 & 2,200 \\
\hline$\$ 3450$ & St G & 2451 & 2506 & Do. & & & & & & & & \\
\hline$\$ 347$ & A & 576 & 2506 & Dc & & & & & & & 9.8 & \\
\hline$\$ 3479$ & $\mathrm{G}$ & 2576 & 2506 & D & & & & & & & 9.7 & \\
\hline$\$ 3511$ & A & 509 & 2506 & $\mathrm{D}$ & 75.5 & 42.3 & 43.3 & 78.9 & 88.5 & 62.9 & 11.1 & 2.475 \\
\hline$\$ 3513$ & St G & 0 & 50 & & 70.8 & 37.6 & 40.9 & 76.0 & 87.7 & 6 & 10.7 & 1.795 \\
\hline$\$ 352$ & St G & 511 & 2506 & $\mathrm{D}$ & 77.0 & 41.8 & 41.8 & 82.6 & 93.8 & 65.7 & 11.1 & 2,675 \\
\hline † 3528 & B & 1 & 250 & & 76.2 & 41.8 & 41.2 & 82.8 & 95. & 66.8 & 10.9 & 2,250 \\
\hline 3531 & A & 511 & 250 & D & 77.3 & 41.0 & 42.0 & 83.5 & 97. & 67.5 & 11.9 & 2,525 \\
\hline$\$ 3532$ & A & 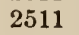 & 250 & $\mathrm{D}$ & 73.3 & 40.0 & 41.0 & 77.5 & 87.8 & 61.4 & 10.2 & 2,360 \\
\hline$\$ 3560$ & St G & 507 & 2506 & Aug. 20,1918 & 74.7 & 42.3 & 41.1 & 77.8 & 89.4 & 63.6 & 11.2 & 2,170 \\
\hline @ 3652 & A & 2510 & 2506 & Nov. 2,1918 & & 37.8 & 37.9 & 77.2 & 89.2 & 63.2 & 10.7 & \\
\hline \& 3654 & St G & 2510 & 2506 & Do. & 72.7 & 38.4 & 40.1 & 76.7 & 89.1 & 62.5 & 10.3 & 2,050 \\
\hline @ 3655 & St G & 10 & 2506 & $\mathrm{D}$ & & & & 79.9 & 92.1 & & 10.9 & \\
\hline & A & 2436 & 2434 & D & 79.0 & 40.8 & 40.4 & 87.6 & 103.0 & 70.0 & 11.3 & , 380 \\
\hline † 3658 & A & 436 & 2434 & $\mathrm{D}$ & 72.7 & 41.4 & 42.0 & 80.5 & 93. & 63.0 & 10.1 & 2,260 \\
\hline @ 3659 & St $G$ & 243 & 243 & D & 75.6 & 42.4 & 41.8 & 85.6 & 100. & 67.1 & 10. & 2,545 \\
\hline † 3661 & A An & 2432 & 2434 & $\mathrm{D}$ & 78.8 & 40.6 & 40.4 & 88.3 & 102. & 69.4 & 11.4 & 2,500 \\
\hline & A & 2432 & 2434 & Do & 79.3 & 42.3 & 41.4 & 87.5 & $102.8-2-2$ & 68.7 & 10. & .630 \\
\hline$\$ 3826$ & Blue & 2474 & 2473 & Feb. 25,1919 & 74.3 & 41.5 & 39.9 & 82.2 & 96. & 65.9 & 11.5 & 2,190 \\
\hline \$ 3836 & G & 2511 & 2866 & Do. & 75.0 & 39.3 & 41.0 & 77.3 & 91.8 & 64.1 & 10.9 & 2,125 \\
\hline
\end{tabular}


TABLE 33.-Descriptive list of rabbits studied-Continued.

VIII. $F_{2}$, Polish $\times$ Flemish-Continued.

\begin{tabular}{|c|c|c|c|c|c|c|c|c|c|c|c|c|}
\hline $\begin{array}{c}\text { Designa- } \\
\text { tion. }\end{array}$ & Color. & 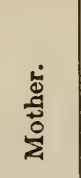 & 芯 & Born. & 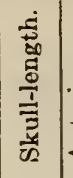 & 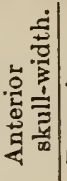 & 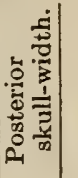 & $\underset{\mathrm{g}}{\stackrel{\underline{g}}{0}}$ & $\frac{\pi}{\tilde{E}}$ & 总 & 宛 & $\begin{array}{l}\frac{0}{0} \\
\frac{\pi}{0}\end{array}$ \\
\hline & A & 2451 & 2866 & Feb. 27, 1919 & $67.7 \mid$ & 39.3 & 40.0 & 72.5 & 85.1 & 58.7 & 10.21 & 1,710 \\
\hline & C & & & Do. & 76.8 & 40.4 & 40.1 & 81.0 & 92.3 & 65.9 & & 2,315 \\
\hline & D & 76 & 2866 & eb. 25,1 & 74.6 & 41.0 & 41.3 & 80.0 & 90.9 & $62.6 \mid 1$ & & 2,255 \\
\hline & Blue & 2576 & 2866 & Do. & $69.8 \mid$ & 40.6 & 39.5 & 76.4 & 89.1 & 61.4 & 10.31 & 1,770 \\
\hline & St G & 10 & 2866 & Do & 73.8 & 40.4 & 40.5 & 82.4 & 93.5 & 66.3 & & 2,13 \\
\hline & B & 09 & 2866 & $\mathrm{D}$ & 68.5 & 37.2 & 40.0 & 73.1 & 82.5 & 57.5 & 10.01 & 1,780 \\
\hline & B & 09 & 2866 & Do & 68.7 & 38.3 & 39.7 & 75.8 & 88.3 & $60.6 \mid$ & & $1,7 €$ \\
\hline & Blu G An & 2436 & 2434 & Do. & 70.1 & $|39.6|$ & 40.3 & 82.0 & 95.2 & 65.0 & $10.5 \mid 1$ & 1,920 \\
\hline क & 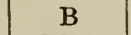 & 2511 & 2866 & May 5, 1919 & 70.0 & $|38.7|$ & 39.8 & 80.7 & 93.1 & $64.5 \mid$ & 10.6 & \\
\hline & Blue & 2431 & 2433 & Mar. 15, 1919 & 74.3 & & 39.8 & 82.7 & 95.9 & 63.9 & 10.92 & 2,370 \\
\hline & Blu & 2436 & $24 i$ & Apr. 16, & 74.0 & 42.1 & 41.8 & 86.3 & 98.0 & 65.3 & 11.0 & 2,00 \\
\hline & Blue G & 2436 & 2434 & Do. & 74.6 & 42.2 & 41.8 & 78.7 & 93.2 & 63.3 & 10.2 & $|2,200|$ \\
\hline$\sigma^{2}$ & B & 2509 & 2506 & Apr. 17,1918 & & & & & & & 11.5 & \\
\hline & A & 2437 & 2434 & Do. & 76.5 & 42.1 & 40.9 & 86.31 & 100.4 & 66.9 & 11.5 & $2,225 \mid$ \\
\hline & $\mathbf{Y}$ & 2437 & 2434 & D & 80.2 & 40.6 & 41.6 & 85.1 & 99.1 & 66.0 & 11.0 & 2,380 \\
\hline & St G & 2437 & 2434 & D & $70.4 \mid$ & 41.4 & 40.9 & 77.9 & 92.2 & 62.8 & $\left.9.8\right|_{2} ^{2}-2$ & $|2,025|$ \\
\hline & A & 2430 & 2434 & D & 68.9 & 39.3 & 40.4 & 80.5 & 91.0 & 61.4 & 10.6 & \\
\hline & $\mathbf{Y}$ & 2 & 2434 & & 68.5 & & & 81.5 & 95.7 & 62.8 & 10.2 & \\
\hline & B & 2432 & 2434 & Apr. 18,1918 & 77.0 & 42.0 & 42.5 & 83.5 & 97.4 & 67.4 & 10.8 & 2,315 \\
\hline & A & 2432 & 2434 & Do & 69.3 & 39.3 & $\mid 40.4$ & & 88.0 & 60. & 9.5 & 1,91 \\
\hline & Blue $\mathrm{G}$ & 2511 & 2506 & Apr. 19,1918 & 74.4 & 41.4 & 40.6 & 80.8 & 96.8 & 65.0 & 11.1 & 2,050 \\
\hline & & 2511 & 2506 & Do. & 76.6 & 41.6 & 41.5 & 83.3 & 99.4 & 66.0 & 11.9 & 2,45 \\
\hline & $\mathrm{G}$ & 576 & 2506 & D & & & & & & & 11.7 & \\
\hline & B & 576 & 2506 & & $|73.7|$ & 41.6 & 41.0 & 78.8 & 91.3 & 62.7 & 10.3 & 2,03 \\
\hline & sit & 0 & 25 & & 72.8 & 41.4 & 39.8 & 75.1 & 87.7 & 61.5 & $\mid 10.5$ & 1,9 \\
\hline & $\mathrm{B}$ & 0 & 2506 & $\mathrm{D}$ & 71.8 & 41.4 & 40.0 & 76.3 & 90.1 & 61.6 & 10.0 & 1,89 \\
\hline & F & 4 & 2473 & May 6,1918 & 71.1 & 40.4 & 439.0 & 76.9 & 90.9 & 61.9 & 10.4 & 1,7 \\
\hline & D & 74 & 2473 & Do & 70.1 & 39.9 & 40.0 & 76.1 & 89.3 & 60.8 & 10.5 & 1,76 \\
\hline & $\approx$ & 4 & 24 & & $67.0 \mid$ & 40.3 & 38.9 & 75.0 & 86.9 & 95.7 & 70.2 & 1,5 \\
\hline & St G & 2430 & 2434 & une 14,1 & 72.8 & 40.0 & 40.1 & 82.5 & 95.7 & 764.0 & 10.2 & 1,8 \\
\hline & $\mathrm{B}$ & 2 & 24 & & 70.9 & 40.1 & 139.9 & 78.5 & 88.9 & 961.1 & & 2,0 \\
\hline & $\mathrm{Bl}$ & 24 & 24 & & 75.0 & 41.8 & $8 \mid 40.6$ & 83.7 & 98.4 & 465.6 & 6 & 2,17 \\
\hline & $c$ & & & & 74.2 & 42.5 & 542.0 & 80.4 & 94.2 & 263.6 & .9 & 2,25 \\
\hline & I & 25 & 25 & & 74.9 & 42.7 & 742.6 & 78.8 & 90.3 & 362.7 & 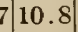 & 2,0 \\
\hline & A & & & & 73.2 & 41.1 & 140.5 & 78.4 & 89.9 & 962.1 & .2 & 1, \\
\hline & B An & 24 & 24 & & 78.6 & 41.3 & 342.0 & $84.7 \mid 1 \quad-1$ & 100.6 & $6 \quad 66.7$ & $7 \mid 11.3$ & 2,16 \\
\hline & $C$ & & & June 1 & 72.0 & 42.2 & 242.7 & 77.3 & 87.4 & 461.5 & $\begin{array}{ll}5 & 10.2 \\
\end{array}$ & 1,8 \\
\hline & St G & 2 & 25 & & 77.0 & 43.5 & 542.4 & 81.4 & 94.0 & 05.9 & $9 \mid 11.7$ & 2,20 \\
\hline & 12 & & & ne 1 & 76.9 & 41.5 & 542.5 & 88.3 & 104.6 & .3 & .5 & 52,4 \\
\hline & A An & & 24 & & 72.6 & \begin{tabular}{|l|l}
51.8 & 41.8
\end{tabular} & 840.6 & 80.9 & 95.3 & 365.0 & 0.10 .1 & 1,7 \\
\hline & $A$ & & & & 72.5 & 51.9 & 941.7 & 82.4 & 98.6 & 664.8 & 810.2 & \\
\hline & & 2 & 24 & & 75.7 & 41.6 & 641.3 & 81.0 & 93.4 & 464.4 & $4 \mid 10.7$. & 2 \\
\hline & & & & he 1 & 79.4 & & & 85.2 & 97.2 & 269.1 & 112.0 & 2 \\
\hline & & 2 & 24 & ly 1 & 73.4 & 41.0 & 040.9 & 83.1 & 99.6 & 63.1 & $\begin{array}{lll}1 & 11.6\end{array}$ & 62 \\
\hline & G & & & & 75.9 & 42.8 & 843.0 & 84.9 & 100.0 & 067.7 & 7 & 72,39 \\
\hline & $\mathbf{A}$ & 25 & 25 & July 23, 1918 & 70.8 & 80.6 & 640.4 & 82.8 & $95 . c$ & 065.9 & \begin{tabular}{l|l}
9 & 10.4
\end{tabular} & \\
\hline & St $\mathrm{G}$ & & & D & 72.9 & 42.5 & 543.0 & 79.8 & 93.3 & 364.4 & 411.2 & $\begin{array}{l}2,12 \\
2,12\end{array}$ \\
\hline & 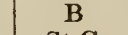 & & 25 & $\mathrm{D}$ & 69.8 & 39.6 & 641.3 & 79.6 & 92.6 & 662.7 & $\begin{array}{ll}7 & 10.8\end{array}$ & \\
\hline & St $\mathbf{G}$ & & 25 & Do & 72.1 & 40.7 & 741.2 & 77.5 & 86.3 & 362.5 & 510.5 & 51, \\
\hline & & 247 & 247 & July 4,1918 & 69.4 & 39.6 & $6|39.8|$ & 76.8 & 89.8 & 861.1 & 10.8 & 81,7 \\
\hline & St $\mathrm{C}$ & 245 & 25 & Do & 77.2 & 242.8 & $8 \mid 42.1$ & 86.3 & 97.7 & $7 \mid 70.7$ & \begin{tabular}{l|l}
7 & 12.2
\end{tabular} & \\
\hline & G & $24 !$ & 25 & D & 74.0 & 42.2 & 241.8 & 80.3 & 92.4 & 465.3 & \begin{tabular}{l|l}
3 & 10.7
\end{tabular} & \\
\hline & G & 257 & 25 & D & & 641.9 & $9 \mid 41.5$ & 79.5 & 92. & \begin{tabular}{l|l}
6 & 61.0
\end{tabular} & \begin{tabular}{l|l}
0 & 10.8
\end{tabular} & 82, \\
\hline & $B$ & 25 & 25 & D & 74.1 & \begin{tabular}{l|l}
1 & 42.7
\end{tabular} & $7|41.7|$ & 78.0 & 90. & $\begin{array}{ll}561.7\end{array}$ & \begin{tabular}{l|l}
7 & 10.3
\end{tabular} & 31,9 \\
\hline & St & 25 & 25 & & 71.8 & 840.9 & 940.8 & 80.5 & 92. & 864.6 & $\begin{array}{ll}6 & 10.4\end{array}$ & \\
\hline & St G & 251 & 25 & D & 73.1 & 40.6 & $6 \mid 41.1$ & 82.0 & 95. & $\begin{array}{ll}3 & 66.2\end{array}$ & \begin{tabular}{l|l}
2 & 11.2
\end{tabular} & 22,3 \\
\hline o'3534 & B & 2511 & 2506 & Do. & 71.6 & 840.6 & $\begin{array}{lll}6 & 41.2\end{array}$ & 80.7 & 96. & 367.1 & 110.7 & $\begin{array}{l}7 \\
2,19\end{array}$ \\
\hline
\end{tabular}


Table 33.-Descriptive list of rabbits studied-Continued.

VIII. $F_{2}$, PoLrsh $\times$ FLemish-Continued.

\begin{tabular}{|c|c|c|c|c|c|c|c|c|c|c|c|c|}
\hline $\begin{array}{c}\text { Designa- } \\
\text { tion. }\end{array}$ & Color. & 密 & 离 & Born. & 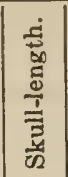 & 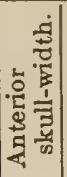 & 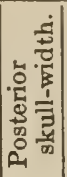 & 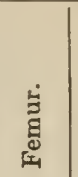 & 苛 & 竞 & 菢 & 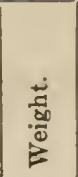 \\
\hline$\sigma^{\top} 3603$ & A An & 2430 & 2434 & Aug. 1,1918 & 75.0 & 42.7 & 41.6 & 88.3 & 101.9 & 69.0 & 11.7 & 2,335 \\
\hline क 3604 & $\mathrm{~B}$ & 2430 & 2434 & Do. & 76.3 & 42.2 & 41.7 & 87.5 & 100.5 & 69.1 & 11.4 & 2,485 \\
\hline $0^{7} 3656$ & A An & 2436 & 2434 & Nov. 2,1918 & 74.6 & 41.2 & 41.4 & 83.8 & 96.2 & 64.6 & 10.2 & 2,110 \\
\hline$\sigma^{2}$ & St G & 2436 & 2434 & Do. & 71.1 & $39.6 \mid$ & 40.7 & 80.9 & 93.5 & 64.2 & 9.6 & 2,150 \\
\hline$\sigma^{2}$ & A & 2432 & 2434 & Do. & 79.9 & 41.5 & 42.4 & 87.3 & 101.2 & 69.7 & 12.1 & 2,450 \\
\hline$\sigma^{2}$ & Blue & 2432 & 2434 & Do. & 71.7 & 40.7 & 41.3 & 82.2 & 96.8 & 65.5 & 9.9 & 1,900 \\
\hline $0^{2}$ & B An & 2432 & 2434 & Do. & 77.8 & 42.2 & 41.9 & 86.9 & 102. & 68.4 & 10.9 & 2,450 \\
\hline & St $\mathbf{G}$ & 2511 & 2866 & Feb. 25,19 & 67.9 & 39.3 & 40.8 & 79.5 & 93.5 & 62.7 & 10.3 & 1,920 \\
\hline $0^{7}$ & G & 2451 & 2866 & Feb. 27,1 & 75.2 & 41.0 & 41.8 & 75.7 & 88.2 & 58.8 & 10.8 & 1,645 \\
\hline & A & 2576 & 286 & Feb. 25,1 & 68.9 & 40.0 & 41.0 & 74.9 & 88.4 & 59.6 & 9.8 & 1,730 \\
\hline $0^{2}$ & B & 2576 & 2866 & Do. & 70.7 & 41.5 & 40.1 & 78.0 & 91.1 & 61.8 & 10.4 & 2,025 \\
\hline & Blue $G$ & 2576 & 28 & $\mathrm{D}$ & & 41.4 & 41.2 & 78.7 & 90.6 & 61.2 & 10.7 & 1,870 \\
\hline$\sigma^{7} 3859$ & B & 2510 & 2866 & Do. & & 39.9 & 41.0 & 79.0 & 90.7 & 60.5 & 10.3 & 1,850 \\
\hline & A & 24 & 2434 & Feb. 24, & 72.0 & 41.5 & 41.8 & 81.9 & 98.1 & 63.5 & 10.3 & 2,000 \\
\hline $0^{7} 3882$ & G & 2509 & 2866 & Feb. 25, & 69.3 & 40.8 & 41.5 & 78.9 & 90.9 & 64.3 & 11.2 & 1,970 \\
\hline$\sigma^{7} 3889$ & Dil & 2436 & 2434 & Feb. 24,1 & 73.5 & 42.5 & 42.8 & 86.0 & 99.5 & 56.4 & 10.7 & 2,100 \\
\hline & St G & 2511 & 2866 & May 5,1919 & & 39.6 & 40.4 & 78.1 & 93.6 & 63.4 & 10.8 & 2,010 \\
\hline & A & 2511 & 2866 & Do. & 67.6 & 38.2 & 37.8 & $\mid 71.3$ & 84.9 & 56.3 & 3.3 & 1.675 \\
\hline & St G & 2436 & 2433 & Do. & 70.3 & 41.7 & 40.8 & 80.3 & 95.4 & 462.8 & 3.8 & 1,800 \\
\hline $0^{7} 4068$ & Y An & 2432 & 2434 & Mar. 3, 1919 & & 40.8 & 40.9 & 85.2 & 101.2 & 66.3 & 311.5 & 1.920 \\
\hline
\end{tabular}

IX. $F_{2}$, Himalayan $\times$ Flemish.

\begin{tabular}{|c|c|c|c|c|c|c|c|c|c|c|c|c|}
\hline $\begin{array}{l}\text { Designa- } \\
\text { tion. }\end{array}$ & Color. & 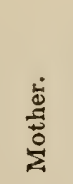 & 志 & Born. & 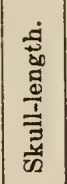 & 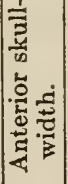 & 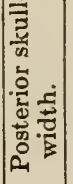 & 气 & हैं & 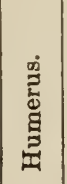 & 离 & 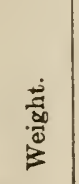 \\
\hline १ 2983 & $\mathrm{H}$ & 2646 & 2647 & Apr. 18,1918 & 74.6 & 41.8 & 41.5 & 81.9 & 93.9 & 64.4 & 10.8 & 2,220 \\
\hline$\$ 298$ & G & 2646 & 2647 & Do. & 78.8 & 38.9 & 40.4 & 83.7 & 96.4 & 65.3 & 12.3 & $2,125 \mid$ \\
\hline \& 2987 & B & 2646 & 2647 & Do. & 80.8 & 40.7 & 41.0 & 88.3 & 101.4 & 67.6 & 11.9 & $2,535 \mid$ \\
\hline \& 2988 & B & 2646 & 2647 & Do. & 76.5 & 41.8 & 41.8 & 82.4 & 94.7 & 64.0 & 11.3 & 2,400 \\
\hline † 3024 & B & 2517 & 2522 & Apr. $20,191 \mathrm{~s}$ & 75.0 & 41.8 & 40.4 & 84.7 & 98.2 & 68.4 & 11.6 & 2,675 \\
\hline † 3025 & G & 2517 & 2522 & Do. & 76.9 & 41.8 & 42.0 & 82.9 & 96.3 & 66.1 & 11.7 & $2,900]$ \\
\hline ㅇ 3026 & St G & 2517 & 2522 & Do. & 73.0 & 41.3 & 42.8 & 84.4 & $|96.7|$ & 67.5 & 12.2 & 2,590 \\
\hline ㅇ 3054 & G & 2521 & 2522 & Арг. 22,1918 & 78.5 & 40.1 & 39.7 & 84.4 & 97.9 & 66.6 & 11.3 & 2.160 \\
\hline ○ 3149 & G & 2517 & 2522 & June 14,1918 & 75.9 & 41.5 & 40.7 & $\$ 2.9$ & 94.0 & 66.8 & 12.1 & 2,680 \\
\hline † 3150 & St G & 2517 & 2522 & Do. & 76.0 & 40.8 & 41.7 & 84.4 & \begin{tabular}{|l|}
94.9 \\
\end{tabular} & 68.0 & 12.0 & 2,480 \\
\hline ๆ 3151 & St $\mathbf{G}$ & 2517 & 2522 & Do. & 76.1 & 42.6 & 41.8 & 87.3 & 98.9 & 69.7 & 12.7 & 2,380 \\
\hline † 3153 & $\mathrm{H}$ & 2521 & 2522 & Do. & 77.1 & 41.4 & 40.5 & 88.8 & 101.3 & 71.4 & 12.1 & 2,705 \\
\hline ○ 3157 & B & 2521 & 2522 & Do. & 74.4 & 41.5 & 41.5 & 83.9 & 97.3 & 67.4 & 11. & $2,290 \mid$ \\
\hline \$3202 & B & 2646 & 2647 & Do. & 78.3 & 41.9 & 42.7 & 81.9 & 93.2 & 64.0 & 11.1 & 2,440 \\
\hline † 3228 & St $G$ & 2645 & 2647 & Do. & 77.5 & 44.7 & 43.4 & 85.4 & 97.0 & 69.4 & 12.0 & $2,880 \mid$ \\
\hline \& 3373 & G & 2519 & 2522 & July 20,1918 & 75.4 & 39.6 & 39.6 & 81.9 & 95.7 & 65.4 & 11.7 & 2,400 \\
\hline$\$ 3375$ & G & 2519 & 2522 & Do. & 77.2 & 40.2 & 40.8 & 82.6 & 93.0 & 65.4 & 11.3 & $2,070 \mid$ \\
\hline @ 3385 & U & 2642 & 2647 & June 27,1918 & 77.3 & 40.5 & 40.5 & 82.4 & 95.9 & 65.5 & 11.0 & 2,850 \\
\hline 우 3387 & St $\mathbf{G}$ & 2642 & 2647 & Do. & & & & & & & 10.8 & \\
\hline \$3389 & St G & 2642 & 2647 & Do. & 74.4 & 40.9 & 41.3 & 81.4 & 95.0 & 66.3 & 11.3 & 2,520 \\
\hline 우 3439 & $\mathrm{H}$ & 2517 & 2522 & Aug. 16,1918 & 76.8 & 42.1 & 42.2 & 87.3 & 99.6 & 69.6 & 11.1 & 2,750 \\
\hline$\$ 3441$ & St G & 2517 & 2522 & Do. & 69.8 & 38.9 & 38.4 & 79.2 & 90.9 & 63.1 & 10.9 & 2,260 \\
\hline † 3442 & St G & 2517 & 2522 & Do. & 75.9 & 41.9 & 40.4 & 87.9 & 100.5 & 71.0 & 11.8 & 2,900 \\
\hline
\end{tabular}


TABLE 33.-Descriptive list of rabbits studied-Continued.

IX. $F_{2}$, Himajanyan $\times$ Flemish-Continued.

\begin{tabular}{|c|c|c|c|c|c|c|c|c|c|c|c|c|}
\hline $\begin{array}{l}\text { Designa- } \\
\text { tion. }\end{array}$ & Color. & 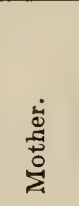 & 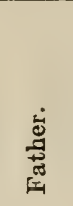 & Born. & 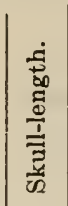 & 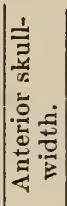 & 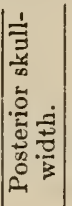 & 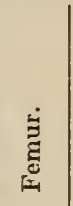 & 葛 & 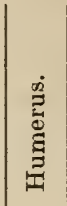 & 它 & 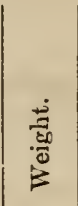 \\
\hline ㅇ 3443 & B & 2517 & 2522 & Aug. 16, 1918 & 79.1 & 42.3 & 42.9 & 87.5 & 101.0 & 69.8 & 12.6 & 2,530 \\
\hline & St $G$ & 2517 & 2522 & Do. & 73.3 & 40.9 & 41.9 & 82.7 & 93.8 & 67.6 & 11.12 & 2,410 \\
\hline 운 & G & 2645 & 2647 & Do. & 76.1 & 38.7 & 40.7 & 84.0 & 95.6 & 67.3 & $11.0 \mid 2$ & 2,440 \\
\hline$\$ 35$ & G & 2521 & 2522 & Do. & 78.0 & 43.3 & 41.7 & 86.5 & 99.1 & 69.6 & 11.52 & 2,560 \\
\hline ㅇ 35 & G & 2521 & 2522 & Do. & 74.0 & 40.1 & 40.8 & 81.5 & 92.5 & 65.0 & $11.02_{2}$ & 2,275 \\
\hline ㅇ 35 & G & 2830 & 2647 & Aug. 21,1918 & 83.8 & 45.3 & 45.2 & 89.0 & 100.5 & 69.2 & $11.82_{2}$ & 2,710 \\
\hline$\subsetneq 35$ & G & 2646 & 2647 & Sept. 1,1918 & 77.8 & 42.8 & 42.7 & 87.3 & 98.6 & 67.3 & 12.8 & 2,750 \\
\hline @ 3 & $\mathrm{H}$ & 2646 & 2647 & Do. & 81.3 & 43.5 & 43.8 & 89.5 & 100.0 & 69.7 & 12.7 & 2,990 \\
\hline$\$ 36$ & $\mathrm{G}$ & 2646 & 2647 & Do. & 79.8 & 42.7 & 42.9 & 88.7 & 101.7 & 70.8 & 11.8 & 2,620 \\
\hline ๑: & $\mathrm{H}$ & 19 & 2522 & Nov. 2,1918 & 74.2 & 41.0 & 42.4 & 83.5 & 95.5 & 64.6 & 11.6 & 2,500 \\
\hline$\sigma^{2} 30$ & $\mathrm{H}$ & 17 & 2522 & Apr. 20,1918 & & & & & & & 12.1 & \\
\hline$\sigma^{7}$ & G & 21 & 2522 & Apr. 22,1 & 76.8 & 41.2 & 41.4 & 86.1 & 99.5 & & 12.2 & \\
\hline$\sigma^{\pi}$ & G & 21 & 2522 & Do. & 79.3 & 41.7 & 41.9 & 85.1 & 97.4 & 66.3 & 11.3 & \\
\hline $0^{7}$ & $\mathrm{H}$ & 17 & 2522 & June 14,1918 & 74.8 & 41.0 & 41.6 & 84.6 & 96.2 & 67.3 & 11.2 & 2,185 \\
\hline $0^{3}:$ & St $G$ & 17 & 2522 & Do. & 74.8 & 42.2 & 42.5 & 83.4 & 95.4 & 67.5 & 11.9 & 2,170 \\
\hline $0^{7}$ & $\mathrm{St}$ & 17 & 2522 & Do. & 72.5 & 41.9 & 42.4 & 82.5 & 96.4 & 67.7 & 11.3 & 2,190 \\
\hline & G & 21 & 522 & Do & 73.8 & 40.9 & 41.2 & 83.2 & 96.5 & 67.1 & 10.8 & 2,300 \\
\hline $0^{7}$ & B & 21 & 2522 & Do. & 74.3 & 41.3 & 41.2 & 81.2 & 94.2 & 64.9 & 11.1 & 2,300 \\
\hline$\sigma^{2}$ & $\mathrm{G}$ & 46 & 8 & Do & 76.6 & 41.8 & 42.5 & 83.9 & 97.4 & 66.2 & 12.0 & 2,455 \\
\hline & G & 46 & 2647 & Do & 73.6 & 42.8 & 43.1 & 78.9 & 93.0 & 63.1 & 10.7 & 2,450 \\
\hline & G & 46 & 7 & Do. & 73.1 & & & 81.5 & 96.6 & 64.6 & 11.1 & \\
\hline$\sigma^{73}$ & St $\mathrm{G}$ & 345 & 2647 & Do & 76.9 & 43.4 & 44.0 & 83.7 & 96.0 & 66.4 & 11.5 & 2,480 \\
\hline $0^{2} 3$ & $\mathrm{H}$ & 19 & 2 & July 20,19 & & & & 84.9 & 98.3 & 67.7 & 11.6 & 2,350 \\
\hline $0^{2}$ & s & 12 & 2647 & June 27,1 & & & & & & & $\mid 10.8\}$ & \\
\hline & & & 7 & Do. & & & & & & & 10.8 & \\
\hline 0 & St $\mathrm{G}$ & 17 & 2522 & Aug. 16, 1918 & 75.7 & 41.9 & 42.6 & 87.2 & 100.0 & 70.2 & 11.3 & 2,470 \\
\hline & $\mathrm{P}$ & & 2522 & Do. & 78.0 & 41.8 & 41.5 & 90.3 & 10 & 71.0 & 12.1 & 2,440 \\
\hline & G & 831 & 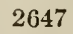 & & 76.2 & 43.4 & 43.0 & 86.7 & 98.1 & 70.7 & 11.3 & 2,555 \\
\hline & G & & & & 77.0 & 42.3 & 42.7 & 86.9 & 99.9 & 70.8 & 10.9 & 2,690 \\
\hline & H & 2645 & 26 & & 77.9 & 42.1 & 42.5 & 82.9 & 93.2 & 64.6 & 11.8 & 2,460 \\
\hline & $\mathbf{H}$ & & & & 77.8 & 43.2 & 44.0 & 83.4 & 95.8 & 66.4 & 11.0 & 2,490 \\
\hline & G & 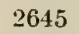 & & & 76.2 & 40.5 & 42.4 & 80.3 & 91.5 & 562.7 & 11.2 & 2,430 \\
\hline & $\mathrm{G}$ & & & & 77.6 & 40.6 & & 85.4 & 95.5 & 68.2 & 12.0 & 2,390 \\
\hline & $\mathrm{G}$ & & & & 81.2 & 44.2 & 43.1 & 88.8 & 100.7 & 769.8 & 12.8 & 2,740 \\
\hline & St G & & & & 70.8 & 40.4 & 41.3 & 80.8 & 90 & 64.9 & 11.2 & 2,190 \\
\hline & 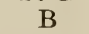 & 521 & & & 70.4 & 40.9 & 40.0 & 81.9 & 95.6 & 65.0 & 10.6 & 2,070 \\
\hline & $\mathrm{G}$ & & & & 76.1 & 40.4 & & 86.0 & 99.8 & 867.2 & 11.2 & 2,170 \\
\hline & $\mathrm{G}$ & 252 & 2 & & 76.3 & 41.3 & 41.6 & 86.1 & 98.9 & 67.8 & 11.4 & 2,305 \\
\hline & $\mathrm{G}$ & & 2647 & Aug. 21, 1918 & 80.3 & 42.3 & 42.7 & 85.2 & 98.1 & 67.2 & 11.1 & 2,420 \\
\hline & $\mathrm{G}$ & & 26 & & & & & & & 64.0 & 10.6 & \\
\hline & $\mathrm{G}$ & & 2647 & Sept. 1,1 & 80.3 & 348 & .6 & 88.6 & 10 & 68.1 & &, 525 \\
\hline & G & & 2647 & $\mathrm{D}$ & 79.9 & 42.0 & 43.2 & 84.6 & 98 & 67. & 12.0 & 2,500 \\
\hline & G & & 26 & D & 80.3 & 41.9 & 44.7 & 89.5 & 10 & 71 & 12.0 & 2,350 \\
\hline & G & 26 & 2647 & $\mathrm{D}$ & 83.7 & 44.0 & 45.0 & 89.7 & 10 & 71 & 12.4 & 2,870 \\
\hline & $\mathrm{H}$ & 251 & 2522 & Nov. 2,1918 & 73.6 & 43.4 & 43.0 & 88.0 & 99.8 & 370.3 & $\mid 12.3$ & 2,595 \\
\hline & $\mathrm{H}$ & 2519 & 2522 & Do. & 77.2 & 243.9 & 44.4 & 89.4 & 103.2 & 69.8 & $\mid 12.9$ & 2,640 \\
\hline$\sigma^{2} 3650$ & $\mathrm{G}$ & 2519 & 2522 & Do. & 71.9 & 40.7 & 40.9 & 82.7 & 99.1 & 166.2 & 11.6 & 2,070 \\
\hline
\end{tabular}




\section{PART II.}

\section{ON A NON-TRANSMISSIBLE TRI-COLOR VARIATION IN RATS.}

In the course of studies of linkage in rats, I have observed the production of a tri-color individual, gray, yellow, and white, similar to the tri-color varieties of guinea-pig, and I had hoped to establish from it a new color variety of rat, but thus far no success has attended my efforts. The case, in its bearings on the nature and origin of variations, is not without interest, and so will be described briefly.

The two genes whose linkage relations were being investigated when the tri-color individual made its appearance have been designated $c$ and $p$. Both are recessive in crosses and thus become visible as somatic characters only when present in the homozygous state, $c c$ or $p p$ respectively. An individual of the formula $c c$ is an albino; an individual of the formula $p p$ is pink-eyed and yellow-coated.

When an ordinary albino is crossed with a pink-eyed yellow individual, young are produced which are neither albinos nor pink-eyed yellow, since neither $c$ nor $p$ will be homozygous in the cross-bred individuals, which are in fact gray in color like wild rats, or else gray-hooded, if the gene for hooded pattern is present in homozygous condition. By means of such crosses between albino and pink-eyed yellow rats, gray and gray-hooded young were being produced when the tri-color individual made its appearance. It is a gray-hooded individual, like its brothers and sisters, except that the areas normally gray are liberally mottled with yellow. The mottling extends practically throughout the colored portions of the coat from nose to tail tip. The yellow areas vary in size from those which contain merely a few yellow hairs to those of a square inch in extent. The least yellow is found on the right shoulder, which is almost like normal gray in appearance. The most yellow is found in the middle of the back, to the left of the median line, where a large spot of clear yellow occurs in the wide back-stripe of the hooded pattern, which would correspond roughly with grade $+2 \frac{1}{2}$ of the grading scale used in our studies of hooded rats.

The tri-color individual is, fortunately for the purposes of genetic study, a male. He has been mated with albinos, with pink-eyed yellows, and with gray $F_{1}$ cross-breds between the albino and the pink-eyed yellow races, and later with his own daughters of the colors white, pink-eyed yellow, and gray. Hundreds of young have been produced by these matings, for the animal is a remarkably large and vigorous one and his mates have proved very prolific, but 
not one of the young was mottled like the sire. This occasioned no surprise when the mates were not related to the tri-color male or were not his direct descendants, for it was conjectured that he might be a mutant due to a new recessive gene, which accordingly would only become visible when in a homozygous state. But if he himself represented such a homozygous recessive combination, all his gametes should transmit the mottled condition, and all his daughters consequently should be heterozygous for the mottled condition, and in matings with their sire should produce 50 per cent of mottled individuals. The fact that they do not produce mottled individuals shows this hypothesis to be untenable.

The tri-color male, in fact, breeds like his gray-hooded brothers and sisters, producing gametes which are commonly either $c$ or $p$, but which in no case transmit a mosaic relationship. From his ancestry and from the results of his matings, we know him to be a double heterozygote, $C c P p$. The Mendelian expectation is that he will form four kinds of gametes, $c P, C p, C P$, and $c p$, but since there exists linkage (in this case repulsion) between $c$ and $p$, the first two classes of gametes will be commoner than the other two. His breeding behavior accords with these expectations. In most of his gametes he transmits either albinism or pink-eyed yellow. In an occasional gamete he probably transmits both, a matter which has not been tested, as it would require special matings. It is certain that in an occasional gamete he transmits neither $c$ nor $p$, a condition expressed in the formula $C P$, which like $c p$ would represent a crossover. His gametes, accordingly, appear to be such as are normally produced by $F_{1}$ doubly heterozygous individuals like his gray and gray-hooded brothers and sisters.

How, then, can we account for the production of yellow areas in the gray coat? By an explanation similar to that which Morgan and Bridges (19191) have given to account for the production of gynandromorphs in Drosophila. We may suppose that at an early cleavage (perhaps the first) of the fertilized egg from which this rat developed, one of the pair of chromosomes, in which the genes $c$ and $p$ are borne, failed to divide as normally, or that for some other reason it failed to pass into one of the cell-products. Further consideration shows that it must have been the maternal rather than the paternal chromosome of this pair which was lost. For the mother was an albino and must have contributed $c P$, but the father was a pink-eyed yellow, $C p$, and his contribution by itself would produce yellow fur, whereas with the mother's contribution it would produce gray. We may suppose, accordingly, that a blastomere containing only the paternal contribution produced that part of the 
skin which is yellow, and that a blastomere or blastomeres containing as normally both maternal and paternal members of this chromosome pair produced the gray part of the coat.

But how about the germ-cells of this individual? Does the mixed condition seen in the coat obtain also among the germ-cells? Very likely it does. But if so, no tri-color progeny need be expected in consequence. For those germ-cells which correspond in composition with the gray parts of the coat would produce gametes like those of any other $F_{1}$ individual, which for the most part would transmit either albinism or pink-eyed yellow, with an occasional gamete transmitting gray and an occasional gamete transmitting both albinism and pink-eyed yellow. But the germ-cells corresponding to the yellow parts of the coat would transmit either pink-eyed yellow or nothing (so far as the chromosome under discussion is concerned). It is an open question whether this last type of gamete (lacking the entire chromosome) would be viable, and if it were, its existence would be difficult to detect, since it would behave like the double recessive type of gamete, $c p$, in its effects on coat color.

How, then, could a genuine genetically transmissible type of mottled rat arise? Only, I suppose, by a change in the genetic locus at $P, p$, so that it became, instead of $P$ alone or $p$ alone, a mosaic $P p$ transmissible as a unit and capable of functioning as the allelomorph either of $P$ or of $p$. Such apparently is the case in the guinea-pig, where Ibsen has shown the mottled condition to be the allelomorph of both simple black and simple yellow. Such apparently is also the condition in the mottled variety of rabbit called "Japanese," which I have recently studied in a series of crosses, and such would appear to be the case in maize with striped pericarp, which has been extensiveiy studied by Emerson and his associates. They find that the mosaic factor frequently becomes simple by mutation either to all red or to all white, and that mutation occurs oftenest to that component of the mosaic which is most extensive in the parent. This result is easily understood if we suppose that the mosaic "gene" divides in such a way as to include more of one of its components than of the other in a cell product, or so as to contain only the major component in a cell product. That cell would then develop into a self-colored individual. I think that this idea of a mosaic gene will explain the high degree of variability which is found not only in striped maize, but also in spotted mammals, whether spotted with yellow or with white. Hooded rats and Dutch rabbits are examples of spotted mammals which I have studied extensively and have found to be amenable to selection like the striped pericarp of maize studied by Emerson and by Hays, probably for the same reason, viz, because a mosaic gene varies (or, if you prefer, "mutates") in the proportions of its constituents. 
In $1912^{1}$ I described a peculiar guinea-pig, which, in the light of the present case, I am inclined to explain in the same way as the tri-color rat, as a non-transmissible though not of necessity a purely somatic mutation. At that time I characterized the guinea-pig in question as a "pink-eyed individual with a colored coat," but this is not a very good description for it. The description fits better a genuine genetically transmissible variety that was then unknown to us, but which curiously enough was soon to appear in our breedingpens from stock that had recently been obtained in Peru. The individual, whose peculiarities were not transmitted to its offspring, was by pedigree a heterozygote between albinism and pale black. Such a heterozygote I believe it in fact to have been, but in appearance it was white, except for some small spots of pale black ("blue") on the right side of the head and on the hips. The head pigmentation extended as a "faint pigmented streak" on to "the iris of each eye." The mother of this animal was blue, the father cream (which is recessive to blue), but he also transmitted albinism. He can not have transmitted blue, since that is dominant to cream. Undoubtedly, then, the egg from which this individual developed transmitted color $(C)$ and blue $(E)$ which lie in different chromosomes. But the father transmitted albinism $(c)$ and cream $(e)$, which are recessive allelomorphs of $C$ and $E$ respectively. Evidently it was the maternal chromosome bearing $C$ which was lost from the greater part of the ectoderm of the embryo, since no other loss would have produced an uncolored coat and eye. Whether or not $E$ was lost in the same regions can not be determined, but since all colored areas were blue, not cream, it is evident that wherever $C$ was retained, $E$ was retained also.

The peculiar individual was a female and produced three young, all albinos as I recall, by an albino sire, before her untimely death. It can not be stated, therefore, whether the germ-cells were heterozygous in nature or were like the greater part of the coat, pure albino, inherited from the sire alone. Certainly none of the three developing ova transmitted the mosaic condition found in the mother. It seems probable, though it is regrettably unverifiable, that no young mottled like the mother would have been obtained, had we been able to obtain a much larger number of young. 


\section{BIBLIOGRAPHY.}

Castle, W. E. 1914. The nature of size factors as indicated by a study of correlation. Carnegie Inst. Wash. Pub. No. 196, pp. 51-55.

1921. On a method of estimating the number of genetic factors concerned in cases of blending inheritance. Science, 54, pp. 93-96, 223.

in collaboration with H. E. Walter, R. C. Mullenix, and S. Cobr. 1909. Studies of inheritance in rabbits. Carnegie Inst. Wash. Pub. No. 114, 70 pp., 4 pl.

Davenport, C. B. 1917. Inheritance of stature. Genetics, 2, 313-389.

Galton, F. 1889. Natural inheritance. $259 \mathrm{pp}$.

HaRvey, Ethel B. 1920. A review of the chromosome numbers in the metazoa II. Jour. Morph., 34, 1-68.

Hoshino, Y. 1915. On the inheritance of the flowering time in peas and rice. Jour. Col. Agr., Tohoku Imp. Univ., 6.

LANG, A. 1910. Die Erblichkeitsverhältnisse der Ohrenlänge der Kaninchen, etc. \%eit. f. ind. Abst. u. Vererbungslehre, 4, 1-23.

MacDowell, E. C. 1914. Size inheritance in rabbits. Carnegie Inst. Wash. Pub. No. 196, pp. 1-49, 9 figs.

Miller, G. S. 1912. Catalogue of the mammals of Western Europe. 1019 pp. British Museum, London.

Punnett, R. C. 1912. Inheritance of coat-colour in rabbits. Jour. Genetics, 2, pp. 221-238, pl. 12-14.

and P. G. BAILEY. 1914. On inheritance of weight in poultry. Jour. Genetics, 4, 23-39, pl. IV.

1915. Further experiments on the inheritance of coat-colour in rabbits. Jour. Genetics, 5, pp. 37-50.

- 1918. Genetic studies in rabbits. I. On the inheritance of weight. Jour. Genetics 8, 1-25.

IVrint, Sewall. 1918. On the nature of size factors Genetics, 3, 367-374. 
56 

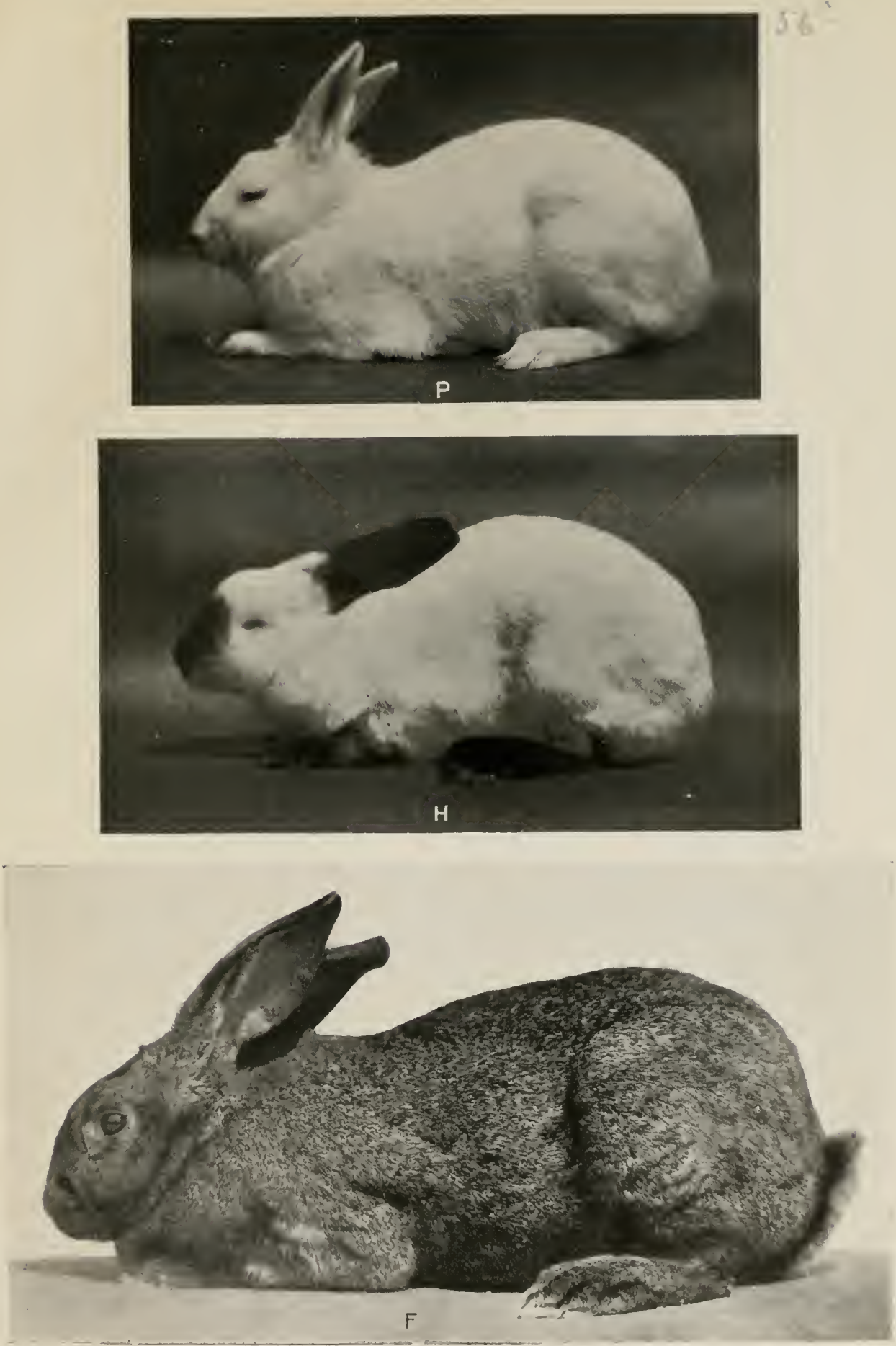

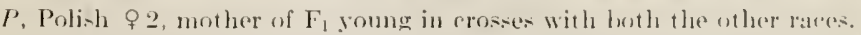

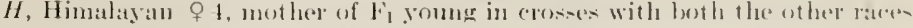

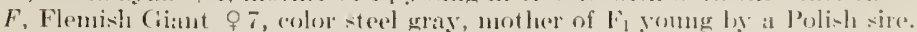
The redative size is eorrectly shown, exerett in the rase of the polish inlividual, which is a litile tou litrge. 


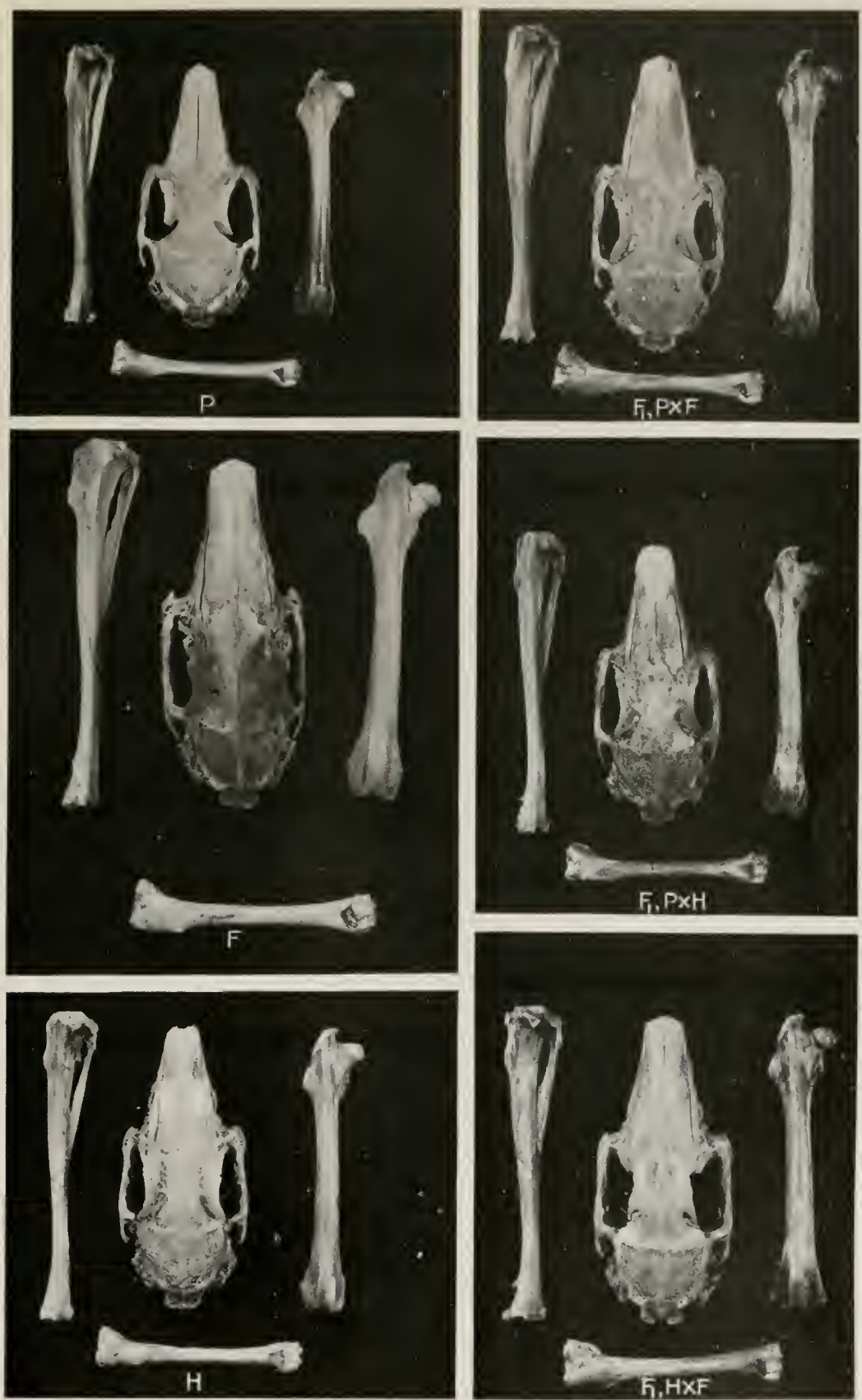

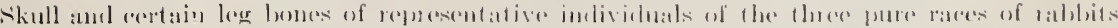

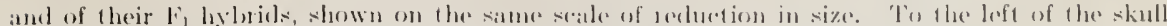

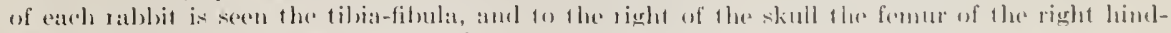
leg. Below the skull is seroll the right humertas.

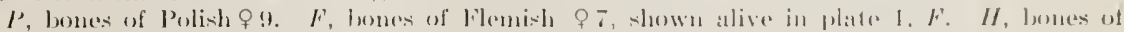

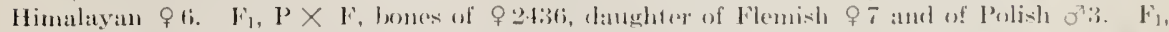

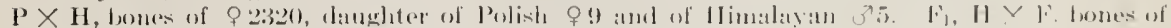

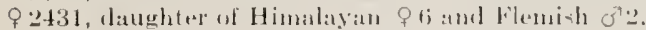




QH Castle, William Ernest

431 Genetic studies

C374

Biolled.

PLEASE DO NOT REMOVE

CARDS OR SLIPS FROM THIS POCKET

UNIVERSITY OF TORONTO LIBRARY 
